\title{
Antibiotics for exacerbations of chronic obstructive pulmonary disease
}

\author{
Vollenweider, Daniela J ; Jarrett, Harish ; Steurer-Stey, Claudia A ; Garcia-Aymerich, Judith ; Puhan, \\ Milo A
}

\begin{abstract}
BACKGROUND: Many patients with an exacerbation of chronic obstructive pulmonary disease $(\mathrm{COPD})$ are treated with antibiotics. However, the value of antibiotics remains uncertain as systematic reviews and clinical trials have shown conflicting results. OBJECTIVES: To assess the effects of antibiotics in the management of acute COPD exacerbations on treatment failure as observed between seven days and one month after treatment initiation (primary outcome) and on other patient-important outcomes (mortality, adverse events, length of hospital stay). SEARCH METHODS: We searched the Cochrane Central Register of Controlled Trials (CENTRAL), MEDLINE, EMBASE and other electronically available databases up to September 2012. SELECTION CRITERIA: Randomised controlled trials (RCTs) in people with acute COPD exacerbations comparing antibiotic therapy and placebo with a follow-up of at least seven days. DATA COLLECTION AND ANALYSIS: Two review authors independently screened references and extracted data from trial reports. We kept the three groups of outpatients, inpatients and patients admitted to the intensive care unit (ICU) separate for benefit outcomes and mortality because we considered them to be clinically too different to be summarised in one group. We considered outpatients to have a mild to moderate exacerbation, inpatients to have a severe exacerbation and ICU patients to have a very severe exacerbation. Where outcomes or study details were not reported we requested missing data from the authors of the primary studies. We calculated pooled risk ratios (RR) for treatment failure, Peto odds ratios (OR) for rare events (mortality and adverse events) and weighted mean differences (MD) for continuous outcomes using fixed-effect models. We used GRADE to assess the quality of the evidence. MAIN RESULTS: Sixteen trials with 2068 participants were included. In outpatients (mild to moderate exacerbations), there was evidence of low quality that antibiotics did statistically significantly reduce the risk for treatment failure between seven days and one month after treatment initiation (RR $0.75 ; 95 \%$ CI 0.60 to $0.94 ; \mathrm{I}(2)=35 \%$ ) but they did not significantly reduce the risk when the meta-analysis was restricted to currently available drugs (RR 0.80; 95\% CI 0.63 to 1.01 ; $\mathrm{I}(2)=33 \%$ ). Evidence of high quality showed that antibiotics statistically significantly reduced the risk of treatment failure in inpatients with severe exacerbations (ICU not included) (RR 0.77; 95\% CI 0.65 to $0.91 ; \mathrm{I}(2)=47 \%$ ) regardless of whether restricted to current drugs. The only trial with 93 patients admitted to the ICU showed a large and statistically significant effect on treatment failure (RR 0.19; $95 \%$ CI 0.08 to 0.45 ; high-quality evidence).Evidence of low-quality from four trials in inpatients showed no effect of antibiotics on mortality (Peto OR 1.02; 95\% CI 0.37 to 2.79). High-quality evidence from one trial showed a statistically significant effect on mortality in ICU patients (Peto OR 0.21; 95\% CI 0.06 to 0.72). Length of hospital stay (in days) was similar in the antibiotics and placebo groups except for the ICU study where antibiotics statistically significantly reduced length of hospital stay (mean difference -9.60 days; $95 \%$ CI -12.84 to -6.36 days). One trial showed no effect of antibiotics on re-exacerbations between two and six weeks after treatment initiation. Only one trial $(\mathrm{N}=35)$ reported health-related quality of life but did not show a statistically significant difference between the treatment and control group.Evidence of moderate quality showed that the overall incidence of adverse events was higher in the antibiotics groups (Peto OR 1.53; $95 \%$ CI 1.03 to 2.27). Patients treated with antibiotics experienced statistically significantly more diarrhoea based on three trials (Peto OR 2.62; 95\% CI 1.11 to 6.17; highquality evidence). AUTHORS' CONCLUSIONS: Antibiotics for COPD exacerbations showed large and consistent beneficial effects across outcomes of patients admitted to an ICU. However, for outpatients and
\end{abstract}


inpatients the results were inconsistent. The risk for treatment failure was significantly reduced in both inpatients and outpatients when all trials (1957 to 2012) were included but not when the analysis for outpatients was restricted to currently used antibiotics. Also, antibiotics had no statistically significant effect on mortality and length of hospital stay in inpatients and almost no data on patient-reported outcomes exist. These inconsistent effects call for research into clinical signs and biomarkers that help identify patients who benefit from antibiotics and patients who experience no effect, and in whom downsides of antibiotics (side effects, costs and multi-resistance) could be avoided.

DOI: https://doi.org/10.1002/14651858.CD010257

Posted at the Zurich Open Repository and Archive, University of Zurich

ZORA URL: https://doi.org/10.5167/uzh-73570

Journal Article

Published Version

Originally published at:

Vollenweider, Daniela J; Jarrett, Harish; Steurer-Stey, Claudia A; Garcia-Aymerich, Judith; Puhan, Milo A (2012). Antibiotics for exacerbations of chronic obstructive pulmonary disease. Cochrane Database of Systematic Reviews, 12:CD010257.

DOI: https://doi.org/10.1002/14651858.CD010257 


\section{(E) Cochrane Library}

Cochrane Database of Systematic Reviews

\section{Antibiotics for exacerbations of chronic obstructive pulmonary disease (Review)}

Vollenweider DJ, Jarrett H, Steurer-Stey CA, Garcia-Aymerich J, Puhan MA

Vollenweider DJ, Jarrett H, Steurer-Stey CA, Garcia-Aymerich J, Puhan MA.

Antibiotics for exacerbations of chronic obstructive pulmonary disease.

Cochrane Database of Systematic Reviews 2012, Issue 12. Art. No.: CD010257.

DOI: 10.1002/14651858.CD010257.

www.cochranelibrary.com 
TABLE OF CONTENTS

HEADER

ABSTRACT

PLAIN LANGUAGE SUMMARY . . . . . . . . . . . . . . . . . . . . . . . . . . . . . . . . . . . . . .

SUMMARY OF FINDINGS FOR THE MAIN COMPARISON . . . . . . . . . . . . . . . . . . . . . . . 4

BACKGROUND . . . . . . . . . . . . . . . . . . . . . . . . . . . . . . . . . . . . . 7

OBJECTIVES . . . . . . . . . . . . . . . . . . . . . . . . . . . . . . . . . . . . . . . 47

METHODS . . . . . . . . . . . . . . . . . . . . . . . . . . . . . . . . . . . . . . 7

RESULTS . . . . . . . . . . . . . . . . . . . . . . . . . . . . . . . . . . 9

Figure 1. . . . . . . . . . . . . . . . . . . . . . . . . . . . . . . . . . . . . . 10

Figure 2. . . . . . . . . . . . . . . . . . . . . . . . . . . . . . . . . . . . . . 11

Figure 3. . . . . . . . . . . . . . . . . . . . . . . . . . . . . . . . . . . . . . 12

Figure $4 . \quad$. . . . . . . . . . . . . . . . . . . . . . . . . . . . . . . . . . . . . 13

Figure 5. . . . . . . . . . . . . . . . . . . . . . . . . . . . . . . . . . . . . . 15

Figure 6. . . . . . . . . . . . . . . . . . . . . . . . . . . . . . . . . . . . . . 16

DISCUSSION . . . . . . . . . . . . . . . . . . . . . . . . . . . . . . . . . . . . . 17

AUTHORS' CONCLUSIONS . . . . . . . . . . . . . . . . . . . . . . . . . . . . . . . . 18

ACKNOWLEDGEMENTS . . . . . . . . . . . . . . . . . . . . . . . . . . . . . . . . . . . 19

REFERENCES . . . . . . . . . . . . . . . . . . . . . . . . . . . . . . . . . . . . . . 19

CHARACTERISTICS OF STUDIES . . . . . . . . . . . . . . . . . . . . . . . . . . . . . . . . . . . . . . .

DATA AND ANALYSES . . . . . . . . . . . . . . . . . . . . . . . . . . . . . . . . . . 48

Analysis 1.1. Comparison 1 Antibiotics versus placebo, Outcome 1 Treatment failure up to 4 weeks (no resolution or deterioration after trial medication of any duration or death when explicitly stated due to exacerbation or additional course of antibiotics).

Analysis 1.2. Comparison 1 Antibiotics versus placebo, Outcome 2 Treatment failure within 4 weeks - current drugs only. 51

Analysis 1.3. Comparison 1 Antibiotics versus placebo, Outcome 3 Adverse events. . . . . . . . . . . . . . . . 52

Analysis 1.4. Comparison 1 Antibiotics versus placebo, Outcome 4 All-cause mortality. . . . . . . . . . . . . . . 53

Analysis 1.5. Comparison 1 Antibiotics versus placebo, Outcome 5 Duration of hospital stay (days). . . . . . . . $\quad 54$

Analysis 1.6. Comparison 1 Antibiotics versus placebo, Outcome 6 Improvement in dyspnoea measured at the end of the study period.

Analysis 1.7. Comparison 1 Antibiotics versus placebo, Outcome 7 Health-related quality of life or functional status measures.

Analysis 1.8. Comparison 1 Antibiotics versus placebo, Outcome 8 Re-exacerbations within $\geq 2$ to 6 weeks since beginning of index exacerbation (rates).

Analysis 1.9. Comparison 1 Antibiotics versus placebo, Outcome 9 Days off work. . . . . . . . . . . . . 57

ADDITIONAL TABLES . . . . . . . . . . . . . . . . . . . . . . . . . . . . . . . . . . 57

APPENDICES . . . . . . . . . . . . . . . . . . . . . . . . . . . . . . . . . . . . . 59

CONTRIBUTIONS OF AUTHORS . . . . . . . . . . . . . . . . . . . . . . . . . . . . . . . . . . . . . 60

DECLARATIONS OF INTEREST . . . . . . . . . . . . . . . . . . . . . . . . . . . . . . . . . . 60

DIFFERENCES BETWEEN PROTOCOL AND REVIEW . . . . . . . . . . . . . . . . . . . . . . 61

INDEX TERMS . . . . . . . . . . . . . . . . . . . . . . . . . . . . . . . . . . . . . 61

Antibiotics for exacerbations of chronic obstructive pulmonary disease (Review)

Copyright $\odot 2012$ The Cochrane Collaboration. Published by John Wiley \& Sons, Ltd. 


\title{
[Intervention Review] \\ Antibiotics for exacerbations of chronic obstructive pulmonary disease
}

\author{
Daniela J Vollenweider ${ }^{1}$, Harish Jarrett ${ }^{2}$, Claudia A Steurer-Stey ${ }^{3}$, Judith Garcia-Aymerich ${ }^{4,5,6,7}$, Milo A Puhan ${ }^{8}$ \\ ${ }^{1}$ General Internal Medicine, John Hopkins University, Baltimore, MD, USA. ${ }^{2}$ Department of Internal Medicine, Temple University \\ Hospital, Philadelphia, USA. ${ }^{3}$ Institute of General Practice, University of Zurich, Zurich, Switzerland. ${ }^{4}$ Centre for Research in Envi- \\ ronmental Epidemiology (CREAL), Barcelona, Spain. ${ }^{5}$ Hospital del Mar Research Institute (IMIM), Barcelona, Spain. ${ }^{6}$ CIBER Epi- \\ demiología y Salud Pública (CIBERESP), Barcelona, Spain. ${ }^{7}$ Department of Experimental and Health Sciences, University of Pompeu \\ Fabra, Barcelona, Spain. ${ }^{8}$ Epidemiology, Johns Hopkins Bloomberg School of Public Health, Baltimore, MD, USA
}

Contact address: Daniela J Vollenweider, General Internal Medicine, John Hopkins University, Baltimore, MD, 21287, USA. danivollenweider@yahoo.de,dpuhanv1@jhmi.edu.

Editorial group: Cochrane Airways Group.

Publication status and date: New, published in Issue 12, 2012.

Citation: Vollenweider DJ, Jarrett H, Steurer-Stey CA, Garcia-Aymerich J, Puhan MA. Antibiotics for exacerbations of chronic obstructive pulmonary disease. Cochrane Database of Systematic Reviews 2012, Issue 12. Art. No.: CD010257. DOI: 10.1002/14651858.CD010257.

Copyright (C) 2012 The Cochrane Collaboration. Published by John Wiley \& Sons, Ltd.

\begin{abstract}
A B S T R A C T
Background

Many patients with an exacerbation of chronic obstructive pulmonary disease (COPD) are treated with antibiotics. However, the value of antibiotics remains uncertain as systematic reviews and clinical trials have shown conflicting results.
\end{abstract}

\section{Objectives}

To assess the effects of antibiotics in the management of acute COPD exacerbations on treatment failure as observed between seven days and one month after treatment initiation (primary outcome) and on other patient-important outcomes (mortality, adverse events, length of hospital stay).

\section{Search methods}

We searched the Cochrane Central Register of Controlled Trials (CENTRAL), MEDLINE, EMBASE and other electronically available databases up to September 2012.

\section{Selection criteria}

Randomised controlled trials (RCTs) in people with acute COPD exacerbations comparing antibiotic therapy and placebo with a follow-up of at least seven days.

\section{Data collection and analysis}

Two review authors independently screened references and extracted data from trial reports. We kept the three groups of outpatients, inpatients and patients admitted to the intensive care unit (ICU) separate for benefit outcomes and mortality because we considered them to be clinically too different to be summarised in one group. We considered outpatients to have a mild to moderate exacerbation, inpatients to have a severe exacerbation and ICU patients to have a very severe exacerbation. Where outcomes or study details were not reported we requested missing data from the authors of the primary studies. We calculated pooled risk ratios (RR) for treatment failure, Peto odds ratios (OR) for rare events (mortality and adverse events) and weighted mean differences (MD) for continuous outcomes using fixed-effect models. We used GRADE to assess the quality of the evidence.

Antibiotics for exacerbations of chronic obstructive pulmonary disease (Review)

Copyright $\odot 2012$ The Cochrane Collaboration. Published by John Wiley \& Sons, Ltd. 


\section{Main results}

Sixteen trials with 2068 participants were included. In outpatients (mild to moderate exacerbations), there was evidence of low quality that antibiotics did statistically significantly reduce the risk for treatment failure between seven days and one month after treatment initiation (RR $0.75 ; 95 \%$ CI 0.60 to $0.94 ; \mathrm{I}^{2}=35 \%$ ) but they did not significantly reduce the risk when the meta-analysis was restricted to currently available drugs (RR $0.80 ; 95 \%$ CI 0.63 to $1.01 ; \mathrm{I}^{2}=33 \%$ ). Evidence of high quality showed that antibiotics statistically significantly reduced the risk of treatment failure in inpatients with severe exacerbations (ICU not included) (RR 0.77 ; $95 \%$ CI 0.65 to $0.91 ; \mathrm{I}^{2}=47 \%$ ) regardless of whether restricted to current drugs. The only trial with 93 patients admitted to the ICU showed a large and statistically significant effect on treatment failure (RR $0.19 ; 95 \%$ CI 0.08 to 0.45 ; high-quality evidence).

Evidence of low-quality from four trials in inpatients showed no effect of antibiotics on mortality (Peto OR 1.02 ; $95 \%$ CI 0.37 to 2.79). High-quality evidence from one trial showed a statistically significant effect on mortality in ICU patients (Peto OR $0.21 ; 95 \%$ CI 0.06 to 0.72 ). Length of hospital stay (in days) was similar in the antibiotics and placebo groups except for the ICU study where antibiotics statistically significantly reduced length of hospital stay (mean difference -9.60 days; 95\% CI -12.84 to -6.36 days). One trial showed no effect of antibiotics on re-exacerbations between two and six weeks after treatment initiation. Only one trial $(\mathrm{N}=35)$ reported health-related quality of life but did not show a statistically significant difference between the treatment and control group.

Evidence of moderate quality showed that the overall incidence of adverse events was higher in the antibiotics groups (Peto OR 1.53; 95\% CI 1.03 to 2.27). Patients treated with antibiotics experienced statistically significantly more diarrhoea based on three trials (Peto OR 2.62; $95 \%$ CI 1.11 to 6.17 ; high-quality evidence).

\section{Authors' conclusions}

Antibiotics for COPD exacerbations showed large and consistent beneficial effects across outcomes of patients admitted to an ICU. However, for outpatients and inpatients the results were inconsistent. The risk for treatment failure was significantly reduced in both inpatients and outpatients when all trials (1957 to 2012) were included but not when the analysis for outpatients was restricted to currently used antibiotics. Also, antibiotics had no statistically significant effect on mortality and length of hospital stay in inpatients and almost no data on patient-reported outcomes exist. These inconsistent effects call for research into clinical signs and biomarkers that help identify patients who benefit from antibiotics and patients who experience no effect, and in whom downsides of antibiotics (side effects, costs and multi-resistance) could be avoided.

\section{PLAIN LANGUAGE SUMMARY}

\section{Antibiotics for exacerbations of chronic obstructive pulmonary disease}

Chronic obstructive pulmonary disease (COPD) is a chronic condition, often caused by smoking, which affects the passage of air in and out of the lungs. Exacerbations of COPD are defined as a sustained worsening of the patient's symptoms from their usual stable state and commonly reported symptoms are worsening breathlessness, cough, increased sputum production and change in sputum colour. Antibiotics are frequently prescribed for exacerbations in patients with COPD although the cause of exacerbations is often difficult to determine (viral, bacterial, environmental). We did this systematic review to find out if there is good evidence for using antibiotics for exacerbations of COPD and if benefits of taking antibiotics in individuals outweigh potential harms for individual patients and the risks of multi-resistant bacteria to the population.

We found 16 randomised studies compared antibiotics with placebo in a total of 2068 COPD patients who presented with a wide range of severities of exacerbations. Analyses showed that antibiotics reduce treatment failures (no improvement) compared with placebo in hospitalised patients with severe exacerbations. In outpatients with mild to moderate exacerbations, the evidence is more unclear because analyses showed a reduction of treatment failure when all studies and antibiotics were considered, but analyses did not suggest such an effect when they were restricted to antibiotics in current use. Length of hospital stay and mortality were not reduced by antibiotics in hospitalised patients except for those who needed treatment on the intensive care unit. Patients treated with antibiotics experienced diarrhoea twice as often as patients receiving placebo. Severity of underlying COPD could not be compared across trials because lung function and other parameters were reported inconsistently between trials.

Current evidence shows that antibiotics reduce treatment failures in patients who are hospitalised for the treatment of a COPD exacerbation, and to a lesser extent in outpatients. Mortality is only reduced by antibiotics in patients with very severe exacerbations who need treatment in the intensive care unit. The rather small and inconsistent effects of antibiotics on treatment failure suggest that antibiotics are effective in some patients but not in all inpatients and outpatients. Future high-quality studies should explore how 
antibiotic therapy may be targeted towards patients who benefit by using clinical signs (e.g. purulent sputum) or biomarkers at the time when patients present to the primary care doctor or emergency department. 


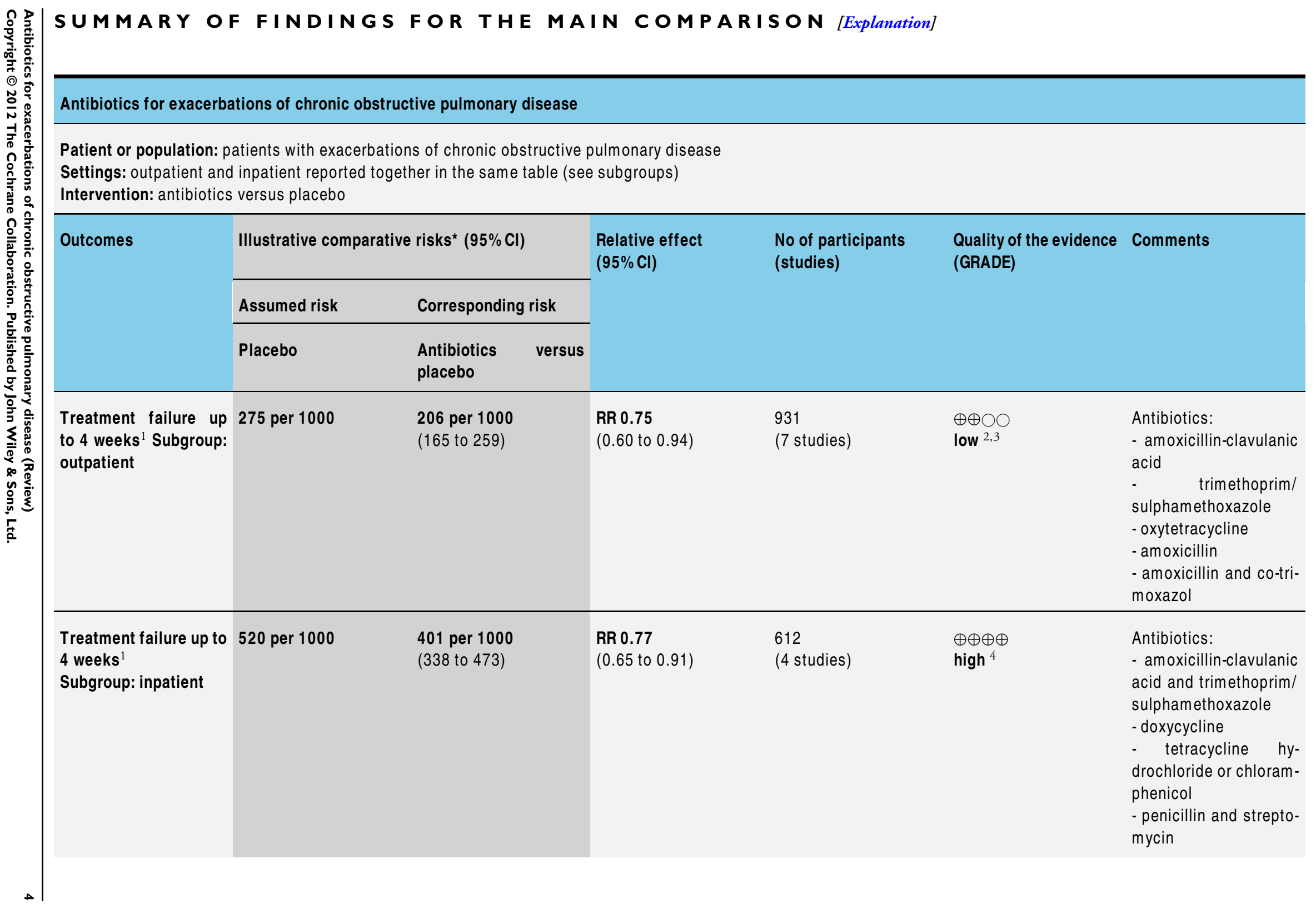




\begin{tabular}{|c|c|c|c|c|c|c|}
\hline $\begin{array}{l}\text { Treatment failure up to } \\
4 \text { weeks }{ }^{1} \\
\text { Subgoup: ICU }\end{array}$ & 565 per 1000 & $\begin{array}{l}107 \text { per } 1000 \\
(45 \text { to } 254)\end{array}$ & $\begin{array}{l}\text { RR } 0.19 \\
(0.08 \text { to } 0.45)\end{array}$ & $\begin{array}{l}93 \\
\text { (1 study) }\end{array}$ & $\begin{array}{l}\oplus \oplus \oplus \oplus \\
\text { high }\end{array}$ & $\begin{array}{l}\text { Antibiotics: } \\
\text { - ofloxacine }\end{array}$ \\
\hline $\begin{array}{l}\text { All-cause mortality } \\
\text { Subgroup: inpatients }\end{array}$ & 35 per 1000 & $\begin{array}{l}36 \text { per } 1000 \\
(13 \text { to } 92)\end{array}$ & $\begin{array}{l}\text { OR } 1.02 \\
\text { (0.37 to } 2.79)\end{array}$ & $\begin{array}{l}531 \\
\text { (4 studies) }\end{array}$ & $\begin{array}{l}\oplus \oplus \bigcirc \bigcirc \\
\text { low } 5,6\end{array}$ & $\begin{array}{l}\text { Antibiotics: } \\
\text { - tetracycline hy- } \\
\text { drochloride or chloram- } \\
\text { phenicol } \\
\text { - penicillin and strepto- } \\
\text { mycin } \\
\text { - chloramphenicol } \\
\text { - doxycycline }\end{array}$ \\
\hline $\begin{array}{l}\text { All-cause mortality } \\
\text { Subgroup: ICU }\end{array}$ & 217 per 1000 & $\begin{array}{l}55 \text { per } 1000 \\
(16 \text { to } 167)\end{array}$ & $\begin{array}{l}\text { OR } 0.21 \\
(0.06 \text { to } 0.72)\end{array}$ & $\begin{array}{l}93 \\
\text { (1 study) }\end{array}$ & $\begin{array}{l}\oplus \oplus \oplus \oplus \\
\text { high }^{7}\end{array}$ & $\begin{array}{l}\text { Antibiotics: } \\
\text { - ofloxacine }\end{array}$ \\
\hline $\begin{array}{l}\text { Adverse events - diar- } \\
\text { rhoea }\end{array}$ & 18 per 1000 & $\begin{array}{l}45 \text { per } 1000 \\
(19 \text { to } 99)\end{array}$ & $\begin{array}{l}\text { OR } 2.62 \\
\text { (1.11 to } 6.17)\end{array}$ & $\begin{array}{l}698 \\
\text { (3 studies) }\end{array}$ & $\begin{array}{l}\oplus \oplus \oplus \oplus \\
\text { high }\end{array}$ & $\begin{array}{l}\text { Antibiotics: } \\
\text { - amoxicillin-clavulanic } \\
\text { acid } \\
\text { - amoxicillin } \\
\text { - ofloxacine }\end{array}$ \\
\hline $\begin{array}{l}\text { Adverse events - over- } \\
\text { all (adverse events not } \\
\text { separated) }\end{array}$ & 74 per 1000 & $\begin{array}{l}109 \text { per } 1000 \\
(76 \text { to } 154)\end{array}$ & $\begin{array}{l}\text { OR } 1.53 \\
\text { (1.03 to } 2.27)\end{array}$ & $\begin{array}{l}1243 \\
\text { (5 studies) }\end{array}$ & $\begin{array}{l}\oplus \oplus \oplus \bigcirc \\
\text { moderate } 8\end{array}$ & $\begin{array}{l}\text { Antibiotics: } \\
\text { - amoxicillin-clavulanic } \\
\text { acid } \\
\text { - doxycycline } \\
\text { - amoxicillin } \\
\text { - ofloxacine }\end{array}$ \\
\hline
\end{tabular}

*The basis for the assumed risk (e.g. the median control group risk across studies) is provided in footnotes. The corresponding risk (and its $95 \%$ confidence interval) is based on the assumed risk in the comparison group and the relative effect of the intervention (and its $95 \% \mathrm{Cl}$ ).

$\mathrm{Cl}$ : confidence interval; ICU: intensive care unit; OR: odds ratio; RR: risk ratio

GRADE Working Group grades of evidence

High quality: Further research is very unlikely to change our confidence in the estimate of effect.

Moderate quality: Further research is likely to have an important impact on our confidence in the estimate of effect and may change the estimate.

Low quality: Further research is very likely to have an important impact on our confidence in the estimate of effect and is likely to change the estimate. 
${ }^{1}$ no resolution or deterioration after trial medication of any duration or death when explicitly stated due to exacerbation or additional course of antibiotics.

2 (- 1 inconsistency). Discrepancy between the statistical significance of the meta-analysis that includes all trials (RR 0.75 $95 \% \mathrm{Cl} 0.60$ to 0.94 ) vs. the meta-analysis that is restricted to currently used drugs (amoxicillin-clavulanic acid, trimethoprim/ sulphamethoxazole, doxycycline, penicillin; RR $0.80 ; 95 \% \mathrm{Cl} 0.63$ to 1.01 ).

3 (-1 limitations). For one trial (Blasi) not all results are available.

${ }^{4}$ (no downgrading). The heterogeneity was caused by two small trials that contribute only $14 \%$ to the pooled estimate. Two larger trials have the most weight in the meta-analysis and show almost identical point estimates, therefore we did not downgrade for inconsistency.

${ }^{5}(-1$ inconsistency). Substantial heterogeneity across trials with the largest trial showing an increase in mortality and the three small trials suggesting a decrease in mortality.

${ }^{6}(-1$ imprecision). Wide $95 \% \mathrm{Cl}$ that precludes any conclusion about the effects of antibiotics on mortality in inpatients.

7 (no downgrading). The $\mathrm{Cl}$ is relatively wide; however, because the upper limit of the $95 \% \mathrm{Cl}(0.72)$ as the most conservative effect estimate shows an at least moderate effect of antibiotics on mortality we did not downgrade.

${ }^{8}$ (- 1 imprecision). Lower limit of $95 \% \mathrm{Cl}$ is very close to 1.0 and it is uncertain if lower limit would be below 1.0 with additional trials. 


\section{B A C K G ROU N D}

The prescription of antibiotics for the treatment of exacerbations in patients with chronic obstructive pulmonary disease (COPD) has been, and continues to be, controversial. This controversy is largely based upon data suggesting that only about half of the exacerbations are of bacterial origin while other causes include viral infections or environmental irritants (Patel 2002; Seemungal 2001; Sethi 2004). One study by Bafadhel 2011 suggested that most exacerbations can be categorised as either bacteria-predominant, eosinophil-predominant, virus-predominant and pauci-inflammatory and thus may be susceptible to antibiotics or corticosteroids or, in the future, to newly developed antiviral drugs.

Antibiotics are widely prescribed (Jones 2008; Pretto 2012). Reasons for using antibiotics include the belief that the origin of an exacerbation is most likely to be a bacterial infection but also to 'be on the safe side' and prevent complications of an exacerbation such as pneumonia. Since side effects of antibiotics are mostly relatively minor, the potential benefits of antibiotics may often appear to outweigh its harms. The most important arguments against inappropriate use and overuse of antibiotics are the worldwide growing problem of multi-resistance (WHO factsheet no. 194), polypharmacy and costs. Current guidelines (GOLD 2011; NICE 2010) do not recommend antibiotics in general but recommend antibiotic therapy if all three cardinal symptoms (increased dyspnoea, sputum and cough) exist or with two of the three cardinal symptoms, if increased purulence is one of them, which may or may not be indicative of a bacterial exacerbation. However, there is currently no high-quality evidence to support this recommendation. In addition, healthcare providers may not always see that sputum and description of the patient may be unreliable.

\section{Why it is important to do this review}

There are several important reasons to conduct this systematic review. A systematic review of the literature informs patients, healthcare providers and clinical practice guideline developers in a transparent way (to minimise bias) about the effects of antibiotics on patient-important outcomes. This is important since antibiotics are likely to be perceived as beneficial in clinical practice by patients and healthcare providers because most patients recover within some weeks. However, only placebo-controlled trials can determine the cause of such recovery, which might be because of the natural recovery from exacerbations (i.e. without antibiotics), the effects of antibiotics or some other concomitant treatments such a systemic corticosteroids. Knowledge about the effects of antibiotics compared to placebo is also important to appreciate the results of the many randomised trials that compare different antibiotics. Only if antibiotics are effective at all will such headto-head trials provide useful information (Puhan 2008).

There is growing recognition that COPD is a very heterogeneous disease (Garcia-Aymerich 2011) and exacerbations are heteroge- neous events (Bafadhel 2011). This systematic review may also provide some guidance on the effects of antibiotics in different patients. Finally, systematic reviews provide useful guidance on how strong recommendations can be made for clinical practice and where more research is needed. Thus, given the uncertainties about the use of antibiotics for COPD exacerbations, this systematic review provides useful information in several respects.

This review is partly based on the protocol of a withdrawn Cochrane review on the same topic (Ram 2006) and the standard methods of the Cochrane Collaboration.

\section{O B J E C T IVES}

To assess the effects of antibiotics in the management of acute COPD exacerbations on treatment failure as observed between seven days and one month after treatment initiation (primary outcome) and on other patient-important outcomes (mortality, adverse events, length of hospital stay).

\section{METHODS}

\section{Criteria for considering studies for this review}

\section{Types of studies}

Randomised controlled trials (RCTs) using an antibiotic in the treatment group and placebo in the control group.

\section{Types of participants}

Patients with acute exacerbations of COPD (defined as a worsening of a previous stable situation with symptoms such as increased dyspnoea, increased cough, increased sputum volume or change in sputum colour).

We considered studies eligible if more than $90 \%$ of patients had a clinical (physician-based) diagnosis of COPD or, ideally, spirometrically confirmed COPD and patients were over 40 years of age. For trials with physician-based diagnosis of COPD (also chronic bronchitis in older studies) we only considered studies when over $90 \%$ of patients had a smoking history. We accepted physicianbased diagnosis of COPD because spirometry has limited value during an acute exacerbation of COPD and because restricting the systematic review to patients with spirometrically confirmed COPD would be limited to trials where patients at risk for exacerbations were enrolled in stable state and randomised when they actually suffered from an exacerbation. We excluded studies of patients with acute bronchitis, pneumonia, asthma or bronchiectasis. 


\section{Types of interventions}

Oral or intravenous antibiotics administered daily for a minimum period of at least two days. All studies using antibiotics for the prevention of exacerbations were excluded as this addresses a different question. Whether or not oral corticosteroids were used additionally was not an inclusion or exclusion criterion.

\section{Types of outcome measures}

\section{Primary outcomes}

- Treatment failure as observed between seven days and one month after treatment initiation (no resolution or deterioration of symptoms after trial medication of any duration or death when explicitly stated due to exacerbation or additional course of antibiotics or other medication).

\section{Secondary outcomes}

- Treatment failure as observed between seven and 14 days after treatment initiation.

- All-cause mortality.

- Duration of hospital admission (for inpatients).

- Admission to an intensive care unit (ICU).

- Re-exacerbations within $\geq$ two to six weeks since beginning of index exacerbation (inpatient or outpatient treatment, rates or time to event).

- Adverse events.

- Improvement in dyspnoea.

- Hospital admission.

- Health-related quality of life or functional status measures.

- Time off work.

\section{Search methods for identification of studies}

\section{Electronic searches}

We identified trials using the Cochrane Airways Group Specialised Register of trials, which is derived from systematic searches of bibliographic databases including the Cochrane Central Register of Controlled Trials (CENTRAL), MEDLINE, EMBASE, CINAHL, AMED and PsycINFO, and handsearching of respiratory journals and meeting abstracts (see Appendix 1 for further details). All records in the Specialised Register coded as 'COPD' were searched using the following terms:

- antibiotic* or penicillin* or amoxycillin or ampicillin or cefalosporin* or cefaclor or cefalexine or cephalotin or cefazolin or cefixime or cefotaxime or cefpodoxime or cephradine or ceftizoxime or ceftriaxone or cefuroxime or tetracyclin* or demeclocycline or doxycycline or minocycline or oxytetracycline or *ycline or macrolides or azithromycin or clarithromycin or dirithromycin or erythromycin or roxithromycin or telithromycin or troleandomycin or *thromycin or ( ${ }^{*}$ mycin) or fluoroquinoln* or ciprofloxacin or gatifloxacin or gemfloxacin or grepafloxacin or levofloxacin or lomefloxacin or moxifloxacin or ofloxacin or sparfloxacin or trovafloxacin or *floxacin or chloramphenicol or clindamycin or trimethoprim or sulfamethxazole or cotrimoxazole or carbapenem* or meropenem or imipenem.

A search of ClinicalTrials.gov was also conducted. Databases were searched from 2005 (their inception) to April 2012. The search from inception to 2006 is described elsewhere (Puhan 2007). There was no restriction on the language of publication.

\section{Searching other resources}

Bibliographies of each selected RCT, and other systematic reviews, were scrutinised for additional potential RCTs. Authors of identified RCTs and pharmaceutical companies producing antibiotics were contacted for other published, unpublished or ongoing studies.

\section{Data collection and analysis}

\section{Selection of studies}

Two review authors independently assessed the titles and abstracts of all identified citations without imposing any language restrictions. The review authors then independently evaluated the full text of articles that seemed potentially eligible by one of the review authors. Any disagreements were resolved by consensus with close attention to the inclusion/exclusion criteria. All studies that did not fulfil all of the criteria were excluded and their bibliographic details listed, with the reason for exclusion.

\section{Data extraction and management}

Two review authors independently abstracted data, which was double checked and entered into Review Manager 5.1 software (RevMan 2011).

\section{Assessment of risk of bias in included studies}

We assessed the risk of bias using the domain-based approach described in the Cochrane Handbook of Systematic Reviews of Interventions (Higgins 2011). The domains included an assessment of how the random sequence was generated, allocation concealment was ensured, blinding of participants and personnel and outcome assessors was applied, and whether an intention-to-treat analysis was used. Any disagreements between review authors were resolved by discussion. In addition, we used the GRADE approach to determine the quality of evidence using the standard criteria risk of bias, 
inconsistency, indirectness, imprecision and other biases (Guyatt 2011).

We generated a 'Summary of findings table' for the most important outcomes (treatment failure, all-cause mortality, overall adverse events and diarrhoea) (Summary of findings for the main comparison) and used GRADEpro software and recommendations in the Cochrane Handbook of Systematic Reviews of Interventions (Higgins 2011) to assess the quality of evidence.

\section{Measures of treatment effect}

We calculated pooled risk ratios (RR), Peto odds ratios (OR) for rare events and weighted mean differences (MD) for continuous outcomes.

In trials with two groups receiving different antibiotics, we treated these groups as one group if the effects of the two antibiotics did not differ in a statistically significant or clinically important way.

\section{Dealing with missing data}

When necessary we contacted study authors in order to obtain further information about their trials.

\section{Assessment of heterogeneity}

We kept the three groups of outpatients, inpatients and patients admitted to the ICU separate for most analyses except for adverse events because we considered them to be clinically too different to be summarised in one group. We considered outpatients to have a mild to moderate exacerbation, inpatients to have a severe exacerbation and ICU patients to have a very severe exacerbation (event-based definitions of severity of exacerbations). Within the analysis of outpatients and inpatients we used the heterogeneity $\mathrm{Chi}^{2}$ statistic to assess statistical heterogeneity and expressed it by the $\mathrm{I}^{2}$ statistic.

\section{Assessment of reporting biases}

For trials published after 1990 we tried to find the trial registration information and assessed whether all outcomes specified there were reported.

\section{Data synthesis}

We used fixed-effect models (or random-effects model if statistical heterogeneity with $\mathrm{I}^{2}>50 \%$ was observed) to calculate mean differences for continuous outcomes or inverse-variance weighted pooled RRs. For rare events and trials with similar size of treatment groups we used Peto's method to pool ORs. We also calculated number needed to treat for an additional beneficial outcome
(NNTB) and 95\% confidence interval (CI) and number needed to treat for an additional harmful outcome (NNTH). These were calculated using the following formula: NNT $=1 /$ [CER * $(1$ $\mathrm{RR})$ ] (where CER = control event rate).

\section{Subgroup analysis and investigation of heterogeneity}

As explained above, we kept as a marker of the severity of exacerbation outpatients, inpatients and patients admitted to the ICU separate for all benefit outcomes.

\section{Sensitivity analysis}

In a sensitivity analysis we restricted the analyses to trials that evaluated at least one antibiotic that is still in current use (amoxicillin-clavulanic acid, trimethoprim/sulphamethoxazole, doxycycline, penicillin).

\section{RE S U L T S}

\section{Description of studies}

\section{Results of the search}

\section{Searches to 2006}

The electronic search of the former non-Cochrane review conducted by this author team (Puhan 2007) yielded 765 references. After assessing references on the basis of title and abstract, two review authors independently scanned the full text of 35 studies of the electronic search and additional 30 studies that were identified through handsearching. Four studies were ongoing trials (ABC 2009; Fartoukh 2004; NCT00170222; NCT00255983). Thirteen studies were included (Allegra 1991; Alonso Martinez 1992; Anthonisen 1987; Berry 1960; Elmes 1957; Fear 1962; Jørgensen 1992; Manresa 1987; Nouira 2001; Petersen 1967; Pines 1968; Pines 1972; Sachs 1995).

\section{Searches from 2005 to 2012}

We identified 226 citations from the update search (2005 to 2012) of electronic databases. We retrieved 25 full texts and handsearched nine protocols on www.clinicaltrials.gov. Out of this search we identified two eligible trials (Daniels 2010; Llor 2012) and through handsearching we identified one additional trial (ABC 2009) (see Figure 1). 
Figure I. Study flow diagram.

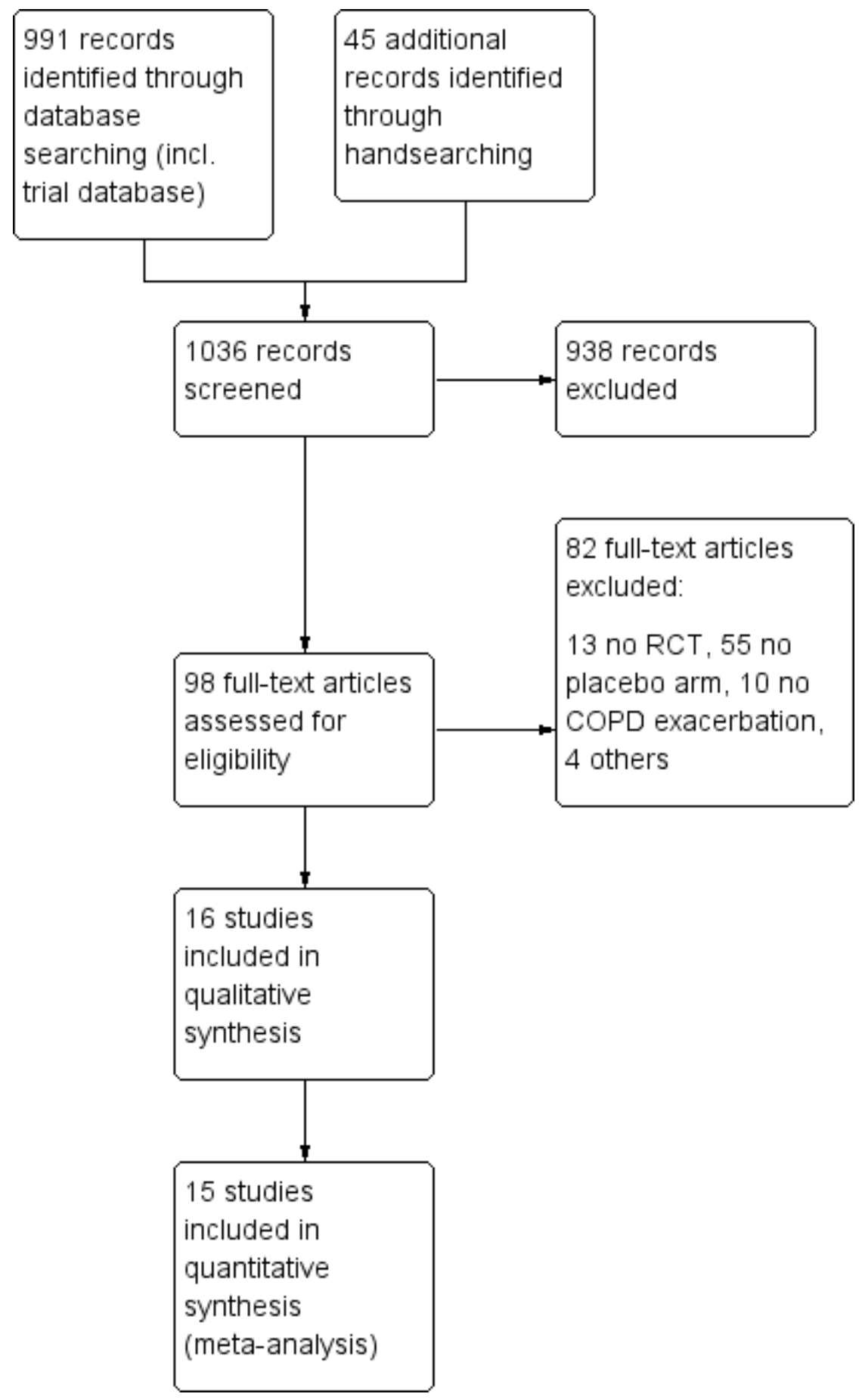




\section{Included studies}

We included 16 studies on 2068 participants. Out of the 16 included studies, nine trials included outpatients (ABC 2009; Allegra 1991; Anthonisen 1987; Berry 1960; Elmes 1957; Fear 1962; Jørgensen 1992; Llor 2012; Sachs 1995), six trials included patients admitted to a hospital (Alonso Martinez 1992; Daniels 2010; Manresa 1987; Petersen 1967; Pines 1968; Pines 1972) and one trial included patients admitted to a medical ICU (Nouira 2001). The studies were, on average, of small sample size with a range from 19 to 310 included patients. Severity of underlying COPD could not be compared across trials because lung function and other parameters were reported inconsistently between trials. Twelve trials were reported as full reports in English language journals, one trial was published in Spanish (Alonso Martinez 1992), one in Italian (Allegra 1991), one trial was reported as a conference proceeding and medical thesis (ABC 2009) and one trial was reported as a clinical letter to a major journal (Manresa 1987). One trial (Allegra 1991) only entered the analyses on adverse effects because it reported only on treatment failure within five days of treatment initiation. We made attempts to retrieve the data on treatment failure within two weeks, which was assessed but not reported (personal communication with Dr Blasi, March 2006) but the data were not made available to us. Further details on included studies are shown in the table Characteristics of included studies and a summary of the interventions across studies can be found in Table 1.

\section{Excluded studies}

We excluded most trials because they compared different types of antibiotics to each other and had no placebo arm (see Characteristics of excluded studies; Figure 1). One study was identified as an ongoing study (NCT01091493) that had just started.

\section{Risk of bias in included studies}

Overall there was relatively little risk of bias (see Figure 2). Random sequence generation, blinding of participants and personnel, and intention-to-treat analysis was correctly performed and reported by $80 \%$ of the studies. Allocation concealment and blinding of outcome assessment was correctly performed and reported by $56 \%$ of the studies.

Figure 2. Risk of bias graph: review authors' judgements about each risk of bias item presented as percentages across all included studies.

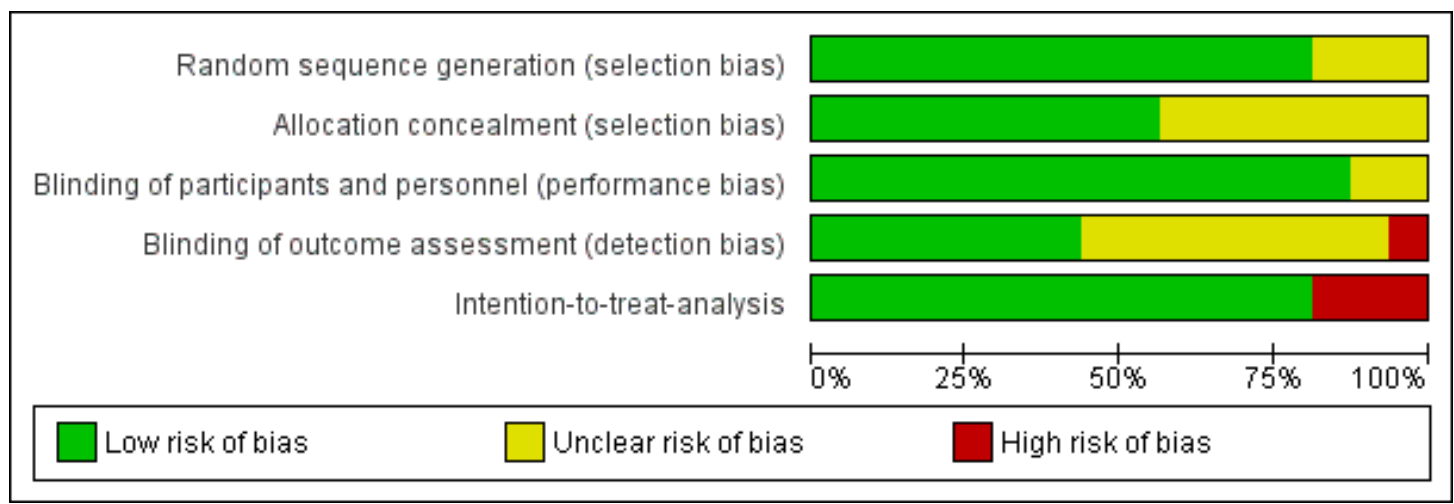

\section{Effects of interventions}

See: Summary of findings for the main comparison Antibiotics for exacerbations of chronic obstructive pulmonary disease

Primary outcome: treatment failure between seven days and one month of treatment initiation
Eleven studies with 1326 patients reported on this outcome (Figure 3). The follow-up period for these studies to assess treatment failure ranged from eight to 28 days. In some studies treatment failure outcome was patient reported (ABC 2009; Anthonisen 1987; Berry 1960; Daniels 2010; Elmes 1957; Jørgensen 1992; Sachs 1995), while in two trials it was provider 
reported (Llor 2012; Pines 1968), defined by an additional course of antibiotics (Alonso Martinez 1992; Pines 1972) or a combined end point of additional antibiotics and death (Nouira 2001). As pre-defined we analysed treatment separately for outpatients, inpatients and patients admitted to the ICU.

Figure 3. Forest plot of comparison: I Antibiotics versus placebo, outcome: I.I Treatment failure up to 4 weeks (no resolution or deterioration after trial medication of any duration or death when explicitly stated due to exacerbation or additional course of antibiotics).

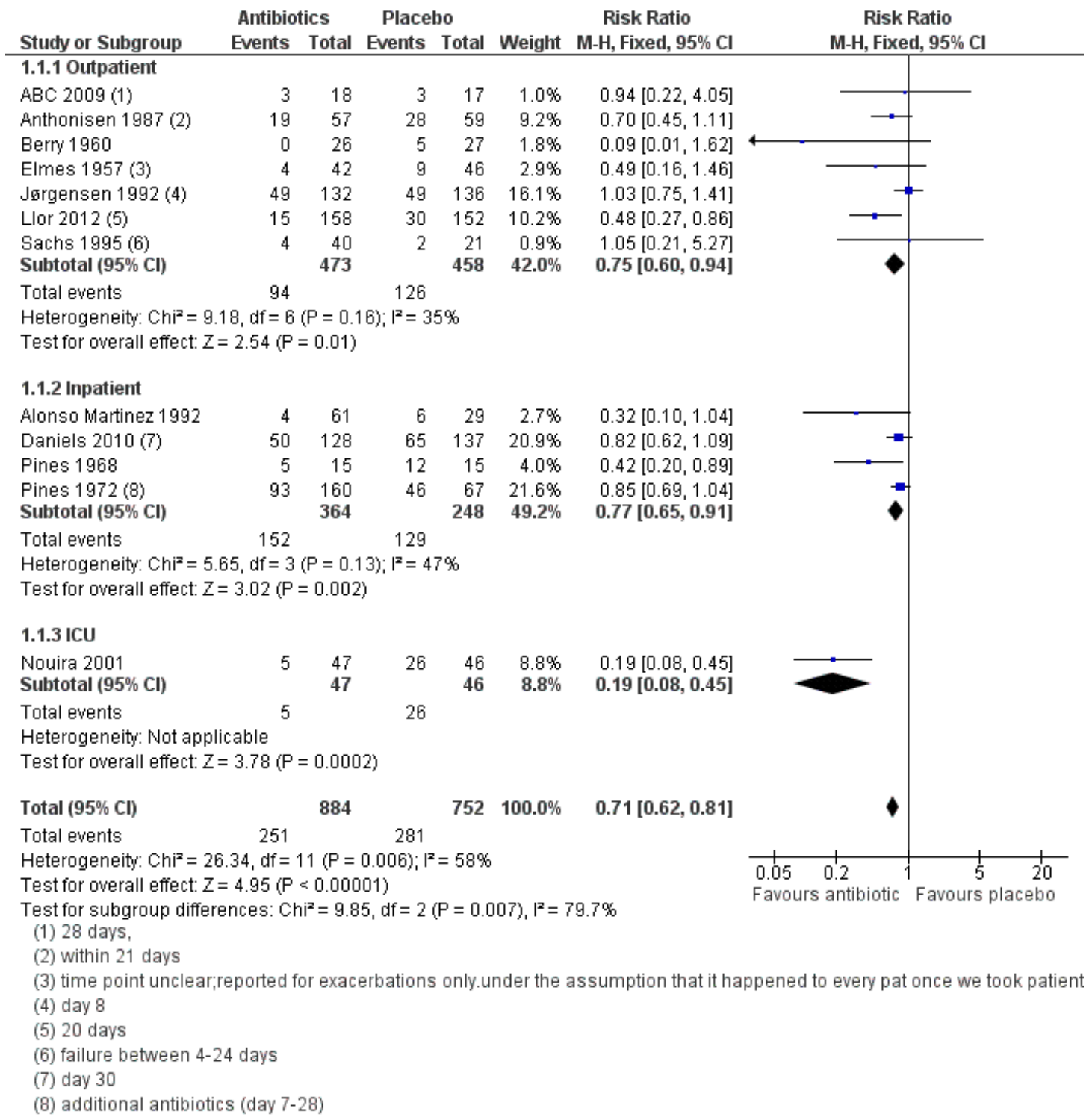

Antibiotics for exacerbations of chronic obstructive pulmonary disease (Review) 
In outpatients (seven trials; 931 participants; Figure 3) antibiotics statistically significantly reduced the risk for treatment failure (RR 0.75 ; $95 \%$ CI 0.60 to $0.94 ; \mathrm{I}^{2}=35 \%$ ) with an NNTB of 13 (95\% CI 8 to 46). Antibiotics had a statistically significant effect in inpatients (four trials; 612 participants) (RR 0.77; 95\% CI 0.65 to $0.91 ; \mathrm{I}^{2}=47 \%$ ) with an NNTB of 10 (95\% CI 6 to 45$)$. In the ICU trial with 93 participants antibiotics showed a statistically significant effect (RR 0.19 ; $95 \%$ CI 0.08 to 0.45 ) with an NNTB of 2 (95\% CI 2 to 3 ).

Restricting the analysis to currently used drugs (amoxicillin-clavulanic acid, trimethoprim/sulphamethoxazole, doxycycline, penicillin) gave a different effect compared to the unrestricted analyses for outpatients (RR 0.80; 95\% CI 0.63 to 1.01 ; Figure 4) with a non-statistically significant effect. In inpatients, the results were similar (RR 0.71; 95\% CI 0.55 to 0.92 ).

Figure 4. Forest plot of comparison: I Antibiotics versus placebo, outcome: I.2 Treatment failure within 4 weeks - current drugs only.

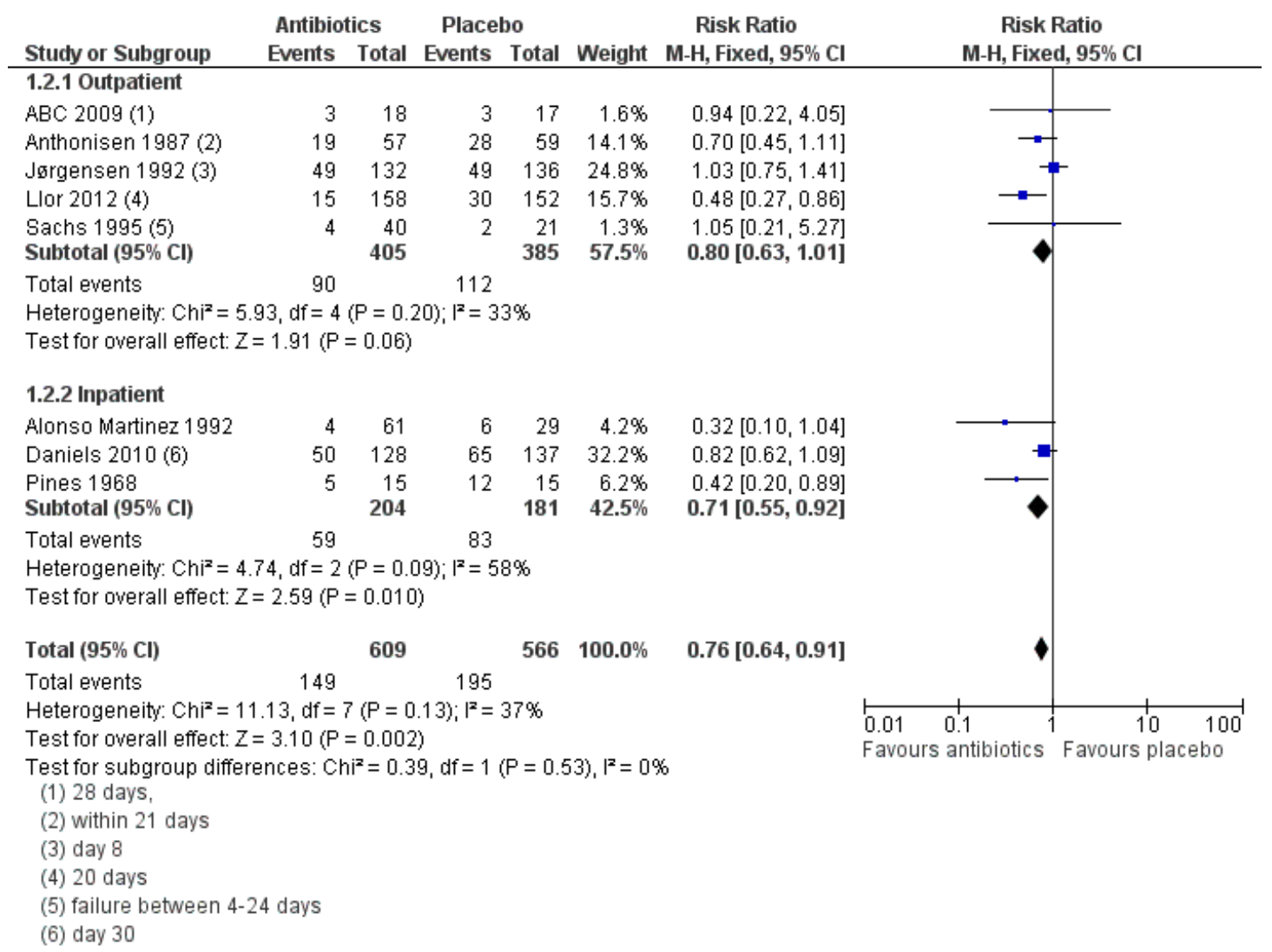

Antibiotics for exacerbations of chronic obstructive pulmonary disease (Review) 


\section{Adverse events}

The pooled analysis includes only trials that evaluated currently used antibiotics.

\section{Diarrhoea}

Three studies with 398 patients (Allegra 1991; Jørgensen 1992; Nouira 2001) provided data on the number of patients experiencing diarrhoea. Figure 5 shows that patients treated with placebo had a statistically significantly lower chance of diarrhoea compared to patients treated with antibiotics (Peto OR 2.62; 95\% CI 1.11 to 6.17 ; NNTH of $36 ; 95 \%$ CI 19 to 565 ). 
Figure 5. Forest plot of comparison: I Antibiotics versus placebo, outcome: I.3 Adverse events.

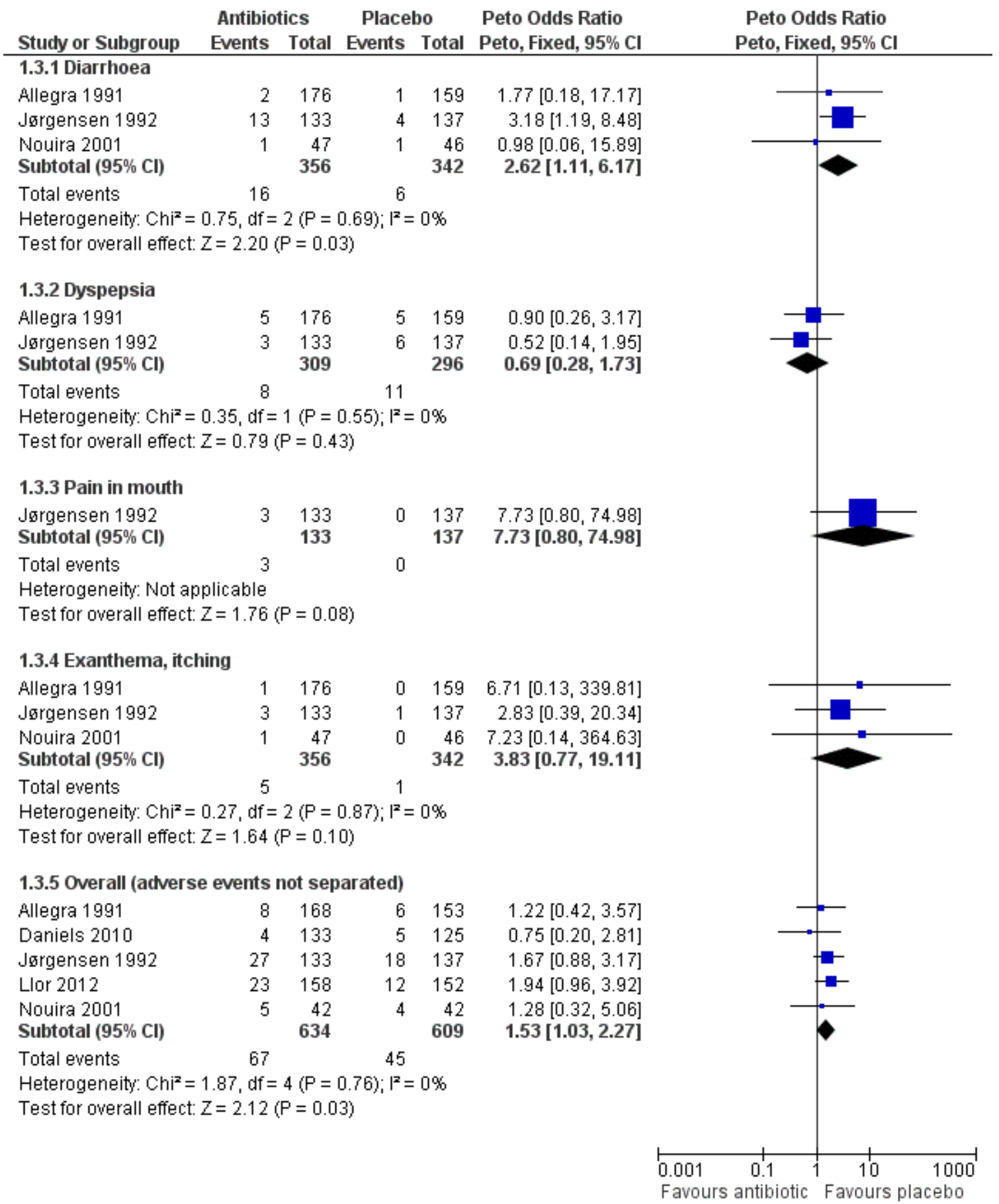




\section{Overall adverse events}

Five studies with 1243 patients (Allegra 1991; Daniels 2010; Jørgensen 1992; Llor 2012; Nouira 2001) provided data on the overall incidence of adverse events in the study groups. There were statistically significantly fewer adverse events with placebo (Peto OR 1.53 ; $95 \%$ CI 1.03 to 2.27 ; NNTH 32 ; $95 \%$ CI 16 to 10490 ). Other adverse events are shown in Figure 5.

\section{All-cause mortality}

Five trials on 624 patients, four inpatient trials (Daniels 2010; Petersen 1967; Pines 1968; Pines 1972) and one ICU trial (Nouira 2001), reported mortality. There was no statistically significant effect of antibiotics on mortality for inpatients (Peto OR 1.02; 95\% CI 0.37 to 2.79 ) but there was a statistically significant effect in ICU patients (Peto OR 0.21; $95 \%$ CI 0.06 to 0.72 ; NNTB 6 (96\% CI 3 to 24) (Figure 6).

Figure 6. Forest plot of comparison: I Antibiotics versus placebo, outcome: I.4 All-cause mortality.

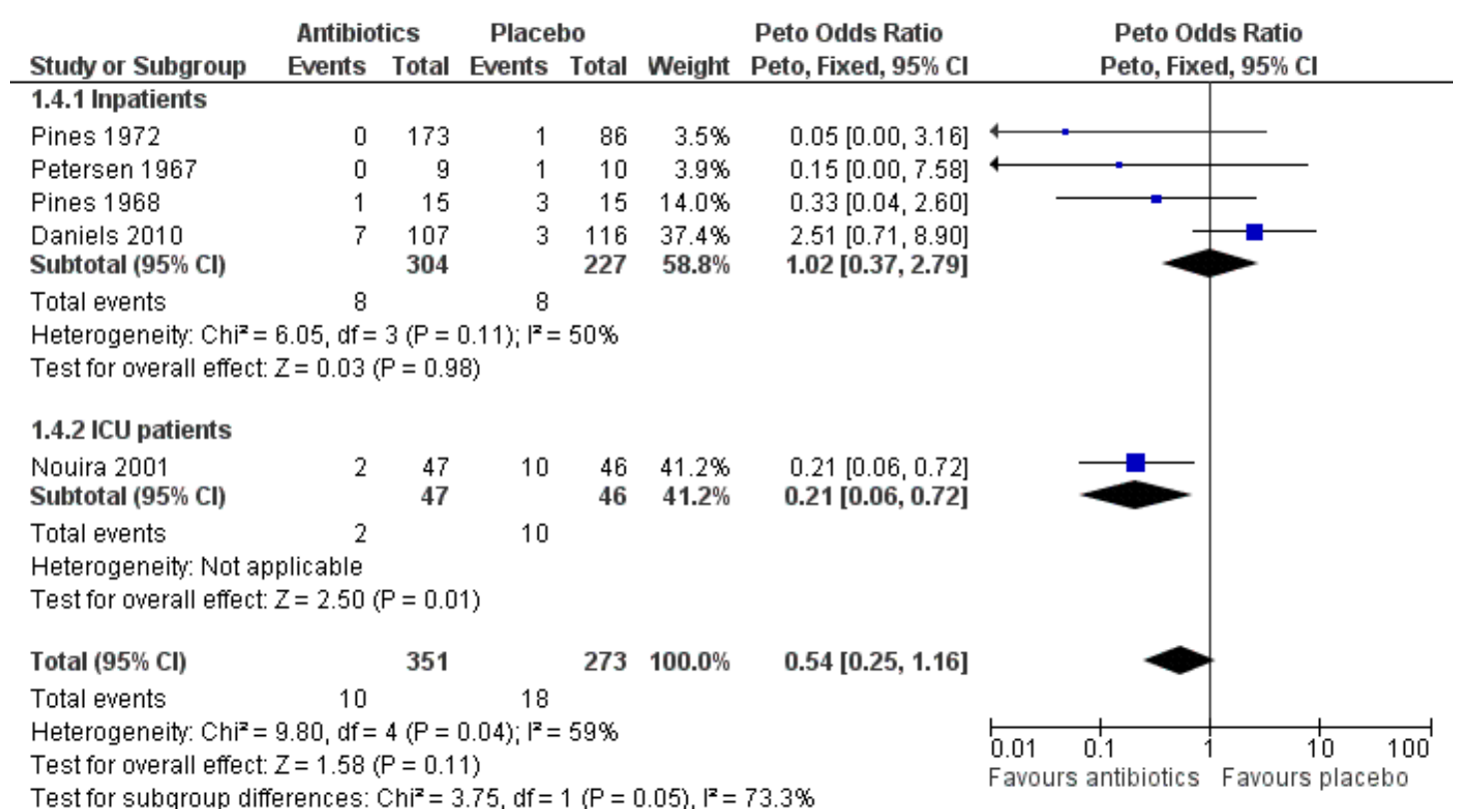

\section{Duration of hospital stay}

Three trials with 202 patients reported length of hospital stay (measured in days). Of these three trials two favoured neither antibiotics nor placebo (Alonso Martinez 1992; Manresa 1987). The third trial (Nouira 2001), an ICU trial, clearly favoured antibiotics (MD -9.60; 95\% CI -12.84 to -6.36).

\section{Dyspnoea}

Two studies with 300 patients reported dyspnoea at the end of the study period (ABC 2009; Daniels 2010). There was no significant improvement in dyspnoea in either trial (outpatients: MD 0.00;
95\% CI -0.97 to 0.97 ; inpatients: MD $-0.60 ; 95 \% \mathrm{CI}-1.27$ to 0.07) (Analysis 1.6).

\section{Outcomes with only one included trial}

\section{Health-related quality of life}

One outpatient trial (ABC 2009) with 35 patients reported healthrelated quality of life and showed no statistically significant difference between the treatment and control group (MD 0.00; 95\% CI -1.79 to 1.79 ) (Analysis 1.7 ). 


\section{Re-exacerbations}

One trial (ABC 2009) with 35 patients reported number of patients with re-exacerbations within two to six weeks. In the antibiotics group, there were two re-exacerbations compared to one in the placebo group (RR 1.89; 95\% CI 0.19 to 18.97) (Analysis $1.8)$.

\section{Days off work}

Elmes 1957, the oldest trial, reported days off work. The antibiotics group had statistically significantly fewer days off work compared with the placebo group (MD -5.18; 95\% CI -6.08 to -4.28) (Analysis 1.9).

\section{Grading}

The 'Summary of findings' table shows that the quality of evidence was low for the effect estimates of antibiotics on treatment failure in outpatients because of the discrepancy between the statistical significance of meta-analysis that includes all trials versus the meta-analysis that is restricted to currently used drugs (amoxicillin-clavulanic acid, trimethoprim/sulphamethoxazole, doxycycline, penicillin) and because the results from one trial were not made available by the study authors. For inpatients and patients admitted to the ICU we considered the results for the outcome treatment failure to be high. Since there was substantial heterogeneity across trials in inpatients that assessed the effects of antibiotics on mortality and because the results were imprecise we downgraded the quality of evidence to low. The quality of evidence on the effects of antibiotics on mortality in patients admitted to the ICU was high. For adverse events, we considered the quality of evidence to be high for the outcome of diarrhoea but downgraded the quality of evidence for any adverse events because of imprecision. It is uncertain if the lower limit of the $95 \%$ CI would be below 1.0 with additional trials.

\section{DISCUSSION}

\section{Summary of main results}

The meta-analyses showed that antibiotics for acute exacerbations of COPD reduced treatment failure statistically significantly for outpatients when all trials from 1957 to 2012 were included but not when the analyses were restricted to currently used antibiotics. Antibiotics had a statistically significant effect on treatment failure in inpatients and patients treated in the ICU. There was a statistically significant reduction in the risk of mortality among ICU patients with the use of antibiotics but not for inpatients (no data for outpatients available). There was a statistically significant increase in the risk of adverse events with antibiotic use compared to placebo. Length of hospital stay was not significantly reduced by antibiotics except for ICU patients. There were few data on the effects of antibiotics on health-related quality of life or other patient-reported symptoms.

\section{Overall completeness and applicability of evidence}

The severity of underlying COPD could not be studied as a potential source of heterogeneity. Trials with information on COPD severity are rare as lung function tests are difficult to perform during exacerbations and as lung function results are rarely available from the pre-exacerbation period. Also, the definitions and classifications of COPD have changed over the years so that no uniform classifications of COPD could be extracted from the studies. Nevertheless, the results from this review appear to be applicable to patients with moderate to severe COPD who typically suffer from exacerbations.

There was no common definition for severity of exacerbation that was used in the trials. There is uncertainty on the thresholds of admitting patients to hospital and whether this was comparable among trials. Thus stratification according to setting is just a proxy for the severity of exacerbation although such an event-based definition is commonly used in COPD research (Rodriguez-Roisin 2000). Our finding that the effects of antibiotics depend on the severity of exacerbations is supported by the Anthonisen 1987 trial, which showed a benefit for the most severe exacerbations but not for mild exacerbations. In contrast, the results of the metaanalyses for treatment failure in outpatients and inpatients (nonICU patients) showed almost identical results. This may suggest that our conservative approach of keeping outpatients and inpatients separate was not necessary and that there are other determinants of hospital admission than the severity of an exacerbation only.

Only two small trials reported patient-important outcomes such as health-related quality of life or days off work, which is heavily influenced by exacerbations and one of the main targets of COPD treatments.

With a relatively high NNTH it could be argued that treating outpatients with antibiotics is not problematic as some may still benefit. This disregards the consistent and growing problem of resistance against antibiotics and the need to decrease the overutilisation of unnecessary antibiotics (WHO factsheet no. 194). Overall, there is a strong beneficial effect of antibiotics in ICU patients. In inpatients and outpatients there is some effect of antibiotics but the effects are small and inconsistent for some outcomes (treatment failure) and absent for other outcomes (mortality, length of hospital stay).

\section{Quality of the evidence}


We restricted our systematic review to RCTs and found 16 placebocontrolled RCTs with 2068 patients. Starting with the assumption that RCTs provide high-quality evidence, we did not downgrade the quality of evidence for risk of bias for any outcome because the risk of bias was low for most trials. We downgraded the analyses for some outcomes for inconsistency, which is not unexpected given the heterogeneity of patients with COPD. As a consequence of the small number of patients and events, we downgraded the quality of evidence for mortality in inpatients. We expect, based on our assessment of the quality of evidence, that additional trials could change the results for treatment failure in outpatients and for mortality in inpatients.

\section{Potential biases in the review process}

Although treatment failure is commonly used in meta-analyses, it is a limitation that definitions of treatment failure differ across trials. It is difficult to standardise the definition of treatment failure because it may include patient-reported symptoms, clinical signs and results from laboratory tests or imaging. However, we do not have reason to believe that different definitions of treatment failure caused heterogeneity in our meta-analyses. Also, we could not assess the influence of other factors such as season, co-morbidities or concurrent medication use such as systemic corticosteroids or bronchodilators as they were reported inconsistently and to a limited extent.

A limitation of the present systematic review is publication bias, which is a potential threat to any systematic review. Studies demonstrating a positive effect for antibiotics may be more likely to be published than negative studies. In order to minimise missing studies we used extensive trial search criteria with no language restrictions and made every effort to detect any unpublished or ongoing studies and contacted authors of the included trials, some of whom provided additional information about their data. However, we have reasons to believe that the results of two trials are not yet in the public domain and we, therefore, downgraded the quality of evidence for the outcome of treatment failure in outpatients.

\section{Agreements and disagreements with other studies or reviews}

Our systematic review is in agreement with a former review (Puhan 2007), and the findings did not change substantially with the addition of three new trials (ABC 2009; Daniels 2010; Llor 2012). We agree with the former Cochrane review on this topic (Ram 2006) on treatment failure in inpatients but we disagree with several other outcomes and the review's conclusions. The former Cochrane review used several different outcomes such as peak flow, lung function, sputum purulence and blood gases, which we believe are not the important, patient-relevant outcomes to estimate the value of antibiotics for the management of acute COPD exac- erbations. Also, the former review included a study that was not an RCT (Elmes 1965) and excluded a study that actually was an RCT (Berry 1960). In addition, we were able to obtain COPDspecific data from one RCT (Sachs 1995) that reported on the results for both asthma and COPD patients. Also, our results for mortality in inpatients differ from those of the former Cochrane review because that review included the Elmes trials (Elmes 1965) and did not keep ICU and inpatients separate.

The systematic review of Saint 1995 combined results from different outcomes in a meta-analysis. Nevertheless, the authors concluded an overall combined standardised mean effect size estimate of 0.22 (95\% CI 0.1 to 0.34$)$ indicating a small but statistically significant effect favouring antibiotics over placebo. We think that combining different outcomes and using standardised effect sizes is an inappropriate way to pool results.

\section{AUTHORS, CONCLUSIONS}

\section{Implications for practice}

There is continued uncertainty as to whether antibiotics provide a benefit to COPD patients with acute exacerbations that can be treated on an outpatient basis. Current data suggest that antibiotics do not significantly reduce treatment failure or improve the patients' health-related quality of life with currently available antibiotics. In patients who need hospital admission for severe exacerbations, antibiotics do reduce treatment failures but not the length of hospital stay or mortality. Finally, antibiotics reduce mortality, treatment failures and length of hospital stay in patients who need ICU care. The results of this systematic review provide evidence for developers of guidelines to consider the evidence base but also additional factors such as patient preferences, resistance of bacteria to antibiotics and cost to make practice recommendations.

\section{Implications for research}

In the large majority of COPD patients who are treated on an outpatient basis because of mild to moderate exacerbations additional placebo-controlled trials could determine the effectiveness of antibiotics on short- and long-term outcomes and on patientimportant outcomes such as health-related quality of life. It is challenging to recruit outpatients for placebo-controlled trials because of widespread beliefs about the positive effects of antibiotics. But as our review suggests, withholding antibiotics in outpatients and even in inpatients did not or only slightly increase the risk for treatment failure and mortality so that placebo-controlled RCTs are still justifiable.

The conflicting evidence raised discussions about (bio-) markers, which could predict a bacterial infection and help to select patients who benefit from antibiotic treatment and save antibiotics in those who are unlikely to benefit. Sputum purulence is one of the most 
discussed indicators that could be used to guide antibiotic therapy. It is noteworthy that there are no adequately powered RCTs that assessed effect modification by the presence or absence of purulent sputum. Indirect evidence on effect modification is available from the trials included in this systematic review. Four trials (ABC 2009; Elmes 1957; Pines 1968; Pines 1972) included patients with purulent sputum only or positive gram stain, although few details on how purulent sputum was defined and measured were available. Of these four trials only one showed a statistically significant effect on treatment failure (Pines 1968) and the only most recent trial (ABC 2009) did showed no effects on any of the outcomes. Also, there is no indication from the trials included in this review that these trials show results that are different from those trials that did not restrict the study population to patients with purulent sputum. Biomarkers may also be promising to guide antibiotic treatment for COPD exacerbations. C-reactive protein (CRP) or $\mathrm{B}$-type natriuretic peptide may be promising because they are relatively cheap and easily available in inpatient and outpatient settings (Llor 2012; Daniels 2010b). There are additional candidates for guiding antibiotic treatment, such as procalcitonin, but their cost currently limits their use to highly specialised settings.

There are different types of studies that could be done to determine the potential of clinical signs and biomarkers to guide antibiotic therapy for COPD exacerbations. Additional placebo-controlled trials could assess whether the effects of antibiotics (versus placebo) are different in patients with (or without) purulent sputum or with different levels of a biomarker. Such trials would require relatively large sample sizes in order to assess subgroup effects (effect modification) formally. Alternatively, more pragmatic trials could be done where physicians are randomised to using or not using a clinical sign or biomarker to guide the prescription of antibiotics. Such trials would typically be non-inferiority trials that aim to show that the clinical benefit is not worse when using a clinical sign or biomarker but that adverse effects, cost and bacterial resistance could be limited by less use of antibiotics. One Cochrane review showed that procalcitonin guidance was not associated with increased mortality or treatment failure in patients with acute respiratory infections but significantly reduced overall antibiotics use (Schuetz 2012). Finally, observational studies may be used to look into the potential of clinical signs or biomarkers to predict outcomes of patients with COPD exacerbations. Such studies could either assess the independent predictive properties of clinical signs or biomarkers, or compare the outcomes with antibiotic treatment versus no antibiotic treatment in patients with or without a clinical sign or certain biomarker levels while adequately adjusting for selection mechanisms and confounding. Such observational studies appear more feasible than additional placebocontrolled RCTs but they may often be only hypothesis generating rather than providing high-quality evidence as a basis for treatment recommendations.

Finally, it would also be important to have more high-quality evidence on the long-term effects (re-exacerbations, health-related quality of life and mortality) of antibiotics in COPD patients with mild to moderate exacerbations. Also, head-to-head antibiotic trials continue to be important in COPD patients treated for exacerbations in inpatient and ICU settings because the susceptibility of strains is dynamic and may differ over time and from setting to setting.

\section{ACKNOWLEDGEMENTS}

We are grateful for support from staff of the Cochrane Airways Group, namely Emma Welsh (Managing Editor) and Elizabeth Stovold (Trials Search Co-ordinator). We would also like to thank JL Alonso Martinez, AF Jørgensen, AP Sachs and Dr F Blasi for responding to our requests for further information about their studies.

\section{REF E R E N C E S}

\section{References to studies included in this review}

\section{ABC 2009 \{published and unpublished data\}}

Brusse-Keizer M, van der Valk P, Hendrix R, Kerstjens H, van der Pale J. Necessity of antibiotics in outpatients with ACOPD exacerbation: the ABC-trial. PhD thesis 2009. [ISBN 978-90-365-2792-7; doc.utwente.nl/61073/ thesis' $M$ ' Brusse' Keizer.pdf]

* Brusse-Keizer MG, van der Valk PD, Hendrix MG, Kerstjens HA, van der Palen J. Antibiotics in patients with a mild to moderate home-treated COPD exacerbation: the $\mathrm{ABC}$ trial. American Journal of Respiratory and Critical Care Medicine 2009;179:A1493.
Allegra 1991 \{published data only (unpublished sought but not used)\}

* Allegra LGC, Grossi E, Pozzi E, Blasi F, Frigerio D, Nastri

A, et al. The role of antibiotics in the treatment of chronic bronchitis exacerbation: follow-up of a multicenter study. Italian Journal of Chest Disease 1991;45(3):138-48.

Alonso Martinez 1992 \{published data only\} Alonso Martinez JL, Rubio Obanos MT, Samperiz Legarre AL, Escolar Castellon F, Carrasco del Amo ME. Antibiotic treatment for acute episodes of chronic obstructive pulmonary disease [Tratamiento con antibioticos de las agudizaciones de la enfermedad pulmonar obstructiva cronica]. Anales de Medicina Interna 1992;9(8):377-80.

Anthonisen 1987 \{published data only\} Anthonisen NR, Manfreda J, Warren CP, Hershfield 
ES, Harding GK, Nelson NA. Antibiotic therapy in exacerbations of chronic obstructive pulmonary disease. Annals of Internal Medicine 1987;106(2):196-204.

Berry 1960 \{published data only\}

Berry DG, Fry J, Hindley CP. Exacerbations of chronic bronchitis treatment with oxytetracycline. Lancet 1960;1: 137-9. [PMID: 13799872]

Daniels 2010 \{published data only\}

Daniels JM, Schoorl M, Snijders D, Knol DL, Lutter R, Jansen HM, et al. Procalcitonin vs C-reactive protein as predictive markers of response to antibiotic therapy in acute exacerbations of COPD. Chest 2010;138(5):1108-15. Daniels JM, Snijders D, de Graaff CS, Vlaspolder F, Jansen HM, Boersma WG. Antibiotics in addition to systemic corticosteroids for acute exacerbations of chronic obstructive pulmonary disease. American Journal of Respiratory \& Critical Care Medicine 2010;181(2):150-7.

Elmes 1957 \{published data only\}

Elmes PC, Fletcher CM, Dutton AA. Prophylactic use of oxytetracycline for exacerbations of chronic bronchitis. British Medical Journal 1957;2:1272-5.

Fear 1962 \{published data only\}

Fear EC, Edwards G. Antibiotic regimes in chronic bronchitis. British Journal of Diseases of the Chest 1962;56: $153-62$.

Jørgensen 1992 \{published and unpublished data\} Jørgensen AF, Coolidge J, Pedersen PA, Petersen KP, Waldorff S, Widding E. Amoxicillin in treatment of acute uncomplicated exacerbations of chronic bronchitis. A double-blind, placebo-controlled multicentre study in general practice. Scandinavian Journal of Primary Health Care 1992;10(1):7-11.

\section{Llor 2012 \{published data only\}}

Llor C, Moragas A, Hernandez S, Bayona C, Miravitlles M. Efficacy of antibiotic therapy for acute exacerbations of mild to moderate COPD. American Journal of Respiratory and Critical Care Medicine 2012; Vol. 186, issue 8:716-23.

Manresa 1987 \{published data only\}

Manresa F, Blavia R, Martin R, Linares J, Rodriguez B, Verdaguer R. Antibiotics for exacerbations of chronic bronchitis. Lancet 1987; Vol. 2, issue 8555:394-5. [PMID: 2886848]

Nouira 2001 \{published data only\}

Nouira S, Marghli S, Belghith M, Besbes L, Elatrous S, Abroug F. Once daily oral ofloxacin in chronic obstructive pulmonary disease exacerbation requiring mechanical ventilation: a randomised placebo-controlled trial. Lancet 2001;358(9298):2020-5.

Petersen 1967 \{published data only\}

Petersen ES, Esmann V, Honcke P, Munkner C. A controlled study of the effect of treatment on chronic bronchitis. An evaluation using pulmonary function tests. Acta Medica Scandinavica 1967;182(3):293-305.

Pines 1968 \{published data only\}

Pines A, Raafat H, Plucinski K, Greenfield JS, Solari M. Antibiotic regimens in severe and acute purulent exacerbations of chronic bronchitis. British Medical Journal 1968;2(607):735-8.

Pines 1972 \{published data only\}

Pines A, Raafat H, Greenfield JS, Linsell WD, Solari ME. Antibiotic regimens in moderately ill patients with purulent exacerbations of chronic bronchitis. British Journal of Diseases of the Chest 1972;66(2):107-15. [PMID: 4556292]

Sachs 1995 \{published and unpublished data\}

Sachs AP, Koëter GH, Groenier KH, van der Waaij D, Schiphuis J, Meyboom-de Jong B. Changes in symptoms, peak expiratory flow, and sputum flora during treatment with antibiotics of exacerbations in patients with chronic obstructive pulmonary disease in general practice. Thorax 1995;50(7):758-63.

\section{References to studies excluded from this review}

Aitchison 1968 \{published data only\}

Aitchison WR, Grant IW, Gould JC. Treatment of acute exacerbations in chronic bronchitis. British Journal of Clinical Practice 1968;22(8):343-5.

Alix 1979 \{published data only\}

Alix M, Ardenna A, Brion G, Marquinio V, Mejia H, Oh F. Randomized, open, comparative multi-center trial evaluating the effectiveness and toleration of doxycycline, ampicillin and cotrimoxazole in the treatment of lower respiratory infections (a collaborative study). Philippine Journal of Microbiology and Infectious Diseases 1979;8(2): 123-31.

Allan 1966 \{published data only\} Allan GW, Fallon RJ, Lees AW, Smith J, Tyrrell WF. A comparison between ampicillin and tetracycline in purulent chronic bronchitis. British Journal of Diseases of the Chest 1966;60(1):40-3.

Allegra 1996 \{published data only\} Allegra L, Konietzko N, Leophonte P, Hosie J, Pauwels $\mathrm{R}$, Guyen JN, et al. Comparative safety and efficacy of sparfloxacin in the treatment of acute exacerbations of chronic obstructive pulmonary disease: a doubleblind, randomised, parallel, multicentre study. Journal of Antimicrobial Chemotherapy 1996;37(Suppl A):93-104. [PMID: 8737129]

Alvarez-Sala 2006 \{published data only\} Alvarez-Sala JL, Kardos P, Martinez-Beltran J, Coronel P, Aguilar L, Ceditoren AECB Working Group. Clinical and bacteriological efficacy in treatment of acute exacerbations of chronic bronchitis with cefditorenpivoxil versus cefuroxime-axetil. Antimicrobial Agents and Chemotherapy 2006;50(5):1762-67. [DOI: 10.1128/ AAC. 50.5.1762\%E2\%80\%931767.2006]

Andrijevic 2011 \{published data only\} Andrijevic I, Povazan D, Andrijevic L, Povazan A, Milutinov S. Treatment effects of co-amoxiclav (Amoxiclav 2x) in acute exacerbation of severe chronic obstructive pulmonary disease: clinical evaluation

[Ле че ње е фект и с ар а ње 
амокицлав (амокицлав 2к) у

акутној погоршања тешке

хроничне опструктивне

болестиплућа:клиничка

е в а л у а ц и ј а ]. Medicinski Pregled 2011;64(34):178-82.

Anon 1969 \{published data only\}

Anonymous. Trimethoprim-sulphamethoxazole in chronic bronchitis. The Practitioner 1969;203(218):817-9.

Anon 1972 \{published data only\}

Anonymous. A further comparative trial of co-trimoxazole in chronic bronchitis. The Practitioner 1972;209(254): 838-40.

Banerjee 2001 \{published data only\}

Banerjee D, Hussain S, Khair O, Honeybourne D. The effects of oral clarithromycin on airway inflammation in moderate to severe chronic obstructive pulmonary disease (COPD) - a double blind randomised controlled trial. European Respiratory Journal 2001;18(Suppl 33):338s.

Bekçi 2009 \{published data only\} Bekçi T, Kurtipek E, Kesli R, Maden E, Teke T. The effect of telithromycin on inflammatory markers in chronic obstructive pulmonary diseases. European Journal of General Medicine 2009;6(4):218-22.

Bennion-Pedley 1969 \{published data only\} Bennion-Pedley J. Treatment of acute exacerbations of chronic bronchitis in general practice. British Journal of Clinical Practice 1969;23(7):280-3.

Braendli 1982 \{published data only\} Braendli O, Keller R, Fruehauf B. Brodimoprim(®) (RO 10-5970) versus doxycyclin in chronic bronchitis. A randomized controlled clinical trial. Chemioterapia 1982;1 (4 Suppl): 157 .

Burgi 1975 \{published data only\}

Burgi H. Method of evaluation of the efficiency of an antibiotic in chronic bronchitis. Application to the study of amoxicillin [Procédé d'évaluation de l'efficacité d'un antibiotique dans la bronchite chronique. Application à l'étude de l'amoxicilline]. Nouvelle Presse Medicale 1975;4 (34):2453-6.

Burrow 1975 \{published data only\}

Burrow G, Fox A, Daniel R. A comparative trial of Minocin (Minocycline Hydrochloride) and ampicillin in the treatment of acute exacerbations of chronic bronchitis. Journal of International Medical Research 1975;3:304-8.

Chatterjee 2011 \{published data only\}

Chatterjee S, Biswas T, Dutta A, Sengupta G, Mitra A, Kundu S. Clinical effectiveness and safety of gemifloxacin versus cefpodoxime in acute exacerbation of chronic bronchitis: a randomized, controlled trial. Indian Journal of Pharmacology 2011;43(1):40-4. [10.4103/ 0253-7613.75667]
Chen 2000 \{published data only\}

Chen DY, Tang XY, Chen WB. A randomized controlled study of levofloxacin and cefaclor in the treatment of lower respiratory tract infections of patients with chronic obstructive pulmonary diseases. Sichuan Medical Journal 2000;21(6):481-3.

Christiansen 1963 \{published data only\}

Christiansen I, Midtgaard K. A comparison of sulfonamide and penicillin treatment of acute exacerbations in chronic bronchitis [in Danish]. Ugeskrift for Laeger 1963;125(30): $1041-4$.

Citron 1969 \{published data only\}

Citron KM, May JR. Rifamycin antibiotics in chronic purulent bronchitis. Lancet 1969;2(7628):982-3.

Dong 2005 \{published data only\} Dong L, Wang SC, Sun EH, Yu QF, Zhang Q, Wu DW. Study on efficacy of moxifloxacin in the treatment of $\mathrm{AECB}$ and its antimicrobial activity in vitro. Chinese Pharmaceutical Journal 2005;40(9):702-4.

Douglas 1957 \{published data only\}

Douglas AC, Somner AR, Marks BL, Grant IWB. Effect of antibiotics on purulent sputum in chronic bronchitis and bronchiectasis. The Lancet 1957;273(6988):214-18. [PUBMED: 13450378 ]

Egede 1993 \{published data only\}

Egede F, Nielsen PB, Husfeldt P. Ofloxacin and erythromycin in acute exacerbations of chronic bronchitis. Drugs 1993;45 Suppl 3:410.

Elmes 1965 \{published data only\} Elmes PC, King TK, Langlands JH, Mackay JA, Wallace WF, Wade OL, et al. Value of ampicillin in the hospital treatment of exacerbations of chronic bronchitis. British Medical Journal 1965;5467:904-8.

Fartoukh 2004 \{published data only\}

Fartoukh M, Similowski T, Brun-Buisson C. ANTEAB: a study of early antibiotic therapy in intensive care management of acute exacerbations of chronic obstructive lung disease. Revue des Maladies Respiratoires 2004;21(2 Pt 1):381-9. [PMID: 15211249]

Filipovic 2000 \{published data only\}

Filipovic M, Pljaskic Kamenov S, Siric Z, Kamenov B, Cekic $S$. Erythromycin in the treatment of acute exacerbations of chronic obstructive pulmonary disease (COPD). Respiratory Medicine 2000;94 Suppl A:A.

Francis 1960 \{published data only\}

Francis RS, Spicer CC. Chemotherapy in chronic bronchitis. British Medical Journal 1960;1(5169):297-303. [PUBMED: PMC1966487]

Francis 1964 \{published data only\} Francis RS, May JR, Spicer CC. Influence of daily penicillin, tetracycline, erythromycin, and sulphamethoxypyridazine on exacerbations of bronchitis. A report to the Research Committee of the British Tuberculosis Association. British Medical Journal 1964;1(5385):728-32. 
Fruensgaard 1972 \{published data only\}

Fruensgaard K, Korner B. [Trimethoprim-sulfamethoxazole compared with ampicillin in exacerbations of chronic bronchitis]. [Danish]. Ugeskrift for Laeger 1972;134(26): 1377-81.

Gaillat 2007 \{published data only\}

Gaillat J, Garau J, Sethi S, Anzueto A, Guillemot D, Weber P. Impact of telithromycin (T), azithromycin (A) and cefuroxime axetil (C) on the carriage of resistant $S$ treptococcus pneumoniae $(S p)$ in pts with acute exacerbation of chronic bronchitis (AECB). European Respiratory Journal 2007; Vol. 30, issue Suppl 51:227s.

Gocke 1964 \{published data only\} Gocke TM, Laurenzi GA. Ampicillin therapy of acute exacerbations of chronic obstructive lung disease. Antimicrobial Agents and Chemotherapy (Bethesda) 1964;10: 686-91.

Goddard 2003 \{published data only\} Goddard RD, McNeil SA, Slayter KL, McIvor RA. Antimicrobials in acute exacerbations of chronic obstructive pulmonary disease - an analysis of the time to next exacerbation before and after the implementation of standing orders. Canadian Journal of Infectious Diseases \& Medical Microbiology 2003;14(5):254-9.

Gomez 2000 \{published data only\}

Gomez J, Banos V, Simarro E, Lorenzo Cruz M, Ruiz Gomez J, Latour J, et al. Prospective, comparative study (1994-1998) of the influence of short-term prophylactic treatment with azithromycin on patients with advanced COPD [Estudio prospectivo, comparativo (1994-1998) de la influencia de corto plazo, el tratamiento profiláctico con azitromicina en pacientes con EPOC avanzada]. Revista Española de Quimioterapia 2000;13(4):379-83. [PMID: 11498704]

Gotfried 2007 \{published data only\}

Gotfried M, Busman TA, Norris S, Notario GF. Role for 5-day, once-daily extended-release clarithromycin in acute bacterial exacerbation of chronic bronchitis. Current Medical Research and Opinion 2007;23(2):459-66. [DOI: 10.1185/030079906X162827]

Guerin 1987 \{published data only\}

Guerin JC, Lebeau B, Leophonte P, Taytard A, Muir JF. Double blind comparative study of doxycyclin versus amoxicillin in infectious exacerbations of chronic bronchitis. Medecine et Maladies Infectieuses 1987;17(12):756-61.

Haanaes 1980 \{published data only\}

Haanaes OC, Grimne G. Pivampicillin in exacerbations of chronic bronchitis [in Norwegian]. Tidsskrift for Den Norske Laegeforening 1980;100(32):1900-2.

Hansen 1986 \{published data only\}

Hansen M. Antibiotics in the treatment of exacerbations in patients with chronic bronchitis [in Danish]. Ugeskrift for Laeger 1986;148(4):191-3.

Hansen 1990 \{published data only\} Hansen M, Evald T, Balslov S. A randomized double-blind trial between amoxycillin and placebo in the treatment of acute exacerbations of chronic bronchitis. European

Respiratory Journal 1990;3(Suppl 10):89.

Hauke 2002 \{published data only\}

Hauke W, Kohler G, Henneicke-Von Zepelin HH, Freudenstein J. Esberitox $\mathrm{N}$ as supportive therapy when providing standard antibiotic treatment in subjects with a severe bacterial infection (acute exacerbation of chronic bronchitis). A multicentric, prospective, double-blind, placebo-controlled study. Chemotherapy 2002;48(5): 259-66. [PMID: 12476043]

Hopkins 1962 \{published data only\} Hopkins EJ, Pye AM, Solomon M, Solomon S. The treatment of exacerbations of chronic bronchitis in general practice. A comparison between oxytetracycline and oral phenoxymethyl penicillin. Journal of the College of General Practitioners 1962;5:59-65.

Jacobsen 2002 \{published data only\} Jacobsen SK, Weis N, Almdal T. Use of antibiotics in patients admitted to the hospital due to acute exacerbation of chronic obstructive pulmonary disease (COPD). European Journal of Internal Medicine 2002;13:514-7.

Jia 2010 \{published data only\}

Jia B, Lu P, Huang W, Li C, Huang A, Zhou X, et al. A multicenter, randomized controlled clinical study on biapenem and imipenem/cilastatin injection in the treatment of respiratory and urinary tract infections. Chemotherapy 2010;56:285-90. [DOI: 10.1159/ 000319952]

Johnston 1961 \{published data only\} Johnston RN, Lockhart W, Smith DH. A trial of phenethicillin in chronic bronchitis. British Medical Journal 1961;2(5258):985-6. [PUBMED: PMC1970174]

Kaul 1967 \{published data only\} Kaul S, Verma SL, Razdan MK, Kaul SN, Razdan PN. Management of acute exacerbations in chronic bronchitis. A clinical trial. Indian Journal of Medical Sciences 1967;21 (1):16-21.

King 1996 \{published data only\} King DE, Williams WC, Bishop L, Shechter A. Effectiveness of erythromycin in the treatment of acute bronchitis. Journal of Family Practice 1996;42(6):601-5.

Leophonte 1998 \{published data only\} Leophonte P, Murris-Espin M, Berthier A, Dayan M. The place of antimicrobial chemotherapy in the treatment of adults with acute bronchitis: a double-blind placebocontrolled trial. Clinical Microbiology and Infection 1998;4 (8):436-41.

Lirsac 2000 \{published data only\}

Lirsac B, Benezet O, Dansin E, Nouvet G, Stach B, Voisin C. Evaluation and symptomatic treatment of superinfectious exacerbations of COPD: preliminary study of antibiotic treatment combined with fenspiride (Pneumorel $80 \mathrm{mg}$ ) versus placebo [L'évaluation et le traitement symptomatique des exacerbations de la MPOC surinfectious: étude préliminaire du traitement antibiotique associé à fenspiride 
(Pneumorel $80 \mathrm{mg}$ ) versus placebo]. Revue de Pneumologie Clinique 2000;56(1):17-24. [PMID: 10740110]

\section{Maesen 1976 \{published data only\}}

Maesen FP, Beeuwkes H, Davies BI, Buytendijk HJ, Brombacher PJ, Wessman J. Bacampicillin in acute exacerbations of chronic bronchitis - a dose-range study. Journal of Antimicrobial Chemotherapy 1976;2(3):279-85.

Maesen 1980 \{published data only\} Maesen FP, Davies BI, Drenth BM, Elfers H. Treatment of acute exacerbations of chronic bronchitis with cefotaxime: a controlled clinical trial. Journal of Antimicrobial Chemotherapy 1980;6 Suppl A:187-92.

Malone 1968 \{published data only\} Malone DN, Gold JC, Grant IW. A comparative study of ampicillin, tetracycline hydrochloride, and methacycline hydrochloride in acute exacerbations of chronic bronchitis. Lancet 1968;2(7568):594-6.

May 1964 \{published data only\} May JR, Hurford JV, Little GM, Delves DM. Chemotherapy of Chronic Bronchitis with Large Doses of Ampicillin. The Lancet 1964;284(7357):444-5. [DOI: $10.1016 /$ S0140-6736(64)90333-2]

Miravitlles 2009 \{published data only\} Miravitlles M, Marin A, Monso E, Vila S, de la Roza C, Hervas R, et al. Efficacy of moxifloxacin in the treatment of bronchial colonisation in COPD. European Respiratory Journal 2009;34:1066-71. [DOI: 10.1183/ 09031936.00195608]

\section{NCT00255983 \{published data only\}} NCT00255983. Double blind trial to evaluate the efficacy and safety of faropenem medoxomil in the treatment of chronic bronchitis. clinicaltrials.gov/show/NCT00255983 (accessed 23 October 2012).

Nicotra 1982 \{published data only\}

Nicotra MB, Rivera M, Awe RJ. Antibiotic therapy of acute exacerbations of chronic bronchitis. A controlled study using tetracycline. Annals of Internal Medicine 1982;97(1): $18-21$.

Nonikov 2001 \{published data only\}

Nonikov VE, Il'kovich MM, Konstantinova TD, Korovina OV, Lenkova NI, Ovcharenko SI, et al. Spiramycin and roxytromycin for the treatment of pneumonia

and chronic bronchitis exacerbation $[\mathrm{O} ц$ е н к а

исимптоматическое

леч чени е surinfectious о бост рений

ХОБЛ:предварительное

исследование лечения

ант и и иотиками в

сочетаниис фенспирида

( Pneumorel $80 \mathrm{M} \mathrm{г} \mathrm{)} \mathrm{п} \mathrm{о} \mathrm{с} \mathrm{р} \mathrm{а} \mathrm{в} \mathrm{нен} \mathrm{и} \mathrm{ю} \mathrm{с}$ п л а ц е б о ]. Antibiotiki i Khimioterapiia 2001;46 (3):26-8.

Parnham 2005 \{published data only\} Parnham MJ, Culic O, Erakovic V, Munic V, PopovicGrle S, Barisic K, et al. Modulation of neutrophil and inflammation markers in chronic obstructive pulmonary disease by short-term azithromycin treatment. European Journal of Pharmacology 2005;517:132-43. [DOI: 10.1016/j.ejphar.2005.05.023]

Peng 2003 \{published data only\} Peng CC, Aspinall SL, Good CB, Atwood CW Jr, Chang CC. Equal effectiveness of older traditional antibiotics and newer broad-spectrum antibiotics in treating patients with acute exacerbations of chronic bronchitis. Southern Medical Journal 2003;96(10):986-91. [PMID: 14570342]

\section{Pham 1964 \{published data only\}}

Pham QT, Sadoul P. Treatment of acute bronchitis patients with an attack of acute superinfection with an association of antibiotics (colistin and penicillin) [in French]. Semaine thérapeutiqueo 1964;40(5):335-8.

\section{Pines 1967 \{published data only\}}

Pines A, Raafat H. Controlled comparisons of cephaloridine with penicillin and streptomycin in chronic purulent bronchitis. Postgraduate Medical Journal 1967;43(Suppl 43):61-3.

\section{Pines 1969 \{published data only\}}

Pines A, Raafat H, Plucinski K, Greenfield JS, Solari M. A comparison of erythromycin, novobiocin, tetracycline and a novobiocin-tetracycline combination in purulent exacerbations of chronic bronchitis. British Journal of Diseases of the Chest 1969;63(4):206-14.

Pines 1972a \{published data only\}

Pines A, Khaja G, Greenfield JS, Raafat H, Sreedharan KS, Linsell WD. A double-blind comparison of slow-release tetracycline and tetracycline hydrochloride in purulent exacerbations of chronic bronchitis. British Journal of Clinical Practice 1972;26(10):475-6.

Pines 1973 \{published data only\}

Pines A. Trimethoprim-sulfamethoxazole in the treatment and prevention of purulent exacerbations of chronic bronchitis. Journal of Infectious Diseases 1973;128:Suppl 9.

Pines 1973a \{published data only\}

Pines A, Greenfield JS, Raafat H, Sreedharan KS. A comparison of pivampicillin and ampicillin in exacerbations of chronic bronchitis. British Journal of Diseases of the Chest 1973;67(3):221-6.

Pines 1974 \{published data only\}

Pines A, Raafat H, Sreedharan KS, Parker P. A comparison of pivampicillin and tetracycline in exacerbations of chronic bronchitis. Chemotherapy 1974;20(6):361-9.

\section{PRITZL 1959 \{published data only\}}

* Pritzl FP, Duda G. On the efficacy of butazolidine in the treatment of chronic bronchitis [Von der Wirksamkeit der butazolidine bei der Behandlung von chronischer Bronchitis]. Medizinische 1959;51:2538-40. 
Puchelle 1975 \{published data only\}

Puchelle E, Sobradillo V, Aug F, Sadoul P. Amoxicillin and ampicillin in the patient with chronic bronchitis. Comparative study: bacteriological, pharmacological and clinical [Amoxicilline et ampicilline chez le bronchiteux chronique. Etude comparée: bactériologique, pharmacologique et clinique]. La Nouvelle Presse Médicale 1975;4(34):2449-52.

Pugh 1964 \{published data only\}

Pugh DL. Propicillin in the treatment of chronic bronchitis. British Journal of Clinical Practice 1964;18(2):81-8. [PUBMED: 14115579]

Rethly 1961 \{published data only\} Rethly E, Brenner F. Treatment of chronic purulent bronchitis with antibiotics [in German]. Zeitschrift für die gesamte innere Medizin und ihre Grenzgebiete 1961;16: 1034-7.

Roede 2007 \{published data only\} Roede BM, Bresser P, El Moussaoui R, Krouwels FH, van den Berg BTJ, Hooghiemstra PM, et al. Three vs. 10 days of amoxycillin-clavulanic acid for type 1 acute exacerbations of chronic obstructive pulmonary disease: a randomised, double-blind study. Clinical Microbiology and Infection 2007;13(3):284-90. [PUBMED: 17391383]

Romanovskikh 2007 \{published data only\} Romanovskikh A, Sinopalinkov A, Ratchina S. Open label randomized, comparative trial of the efficacy of levofloxacin versus clarithromycin SR. European Respiratory Journal 2007;30(Supp 51):674s E3919.

Ross 1973 \{published data only\}

Ross G I, Croydon EA. A winter-long trial of ampicillin in chronic bronchitis. British Journal of Diseases of the Chest 1973;67(2):153-60.

Sethi 2007 \{published data only\}

Sethi S, Kruesmann F, Haverstock D, Peroncel R, Choudri $S$. Correlation between eradication of infecting organism on days 3-5 of antibiotic therapy and clinical care in patients with acute exacerbations of chronic bronchitis. European Respiratory Journal 2007;30(Supp 51):223s.

Sethi 2010 \{published data only\}

Sethi S, Jones PW, Schmitt Theron M, Miravitlles M, Rubinstein E, Wedzicha JA, et al. Pulsed moxifloxacin for the prevention of exacerbations of chronic obstructive pulmonary disease: a randomized controlled trial. Respiratory Research 2010;11:10. [DOI: 10.1186/ 1465-9921-11-10]

Smyllie 1972 \{published data only\} Smyllie HC, Lacey WB. A comparison of trimethoprim/ sulphamethoxazole compound and tetracycline in exacerbations of chronic bronchitis. British Journal of Diseases of the Chest 1972;66:199-206.

Sohy 2002 \{published data only\}

Sohy C, Pilette C, Niederman MS, Sibille Y. Acute exacerbation of chronic obstructive pulmonary disease and antibiotics: what studies are still needed?. European Respiratory Journal 2002;19(5):966-75.

Soler 2003 \{published data only\}

Soler M, Lode H, Baldwin R, Levine JH, Schreurs AJ, van Noord JA, et al. Randomised double-blind comparison of oral gatifloxacin and co-amoxiclav for acute exacerbations of chronic bronchitis. European Journal of Clinical Microbiology and Infectious Diseases 2003;22:144-50.

Stolz 2007 \{published data only\}

Stolz D, Christ-Crain M, Bingisser R, Leuppi J, Miedinger $\mathrm{D}$, Muller $\mathrm{C}$, et al. Antibiotic treatment of exacerbations of COPD: a randomized, controlled trial comparing procalcitonin-guidance with standard therapy. Chest 2007; 131(1):9-19. [DOI: 10.1378/chest.06-1500]

Suzuki 2001 \{published data only\} Suzuki T, Yanai M, Yamaya M, Satoh-Nakagawa T, Sekizawa $\mathrm{K}$, Ishida $\mathrm{S}$, et al. Erythromycin and common cold in COPD. Chest 2001;120(3):730-3. [PMID: 11555501]

Tremolieres 2000 \{published data only\}

Tremolieres F. Augmentin $1 \mathrm{~g} / 125 \mathrm{mg} 2$ times a day in acute exacerbations of chronic bronchitis [in French]. Presse Medicale 2000;29(26 Suppl):11-3.

Williams 1981 \{published data only\}

Williams HN, John DW, Brown P, Rose AJ. A double blind comparison of talampicillin and ampicillin in the treatment of exacerbations of chronic bronchitis in general practice. British Journal of Clinical Practice 1981;35(4):147-52.

Wilson 2004 \{published data only\} Wilson R, Allegra L, Huchon G, Izquierdo J-L, Jones P, Schaberg T, et al. Short-term and long-term outcomes of moxifloxacin compared to standard antibiotic treatment in acute-exacerbations of chronic bronchitis. Chest 2004;125 (3):953-64.

Wilson 2011 \{published data only\}

* Wilson R, Anzueto A, Miravitlles M, Arvis P, Haverstock $\mathrm{D}$, Trajanovic M, et al. Moxifloxacin (MXF) vs. amoxicillin/ clavulanic acid (AMC) in acute exacerbations of COPD (AECOPD): results of a large clinical trial with a novel endpoint. Respirology 2011;16(Suppl 2):195.

Wilson 2012 \{published data only\}

Wilson R, Anzueto A, Miravitlles M, Arvis P, Alder J, Haverstock D, et al. Moxifloxacin versus amoxicillin/ clavulanic acid in outpatient acute exacerbations of COPD: MAESTRAL results. European Respiratory Journal 2012;40: $17-27$.

Zapulla 1988 \{published data only\}

Zappulla G, Baratelli E, Bettini R, Mamolo G, Quadrelli C, Piccinelli M. Clinical evaluation of the efficacy and tolerability of 2 acyl-ureido-penicillins (mezlocillin and piperacillin) in the treatment of chronic bronchitis during acute phase [Valutazione clinica dell'efficacia e della

tollerabilita di due acil-ureido-penicilline (Mezlocillina e Piperacillina) nel trattamento delle bronchiti croniche 
riacutizzate]. Archivio Monaldi Per Le Malattie Del Torace 1988;43(3):279-88.

\section{Zervos 2005 \{published data only\}}

Zervos M, Breen JD, Jogensen D, Goodrich JM. Azithromycin microspheres (AZ-M) are as effective as levofloxacin (LEV) in subjects with moderate to very severe COPD. Infectious Diseases in Clinical Practice 2005;13: $115-21$.

\section{References to ongoing studies}

\section{NCT01091493 \{published data only\}}

Utility of Antibiotic Treatment in Non-purulent Exacerbations of Chronic Obstructive Pulmonary Disease: a Double Blinded, Randomized, Placebo-controlled Trial of Security and Efficacy (AEPOC-ATB). Ongoing study July 2010.

\section{Additional references}

\section{Bafadhel 2011}

Bafadhel M, McKenna S, Terry S, Mistry V, Reid C, Haldar P, et al. Acute exacerbations of COPD: identification of biological clusters and their biomarkers. American Journal of Respiratory Critical Care Medicine 2011;184(6):662-71.

Daniels 2010b

Daniels JM, Schoorl M, Snijders D, Knol DL, Lutter R, Jansen HM, et al. Procalcitonin vs C-reactive protein as predictive markers of response to antibiotic therapy in acute exacerbations of COPD. Chest 2010;138(5):1108-15.

\section{Garcia-Aymerich 2011}

Garcia-Aymerich J, Gómez FP, Benet M, Farrero E, Basagaña X, Gayete À, et al. Identification and prospective validation of clinically relevant chronic obstructive pulmonary disease (COPD) subtypes. Thorax 2011;66(5): $430-7$.

GOLD 2011

Global Strategy for Diagnosis, Management, and Prevention of COPD, December 2011. www.goldcopd.org/guidelinesglobal-strategy-for-diagnosis-management.html. (accessed 23 October 2012).

\section{Guyatt 2011}

Guyatt G, Oxman AD, Akl E, Kunz R, Vist G, Brozek J, et al. GRADE guidelines 1. Introduction - GRADE evidence profiles and summary of findings tables. Journal of Clinical Epidemiology 2011;64(4):383-94.

\section{Higgins 2011}

Higgins JPT, Green S (editors). Cochrane Handbook for Systematic Reviews of Interventions Version 5.1.0 [March 2011]. The Cochrane Collaboration, 2011. Available from www.cochrane-handbook.org.

\section{Jones 2008}

Jones RC, Dickson-Spillmann M, Mather MJ, Marks D, Shackell BS. Accuracy of diagnostic registers and management of chronic obstructive pulmonary disease: the Devon primary care audit. Respiratory Research 2008;18(9): 62.

\section{NICE 2010}

National Institute for Health and Clinical Excellence (NICE). Management of chronic obstructive pulmonary disease in adults in primary and secondary care, 2010. guidance.nice.org.uk/CG101. (accessed 23 October 2012).

Patel 2002

Patel IS, Seemungal TA, Wilks M, Lloyd-Owen SJ, Donaldson GC, Wedzicha JA. Relationship between bacterial colonisation and the frequency, character, and severity of COPD exacerbations. Thorax 2002;57(9): 759-64.

\section{Pretto 2012}

Pretto JJ, McDonald VM, Wark PA, Hensley MJ. A multicentre audit of inpatient management of acute exacerbations of COPD: comparison with clinical guidelines. Internal Medicine Journal 2012;42(4):380-7.

Puhan 2007

Puhan MA, Vollenweider D, Latshang T, Steurer J, SteurerStey C. Exacerbations of chronic obstructive pulmonary disease: when are antibiotics indicated? A systematic review. Respiratory Research 2007;4(8):30.

Puhan 2008

Puhan MA, Vollenweider D, Steurer J, Bossuyt PM, Ter Riet G. Where is the supporting evidence for treating mild to moderate chronic obstructive pulmonary disease exacerbations with antibiotics? A systematic review. $B M C$ Medicine 2008;6:28.

RevMan 2011 [Computer program] The Nordic Cochrane Centre, The Cochrane Collaboration. Review Manager (RevMan). Version 5.1. Copenhagen: The Nordic Cochrane Centre, The Cochrane Collaboration, 2011

\section{Rodriguez-Roisin 2000}

Rodriguez-Roisin R. Toward a consensus definition for COPD exacerbations. Chest 2000;117(5 Suppl 2): 398S-401S.

\section{Saint 1995}

Saint S, Bent S, Vittinghoff E, Grady D. Antibiotics in chronic obstructive pulmonary disease exacerbations. A meta-analysis. JAMA 1995;273(12):957-60.

\section{Schuetz 2012}

Schuetz P, Müller B, Christ-Crain M, Stolz D, Tamm M, Bouadma L, et al. Procalcitonin to initiate or discontinue antibiotics in acute respiratory tract infections. Cochrane Database of Systematic Reviews 2012, Issue 9. [DOI: 10.1002/14651858.CD007498]

\section{Seemungal 2001}

Seemungal T, Harper-Owen R, Bhowmik A, Moric I, Sanderson G, Message $S$, et al. Respiratory viruses, symptoms, and inflammatory markers in acute exacerbations and stable chronic obstructive pulmonary disease. American Journal of Respiratory Critical Care Medicine 2001;164(9): 1618-23.

\section{Sethi 2004}

Sethi S. Bacteria in exacerbations of chronic obstructive pulmonary disease: phenomenon or epiphenomenon? 
Proceedings of the American Thoracic Society; 2004 May

21-26; Orlando, FL. 2004:109-14.

\section{WHO factsheet no. 194}

World Health Organization. Antimicrobial resistance,

2012. www.who.int/mediacentre/factsheets/fs194/en.

(accessed 24 October 2012).

\section{References to other published versions of this review}

\section{Ram 2006}

Ram FS, Rodriguez-Roisin R, Granados-Navarrete

A, Garcia-Aymerich J, Barnes NC. Antibiotics for exacerbations of chronic obstructive pulmonary disease.

Cochrane Database of Systematic Reviews 2006, Issue 2.

[DOI: 10.1002/14651858.CD004403.pub2]

* Indicates the major publication for the study 


\section{CHARACTERISTICS OF STUDIES}

\section{Characteristics of included studies [ordered by study ID]}

\section{ABC 2009}

\begin{tabular}{ll}
\hline Methods & RCT \\
\hline Participants & $\begin{array}{l}\text { Participants: outpatients seen by chest physicians received antibiotic or placebo for mod- } \\
\text { erately severe exacerbations } \\
\text { Inclusion criteria: clinical diagnosis of COPD (GOLD criteria), current or ex-smoker, } \\
\text { aged } 40 \text { to } 80 \text { years, presenting as an outpatient with signs and symptoms of an exac- } \\
\text { erbation (change in dyspnoea, sputum volume and colour, and cough), able to produce } \\
\text { sputum sample, } 1 \text { or } 2 \text { of: positive sputum Gram's stain, clinically relevant decrease in } \\
\text { lung function or } \geq 2 \text { exacerbations in the previous year } \\
\text { Exclusion criteria: pneumonia, exacerbation or use of antibiotics or prednisolone } 4 \text { weeks } \\
\text { prior to enrolment (except } \leq 5 \text { mg prednisolone), other disease influencing lung function, } \\
\text { maintenance antibiotics, hypersensitivity to amoxicillin-clavulanic acid, serious medical } \\
\text { or psychiatric co-morbidity, uncontrolled diabetes mellitus, home oxygen therapy } \\
\text { Baseline demographics: } 35 \text { patients included; mean age } 67 \text { years; } 60 \% \text { male; mean FEV } V_{1} / \\
\text { FVC } 40 \% \\
\text { Spirometrically confirmed COPD: yes } \\
\text { Severity of exacerbation: moderate }\end{array}$ \\
\hline
\end{tabular}

Interventions

Follow-up: 28 days for primary outcome and 4 months for new exacerbations

Treatment group: amoxicillin-clavulanic acid $1.5 \mathrm{~g} /$ day for 7 days and oral prednisolone $30 \mathrm{mg}$ for 7 days

Control group: placebo for 7 days and oral prednisolone $30 \mathrm{mg}$ for 7 days

Outcomes

Resolution of exacerbation (patient reported symptom diary)

Relapses of exacerbations within 28 days

Chronic respiratory questionnaire

Clinical COPD questionnaire

Notes -

Risk of bias

Bias

Authors' judgement Support for judgement

Random sequence generation (selection Low risk bias)

\begin{tabular}{l|l|l} 
Allocation concealment (selection bias) & Unclear risk & Not described \\
\hline $\begin{array}{l}\text { Blinding of participants and personnel } \\
\text { (performance bias) } \\
\text { All outcomes }\end{array}$ & Low risk & "Double-blind" \\
\hline
\end{tabular}




\begin{tabular}{|c|c|c|}
\hline $\begin{array}{l}\text { Blinding of outcome assessment (detection } \\
\text { bias) } \\
\text { All outcomes }\end{array}$ & Unclear risk & Insufficient information to permit judgment of yes or no \\
\hline Intention-to- & Low risk & $\begin{array}{l}\text { All patients were analysed in the groups to which they were } \\
\text { randomised }\end{array}$ \\
\hline
\end{tabular}

\section{Allegra 1991}

\begin{tabular}{|c|c|c|}
\hline Methods & \multicolumn{2}{|l|}{ RCT } \\
\hline Participants & \multicolumn{2}{|c|}{$\begin{array}{l}\text { Participants: patients recruited from pulmonary departments received antibiotic or } \\
\text { placebo on an outpatient basis in case of self-reported worsening of respiratory symptoms } \\
\text { Inclusion criteria: aged }>40 \text { years, chronic bronchitis (defined as continuous cough and } \\
\text { expectoration, present for at least } 3 \text { months of the year, in more than } 2 \text { consecutive years) } \\
\text {, FEV } 1<80 \% \text { predicted } \\
\text { Exclusion criteria: reversible obstruction, cancer, liver insufficiency, renal insufficiency, } \\
\text { heart failure, pneumonia } \\
\text { Baseline demographics: } 335 \text { patients included; mean age } 63 \text { years; } 73 \% \text { male; mean } \\
\text { FEV } 1.37 \mathrm{~L} / \mathrm{s} \\
\text { Spirometrically confirmed COPD: yes } \\
\text { Severity of exacerbation: mild to moderate }\end{array}$} \\
\hline Interventions & \multicolumn{2}{|c|}{$\begin{array}{l}\text { Mean follow-up: } 5 \text { days } \\
\text { Treatment group: amoxicillin-clavulanic acid } 2 \text { g/day (oral) for } 5 \text { days } \\
\text { Control group: placebo for } 5 \text { days }\end{array}$} \\
\hline Outcomes & \multicolumn{2}{|c|}{$\begin{array}{l}\text { Treatment success/failure (patient-reported symptoms and clinical signs) at } 5 \text { days (not } \\
\text { analysed in this systematic review) } \\
\text { Dyspnoea (not analysed in this systematic review because data were not in format that } \\
\text { we could use) } \\
\text { Adverse events }\end{array}$} \\
\hline Notes & \multicolumn{2}{|c|}{$\begin{array}{l}\text { According to an author of the study (personal communication with Dr. Blasi, March } \\
\text { 2006) data after } 14 \text { days of follow-up were available but not published and not made } \\
\text { available for this review }\end{array}$} \\
\hline \multicolumn{3}{|l|}{ Risk of bias } \\
\hline Bias & Authors' judgement & Support for judgement \\
\hline $\begin{array}{l}\text { Random sequence generation (selection } \\
\text { bias) }\end{array}$ & Unclear risk & Not reported \\
\hline Allocation concealment (selection bias) & Unclear risk & Not reported \\
\hline
\end{tabular}




\section{Allegra 1991 (Continued)}

\begin{tabular}{l|l|l}
\hline $\begin{array}{l}\text { Blinding of participants and personnel } \\
\text { (performance bias) } \\
\text { All outcomes }\end{array}$ & Low risk & “Double-blind” \\
\hline $\begin{array}{l}\text { Blinding of outcome assessment (detection } \\
\text { bias) } \\
\text { All outcomes }\end{array}$ & Unclear risk & Not reported \\
\hline \begin{tabular}{l} 
Intention-to-treat-analysis \\
\hline
\end{tabular} & High risk & Only patients with complete follow-up were analysed \\
\hline
\end{tabular}

Alonso Martinez 1992

\begin{tabular}{ll} 
Methods & Randomised double-blinded placebo-controlled trial \\
\hline \multirow{2}{*}{ Participants } & Participants: patients admitted to hospital with exacerbation (increasing symptoms such \\
as dyspnoea, sputum volume or cough) of COPD \\
Inclusion criteria: clinical diagnosis of COPD at the time of hospital admission \\
Exclusion criteria: antibiotic treatment during the previous 2 weeks, left ventricular \\
failure, stroke, pneumonia, pneumothorax, non-cutaneous cancer, coma, temperature $>$ \\
$38^{\circ} \mathrm{C}$, psychological disorders related to COPD \\
Baseline demographics: 90 patients included; mean age 68 years, $84 \%$ male, mean FEV 1 \\
\% predicted $(\mathrm{SD}) 29.98 \%(11.07)$ \\
Spirometrically confirmed COPD: yes \\
Severity of exacerbation: severe
\end{tabular}

Interventions $\quad$ Mean follow-up: 7.2 days

Treatment group: trimethoprim-sulphamethoxazole $1.9 \mathrm{~g} /$ day or amoxicillin/clavulanic acid $1.9 \mathrm{~g} /$ day orally for 8 days

Control group: placebo for 8 days

$\begin{array}{ll}\text { Outcomes } & \text { Length of hospital stay } \\ \text { Treatment success (use of additional antibiotics) } \\ \text { Re-exacerbations (in } 3 \text { months - not analysed in this systematic review) }\end{array}$

Notes

All patients were treated with theophylline, inhaled bronchodilators and oxygen. If the numerical score was high or $\mathrm{FEV}_{1}<40 \%$ they received, 6-methylprednisolone $0.75 \mathrm{mg}$ / $\mathrm{kg} /$ day

\section{Risk of bias}

Random sequence generation (selection Low risk bias)

Allocation concealment (selection bias) Low risk
Arithmetic combination

Through hospital pharmacy 


\section{Alonso Martinez 1992 (Continued)}

\begin{tabular}{l|l|l}
\hline $\begin{array}{l}\text { Blinding of participants and personnel } \\
\text { (performance bias) } \\
\text { All outcomes }\end{array}$ & Low risk & “Double-blind" \\
\hline $\begin{array}{l}\text { Blinding of outcome assessment (detection } \\
\text { bias) } \\
\text { All outcomes }\end{array}$ & Unclear risk & Not enough information provided \\
\hline \begin{tabular}{l} 
Intention-to-treat-analysis \\
\hline
\end{tabular} & Low risk & Analysed as intention to treat \\
\hline
\end{tabular}

\section{Anthonisen 1987}

\begin{tabular}{|c|c|}
\hline Methods & Randomised double-blinded placebo-controlled trial \\
\hline Participants & $\begin{array}{l}\text { Participants: } 173 \text { patients were recruited from the community with stable COPD. } 116 \\
\text { developed exacerbations (increased dyspnoea, sputum volume or sputum purulence) and } \\
\text { each time was randomly assigned to receive antibiotics or placebo } \\
\text { Inclusion criteria: aged }>35 \text { years; clinical diagnosis of COPD, not asthma; FEV }{ }_{1} \text { and } \\
\text { FVC }<70 \% \text { predicted, TLC }>80 \% \\
\text { Exclusion criteria: if FEV } \mathrm{F}_{1} \text { increased to } 80 \% \text { of predicted post bronchodilator use; other } \\
\text { disease serious enough to influence their quality of life or clinical course (e.g. cancer, } \\
\text { left ventricular failure, stroke) or other disease likely to require antibiotics (e.g. recurrent } \\
\text { sinusitis or UTI) } \\
\text { Baseline demographics: } 116 \text { patients included; mean age } 67 \text { years, } 80 \% \text { male, mean } \\
\text { FEV } 1 \text { predicted (SD): } 33.9 \% \text { (13.7) } \\
\text { Spirometrically confirmed COPD: yes } \\
\text { Severity of exacerbation: mild to moderate }\end{array}$ \\
\hline Interventions & $\begin{array}{l}\text { Follow-up: } 21 \text { days } \\
\text { Treatment group: trimethoprim/sulphamethoxazole } 1.9 \mathrm{~g} / \text { day or amoxicillin } 1 \mathrm{~g} / \text { day or } \\
\text { doxycycline } 0.1 \text { to } 0.2 \mathrm{~g} / \text { day orally for } 10 \text { days } \\
\text { Control group: placebo for } 10 \text { days }\end{array}$ \\
\hline
\end{tabular}

Outcomes

Treatment failure (patient-reported symptoms)

Side effects (\% of exacerbations with side effects)

Notes

The analysis was based on number of patients with first exacerbations (only first exacerbation). Side effects were not analysed as they were expresses as $\%$ of all exacerbations

Risk of bias

Bias

Random sequence generation (selection Low risk bias)
Unclear risk

Not reported
Support for judgement

Random schedule 
Anthonisen 1987 (Continued)

Blinding of participants and personnel Low risk (performance bias)

All outcomes

Blinding of outcome assessment (detection Low risk bias)

All outcomes
Low risk
"Neither patients nor medical staff knew which medication was active"

Intention-to-treat-analysis

Analysed as intention to treat

Berry 1960

\begin{tabular}{|c|c|c|}
\hline Methods & \multicolumn{2}{|l|}{ RCT } \\
\hline Participants & \multicolumn{2}{|c|}{$\begin{array}{l}\text { Participants: patients at general practitioner visit for new or aggravated respiratory symp- } \\
\text { toms } \\
\text { Inclusion criteria: chronic bronchitis (persistent or recurrent cough with diffuse physical } \\
\text { signs in the chest, in which X-ray had excluded other disease) with exacerbation (wors- } \\
\text { ening characterised by } 1 \text { or more of the following: increased cough, increased volume of } \\
\text { sputum, increased purulence of sputum, increased breathlessness or fever) } \\
\text { Exclusion criteria: none } \\
\text { Baseline demographics: } 58 \text { patients included; mean age } 59 \text { years, } 53 \% \text { male, FEV } \mathrm{F}_{1} \text { not } \\
\text { reported } \\
\text { Spirometrically confirmed COPD: no } \\
\text { Severity of exacerbation: mild to moderate }\end{array}$} \\
\hline Interventions & \multicolumn{2}{|c|}{$\begin{array}{l}\text { Mean follow-up: } 14 \text { days } \\
\text { Treatment group: oxytetracycline } 1 \mathrm{~g} / \text { day (oral) for } 5 \text { days } \\
\text { Control group: placebo for } 5 \text { days }\end{array}$} \\
\hline Outcomes & \multicolumn{2}{|c|}{ Treatment success/failure (patient reported) } \\
\hline Notes & \multicolumn{2}{|c|}{$\begin{array}{l}\text { Patients with severe exacerbations were not included because antibiotics were deemed } \\
\text { indispensable }\end{array}$} \\
\hline \multicolumn{3}{|l|}{ Risk of bias } \\
\hline Bias & Authors' judgement & Support for judgement \\
\hline $\begin{array}{l}\text { Random sequence generation (selection } \\
\text { bias) }\end{array}$ & Low risk & Table of random numbers \\
\hline Allocation concealment (selection bias) & Low risk & Identical bottles, key to numbers was kept by another person \\
\hline $\begin{array}{l}\text { Blinding of participants and personnel } \\
\text { (performance bias) } \\
\text { All outcomes }\end{array}$ & Low risk & Identical bottles and capsules \\
\hline
\end{tabular}

Antibiotics for exacerbations of chronic obstructive pulmonary disease (Review) 
Berry 1960 (Continued)

\begin{tabular}{l|l|l}
$\begin{array}{l}\text { Blinding of outcome assessment (detection } \\
\text { bias) } \\
\text { All outcomes }\end{array}$ & Low risk & Practitioners were blinded \\
\hline Intention-to-treat-analysis & High risk & Patients with possible toxic effects from drugs were excluded \\
\hline
\end{tabular}

\section{Daniels 2010}

\begin{tabular}{ll}
\hline Methods & RCT \\
\hline Participants & Participants: hospitalised patients with acute exacerbations of COPD \\
& Inclusion criteria: aged $>45$ years, diagnosis of COPD (GOLD criteria), acute exacer- \\
& bation (Anthonisen 1 and 2$)$ \\
& Exclusion criteria: inability to take oral medication, fever $\left(>38.5^{\circ} \mathrm{C}\right)$, antibiotic treat- \\
& ment for $>24$ hours, extensive treatment with corticosteroids $(>30$ mg $>4$ days), his- \\
& tory of severe exacerbation requiring mechanical ventilation, lung malignancy, other \\
& infectious disease requiring antibiotic therapy, heart failure $(\mathrm{NYHA}$ III-IV), apparent \\
& immunodeficiency, impaired renal function (creatinine clearance $\left.<20 \mathrm{~mL} / \mathrm{min}^{\circ}\right)$ \\
& Baseline demographics: 223 patients included; 265 exacerbations; mean age 72 years; \\
& $59.6 \%$ male; mean FEV 1 (SD) doxycycline group $43.9 \%(17.2 \%)$, placebo group 46. \\
& $9 \%(18.5 \%)$ \\
& Spirometrically confirmed COPD: yes \\
& Severity of exacerbation: moderate to severe \\
\hline
\end{tabular}

Interventions

Mean follow-up: 30 days

Treatment group: 7-day course of oral doxycycline, IV prednisolone taper

Control group: 7-day course of placebo, IV prednisolone taper

\begin{tabular}{ll}
\hline Outcomes & $\begin{array}{l}\text { Primary outcome: clinical response on day } 30 \text { (success/failure) } \\
\text { Secondary outcome: clinical success day } 10, \text { dyspnoea score, adverse events, mortality }\end{array}$ \\
\hline Notes & Analysis based on the number of exacerbations and patients (mortality)
\end{tabular}

Risk of bias

Bias

Authors' judgement Support for judgement

Random sequence generation (selection Low risk Computer generated bias)

$\begin{array}{ll}\text { Allocation concealment (selection bias) Low risk } & \begin{array}{l}\text { "Allocation sequence was kept in a safe at the hospital phar- } \\ \text { macy"; "study medication was delivered in pre-numbered con- } \\ \text { tainers" }\end{array}\end{array}$

Blinding of participants and personnel Low risk

"Double-blind" (performance bias)

All outcomes

Antibiotics for exacerbations of chronic obstructive pulmonary disease (Review) 
Daniels 2010 (Continued)

\begin{tabular}{l|l|l}
\hline $\begin{array}{l}\text { Blinding of outcome assessment (detection } \\
\text { bias) } \\
\text { All outcomes }\end{array}$ & Unclear risk & Not described (only “double-blind”) \\
\hline $\begin{array}{l}\text { Intention-to-treat-analysis } \\
\text { Low risk }\end{array}$ & $\begin{array}{l}\text { Analysed as intention to treat and per-protocol (we used only } \\
\text { intention to treat) }\end{array}$ \\
\hline
\end{tabular}

\section{Elmes 1957}

\begin{tabular}{ll}
\hline Methods & RCT \\
\hline Participants & $\begin{array}{l}\text { Participants: patients were instructed to take antibiotic or placebo without a doctor visit } \\
\text { as soon as new or aggravated respiratory symptoms were present } \\
\text { Inclusion criteria: aged }<65 \text { years, regular employment, productive winter cough for }> \\
3 \text { years, during which time they had at least } 2 \text { illnesses with purulent sputum, causing } \\
\text { loss of time from work } \\
\text { Exclusion criteria: other disabling disease } \\
\text { Baseline demographics: } 88 \text { patients included; mean } 54 \text { age years; } 84 \% \text { male; FEV } 1 \text { not } \\
\text { stated } \\
\text { Spirometrically confirmed COPD: no } \\
\text { Severity of exacerbation: mild to moderate }\end{array}$ \\
\hline Interventions & $\begin{array}{l}\text { Mean follow-up: } 17 \text { days } \\
\text { Treatment group: oxytetracycline } 1 \text { g/day orally for } 5 \text { to } 7 \text { days } \\
\text { Control group: placebo for } 5 \text { to } 7 \text { days }\end{array}$ \\
\hline Outcomes & Treatment success/failure (need for further antibiotics) \\
Time off work \\
Side effects
\end{tabular}

Risk of bias

Bias

Authors' judgement Support for judgement

Random sequence generation (selection Low risk bias)

\begin{tabular}{|c|c|c|}
\hline Allocation concealment (selection bias) & Low risk & "Key list was held by the hospitals pharmacist" \\
\hline $\begin{array}{l}\text { Blinding of participants and personnel } \\
\text { (performance bias) } \\
\text { All outcomes }\end{array}$ & Low risk & $\begin{array}{l}\text { "Dummy tablets... neither doctors nor patients knowing which } \\
\text { was which" }\end{array}$ \\
\hline $\begin{array}{l}\text { Blinding of outcome assessment (detection } \\
\text { bias) } \\
\text { All outcomes }\end{array}$ & Low risk & $\begin{array}{l}\text { "Dummy tablets... neither doctors nor patients knowing which } \\
\text { was which" }\end{array}$ \\
\hline
\end{tabular}


Elmes 1957 (Continued)

\begin{tabular}{|c|c|}
\hline Intention-to-treat-analysis & Analysed as intention to treat \\
\hline \multicolumn{2}{|l|}{ Fear 1962} \\
\hline Methods & RCT \\
\hline Participants & $\begin{array}{l}\text { Participants: patients recruited from bronchitis and asthma clinics received antibiotic or } \\
\text { placebo as an outpatient based on case of self-reported worsening of respiratory symptoms } \\
\text { Inclusion criteria: aged } 20 \text { to } 65 \text { years, winter cough and sputum for at least } 3 \text { years, with } \\
\text { shortness of breath on effort without evidence of other cause; some degree of disability } \\
\text { from the bronchitis (e.g. limitation of normal activity, loss of time at work) } \\
\text { Exclusion criteria: none } \\
\text { Baseline demographics: } 62 \text { patients included; mean age, } \% \text { male and } \mathrm{FEV}_{1} \text { not stated } \\
\text { Spirometrically confirmed COPD: no } \\
\text { Severity of exacerbation: mild to moderate }\end{array}$ \\
\hline Interventions & $\begin{array}{l}\text { Mean follow-up: } 14 \text { days } \\
\text { Treatment group: oxytetracycline } 1 \mathrm{~g} / \text { day (oral) for } 7 \text { days } \\
\text { Control group: placebo for } 7 \text { days }\end{array}$ \\
\hline Outcomes & $\begin{array}{l}\text { Improvement of symptoms (not analysed in this systematic review) } \\
\text { Days of illness (not analysed in this systematic review) }\end{array}$ \\
\hline Notes & Second trial of the article \\
\hline
\end{tabular}

Risk of bias

Bias

Authors' judgement Support for judgement

Random sequence generation (selection Low risk List of random numbers bias)

\begin{tabular}{|c|c|c|}
\hline Allocation concealment (selection bias) & Low risk & "Similar to that used by Elmes 1957" "identical appearance" \\
\hline $\begin{array}{l}\text { Blinding of participants and personnel } \\
\text { (performance bias) }\end{array}$ & Low risk & "Double blind" "identical appearance" \\
\hline
\end{tabular}

Blinding of outcome assessment (detection Unclear risk $\quad$ Not enough information
bias)

All outcomes

\begin{tabular}{|c|c|c|}
\hline Intention-to-treat-analysis & Low risk & Analysed as intention to treat \\
\hline
\end{tabular}


Jørgensen 1992

\begin{tabular}{|c|c|c|}
\hline Methods & \multicolumn{2}{|c|}{ Randomised double-blind placebo-controlled trial } \\
\hline Participants & \multicolumn{2}{|c|}{$\begin{array}{l}\text { Participants: patients with general practitioner visits for new or aggravated symptoms } \\
\text { Inclusion criteria: aged }>18 \text { years with acute exacerbation (subjective worsening owing to } \\
\text { change in sputum (increased volume, change of viscosity or colour) possibly accompanied } \\
\text { by cough or dyspnoea, lasting for more than } 3 \text { days or chronic bronchitis (defined as } \\
\text { continuous cough and expectoration, present for at least } 3 \text { months of the year, in more } \\
\text { than } 2 \text { consecutive years) } \\
\text { Exclusion criteria: pneumonia (on auscultation or X-ray), temperature }>38.5^{\circ} \mathrm{C} \text {, heart } \\
\text { rate > } 100 \text { beats/min, antibiotics within the previous } 7 \text { days, pregnancy, allergy to peni- } \\
\text { cillin, uncompensated heart disease, treatment with oral corticosteroids or immunosup- } \\
\text { pressants } \\
\text { Baseline demographics: } 270 \text { patients included; mean age } 60 \text { years, } 43 \% \text { male. } \mathrm{FEV}_{1} \text { not } \\
\text { stated } \\
\text { Spirometrically confirmed COPD: no } \\
\text { Severity of exacerbation: mild to moderate }\end{array}$} \\
\hline Interventions & \multicolumn{2}{|c|}{$\begin{array}{l}\text { Mean follow-up: } 8 \text { days } \\
\text { Treatment group: amoxicillin } 1.5 \mathrm{~g} \text { (oral) for } 7 \text { days } \\
\text { Control group: placebo for } 7 \text { days }\end{array}$} \\
\hline Outcomes & \multicolumn{2}{|c|}{$\begin{array}{l}\text { Treatment failure (patient-reported symptoms) } \\
\text { Adverse events }\end{array}$} \\
\hline Notes & \multicolumn{2}{|l|}{-} \\
\hline \multicolumn{3}{|l|}{ Risk of bias } \\
\hline Bias & Authors' judgement & Support for judgement \\
\hline $\begin{array}{l}\text { Random sequence generation (selection } \\
\text { bias) }\end{array}$ & Unclear risk & $\begin{array}{l}\text { "Patients were randomised to treatment or } \\
\text { placebo", with no more details }\end{array}$ \\
\hline Allocation concealment (selection bias) & Unclear risk & Not reported \\
\hline $\begin{array}{l}\text { Blinding of participants and personnel } \\
\text { (performance bias) } \\
\text { All outcomes }\end{array}$ & Low risk & "Double blind" \\
\hline $\begin{array}{l}\text { Blinding of outcome assessment (detection } \\
\text { bias) } \\
\text { All outcomes }\end{array}$ & Unclear risk & Not enough information \\
\hline Intention-to-treat-analysis & Low risk & Analysed as intention to treat \\
\hline
\end{tabular}


Llor 2012

Methods

Participants
Randomised double-blind, placebo-controlled trial

Participants: recruited from 13 primary care centres

Inclusion criteria: aged $>40$ years, diagnosis of mild to moderate COPD (smoking history $>10$ pack-years, ratio of post-bronchodilator $\mathrm{FEV}_{1}: \mathrm{FVC}$ of $<70 \%$, post-bronchodilator $\mathrm{FEV}_{1}>50 \%$ of the predicted value), presence of an exacerbation (at least 1 of the following: increase of dyspnoea, increase in sputum volume, sputum purulence, or a combination)

Exclusion criteria: antibiotic use in the previous 2 weeks, bronchial asthma, cystic fibrosis, bronchiectasis of origin other than COPD, active neoplasm, tracheotomy, need for hospital admission, immunosuppression, hypersensitivity to beta-lactams, clavulanate or lactose, institutionalisation, unable to provide informed consent

Baseline demographics: 310 patients included; mean age 68 years, $81 \%$ male, mean $\mathrm{FEV}_{1} / \mathrm{FVC} 62 \%$

Spirometrically confirmed COPD: yes

Severity of exacerbation: mild to moderate

Interventions

Mean follow-up: 20 days

Treatment group: amoxicillin/clavulanate 500/125 mg 3 times daily (oral) for 8 days

Control group: placebo for 8 days

Outcomes

Primary outcome: clinical cure/improvement or failure at the end of therapy visit (days 9 to 11 , physician assessed)

Secondary outcome: clinical cure/improvement or failure at follow-up visit at day 20

Re-exacerbations (in 1 year - not analysed in this systematic review)

Adverse events

Notes

Risk of bias

\begin{tabular}{|c|c|c|}
\hline Bias & Authors' judgement & Support for judgement \\
\hline $\begin{array}{l}\text { Random sequence generation (selection } \\
\text { bias) }\end{array}$ & Low risk & Random-number table \\
\hline Allocation concealment (selection bias) & Unclear risk & Not adequately described \\
\hline $\begin{array}{l}\text { Blinding of participants and personnel } \\
\text { (performance bias) } \\
\text { All outcomes }\end{array}$ & Low risk & $\begin{array}{l}\text { Patients, investigators and data assessors } \\
\text { were masked to treatment allocation }\end{array}$ \\
\hline $\begin{array}{l}\text { Blinding of outcome assessment (detection } \\
\text { bias) } \\
\text { All outcomes }\end{array}$ & Low risk & $\begin{array}{l}\text { Patients, investigators and data assessors } \\
\text { were masked to treatment allocation }\end{array}$ \\
\hline Intention-to-treat-analysis & Low risk & Analysed as intention to treat \\
\hline
\end{tabular}

Antibiotics for exacerbations of chronic obstructive pulmonary disease (Review) 


\begin{tabular}{|c|c|}
\hline Methods & Randomised double-blind, placebo-controlled trial \\
\hline Participants & $\begin{array}{l}\text { Participants: patients admitted to hospital with exacerbation of COPD } \\
\text { Inclusion criteria: at the time of a hospital admission: increase in symptoms (cough, } \\
\text { dyspnoea, and volume and purulence of sputum) } \\
\text { Exclusion criteria: evidence of parenchymal consolidation on chest X-ray or of other } \\
\text { pulmonary or cardiac disease } \\
\text { Baseline demographics: } 19 \text { patients included, mean age } 67 \text { years, } \% \text { male, } \mathrm{FEV}_{1} \text { not } \\
\text { stated } \\
\text { Spirometrically confirmed COPD: no } \\
\text { Severity of exacerbation: severe }\end{array}$ \\
\hline Interventions & $\begin{array}{l}\text { Mean follow-up: } 13 \text { days } \\
\text { Treatment group: cefaclor } 1.5 \mathrm{~g} / \mathrm{day} \text { (oral) for } 8 \text { days } \\
\text { Control group: placebo for } 8 \text { days }\end{array}$ \\
\hline Outcomes & Length of hospital stay \\
\hline Notes & Research letter to the editor \\
\hline
\end{tabular}

Risk of bias

\begin{tabular}{l|ll}
\hline Bias & Authors' judgement & Support for judgement \\
\hline $\begin{array}{l}\text { Random sequence generation (selection } \\
\text { bias) }\end{array}$ & Unclear risk & Not reported \\
\hline $\begin{array}{l}\text { Allocation concealment (selection bias) } \\
\text { Blinding of participants and personnel } \\
\text { (performance bias) } \\
\text { All outcomes }\end{array}$ & Unclear risk & Not reported \\
\hline $\begin{array}{l}\text { Blinding of outcome assessment (detection } \\
\text { bias) } \\
\text { All outcomes }\end{array}$ & Unclear risk & Not described (“double blind”) \\
\hline \begin{tabular}{l} 
Intention-to-treat-analysis \\
\hline
\end{tabular} & Low risk & Not described (“double blind”) \\
\hline
\end{tabular}

Nouira 2001

\begin{tabular}{l|l}
\hline Methods & Randomised, double-blind, placebo-controlled trial \\
\hline Participants & $\begin{array}{l}\text { Participants: patients admitted to medical ICU with exacerbation of COPD and need } \\
\text { for mechanical ventilation } \\
\text { Inclusion criteria: aged }>40 \text { years; COPD diagnosed on the basis of clinical history, } \\
\text { physical examination, and chest radiograph; acute respiratory failure requiring mechan- } \\
\text { ical ventilation within the first } 24 \mathrm{~h} \text { of admission } \\
\text { Exclusion criteria: antimicrobial treatment in the previous } 10 \text { days, alveolar infiltrates on }\end{array}$
\end{tabular}


chest X-rays, previously enrolled in the study. Known history of asthma or bronchiectasis, allergy to quinolone derivatives, pregnancy or breast feeding, terminally ill or immunocompromised, hepatic disease or severe renal impairment, gastrointestinal disease that could affect drug absorption, concomitant infection requiring systemic antibacterial therapy

Baseline demographics: 93 patients included; mean age 66 years, $90 \%$ male, mean $\mathrm{FEV}_{1}$ $0.77 \mathrm{~L} / \mathrm{s}$

Spirometrically confirmed COPD: no

Severity of exacerbation: severe

\section{Interventions}

Mean follow-up: 10 days

All patients were monitored until their discharge from hospital

Treatment group: ofloxacin $400 \mathrm{mg} /$ day (oral) for 10 days

Control group: placebo for 10 days

\begin{tabular}{|c|c|c|}
\hline Outcomes & \multicolumn{2}{|c|}{$\begin{array}{l}\text { Mortality } \\
\text { Treatment failure (need for additional antibiotics and death combined) } \\
\text { Length of hospital stay } \\
\text { Adverse events }\end{array}$} \\
\hline Notes & - & \\
\hline \multicolumn{3}{|l|}{ Risk of bias } \\
\hline Bias & Authors' judgement & Support for judgement \\
\hline $\begin{array}{l}\text { Random sequence generation (selection } \\
\text { bias) }\end{array}$ & Low risk & $\begin{array}{l}\text { Patients were randomly assigned to treat- } \\
\text { ment or placebo using random numbers }\end{array}$ \\
\hline Allocation concealment (selection bias) & Low risk & $\begin{array}{l}\text { All drugs and placebo packages were pre- } \\
\text { pared and numbered by the hospital phar- } \\
\text { macy and were used consecutively. Assign- } \\
\text { ments of patients were placed in closed en- } \\
\text { velopes with identification numbers that } \\
\text { were stored in the ICU }\end{array}$ \\
\hline $\begin{array}{l}\text { Blinding of participants and personnel } \\
\text { (performance bias) } \\
\text { All outcomes }\end{array}$ & Low risk & Identical appearance of the medication \\
\hline $\begin{array}{l}\text { Blinding of outcome assessment (detection } \\
\text { bias) } \\
\text { All outcomes }\end{array}$ & Low risk & $\begin{array}{l}\text { All study investigators and hospital staff } \\
\text { were masked to the treatment status until } \\
\text { data completion }\end{array}$ \\
\hline Intention-to-treat-analysis & Low risk & Analysed as intention to treat \\
\hline
\end{tabular}




\begin{tabular}{|c|c|c|}
\hline Methods & \multicolumn{2}{|c|}{ Randomised, double-blind, controlled trial } \\
\hline Participants & \multicolumn{2}{|c|}{$\begin{array}{l}\text { Participants: patients admitted to hospital with exacerbation (not defined) of COPD } \\
\text { Inclusion criteria: aged } 45 \text { to } 75 \text { years, chronic bronchitis (history of cough and expecto- } \\
\text { ration on most days during at least } 3 \text { consecutive months in each of } 2 \text { or more successive } \\
\text { years) } \\
\text { Exclusion criteria: severe deformities of the spine or chest, localised or generalised specific } \\
\text { lung disease, signs of cardiac insufficiency } \\
\text { Baseline demographics: } 19 \text { patients included; mean age } 62 \text { years, } 53 \% \text { male } \\
\text { Spirometrically confirmed COPD: no } \\
\text { Severity of exacerbation: severe }\end{array}$} \\
\hline Interventions & \multicolumn{2}{|c|}{$\begin{array}{l}\text { Mean follow-up: } 10 \text { days } \\
\text { Treatment group: chloramphenicol } 2 \mathrm{~g} / \text { day for } 10 \text { day } \\
\text { Control group: placebo for } 10 \text { day }\end{array}$} \\
\hline Outcomes & \multicolumn{2}{|c|}{$\begin{array}{l}\text { Mortality } \\
\text { Patient-reported well-being }\end{array}$} \\
\hline Notes & \multicolumn{2}{|l|}{-} \\
\hline \multicolumn{3}{|l|}{ Risk of bias } \\
\hline Bias & Authors' judgement & Support for judgement \\
\hline $\begin{array}{l}\text { Random sequence generation (selection } \\
\text { bias) }\end{array}$ & Low risk & Table of random numbers \\
\hline Allocation concealment (selection bias) & Unclear risk & Not reported \\
\hline $\begin{array}{l}\text { Blinding of participants and personnel } \\
\text { (performance bias) } \\
\text { All outcomes }\end{array}$ & Unclear risk & Patients: yes; personnel: no \\
\hline $\begin{array}{l}\text { Blinding of outcome assessment (detection } \\
\text { bias) } \\
\text { All outcomes }\end{array}$ & High risk & $\begin{array}{l}\text { Control group got a clinical examination } \\
\text { on day } 0\end{array}$ \\
\hline Intention-to-treat-analysis & High risk & $\begin{array}{l}\text { Drop-outs were not analysed (only per-pro- } \\
\text { tocol reported) }\end{array}$ \\
\hline
\end{tabular}

Pines 1968

\begin{tabular}{ll}
\hline Methods & Randomised, double-blinded, placebo-controlled trial \\
\hline Participants & $\begin{array}{l}\text { Participants: patients admitted to hospital with exacerbation of symptoms of chronic } \\
\text { bronchitis } \\
\text { Inclusion criteria: }>50 \text { years old, history of chronic bronchitis }>5 \text { years and a history } \\
\text { during the past } 6 \text { weeks of an exacerbation, male, moderately-to-severely illness on }\end{array}$ \\
\hline
\end{tabular}


admission (as judged by the receiving SHO), persistent purulent sputum and a PEFR < $200 \mathrm{~L} / \mathrm{min}$ (unless too ill to do so)

Exclusion criteria: allergy to penicillin, asthma, extensive bronchiectasis, active tuberculosis, lung cancer, sputum eosinophilia (> 10\%) or blood urea $>60 \mathrm{mg} / 100 \mathrm{~mL}$

Baseline demographics: 30 patients, mean age 68 years, $100 \%$ males, FEV1 not reported Spirometrically confirmed COPD: No

Severity of exacerbation: severe

\begin{tabular}{l|l} 
Interventions & $\begin{array}{l}\text { Mean follow-up: } 14 \text { days } \\
\text { Treatment group: penicillin } 6 \text { million u } \\
\text { parenterally for } 7 \text { days } \\
\text { Control group: placebo for } 14 \text { days }\end{array}$ \\
\hline Outcomes & $\begin{array}{l}\text { Treatment failure (physician reported) } \\
\text { Mortality }\end{array}$ \\
\hline Notes & Pilot trial of the paper \\
\hline
\end{tabular}

Risk of bias

Bias

Authors' judgement

Support for judgement

Random sequence generation (selection Low risk

Fisher and Yate's tables

bias)

$\begin{array}{lll}\text { Allocation concealment (selection bias) Low risk } & \text { Sealed envelopes }\end{array}$

Blinding of participants and personnel Low risk (performance bias)

All outcomes

\begin{tabular}{l|l|l}
\hline $\begin{array}{l}\text { Blinding of outcome assessment (detection } \\
\text { bias) } \\
\text { All outcomes }\end{array}$ & Low risk & "blind assessors" \\
\hline \begin{tabular}{l} 
Intention-to-treat-analysis \\
\hline
\end{tabular} & Low risk & Analysed as intention to treat \\
\hline
\end{tabular}

Pines 1972

\begin{tabular}{ll} 
Methods & Randomised double-blinded controlled trial \\
\hline Participants & Participants: patients admitted to hospital with exacerbation of COPD \\
& $\begin{array}{l}\text { Inclusion criteria: aged }>60 \text { years old, history of chronic bronchitis }>5 \text { years and a } \\
\text { definite history during the previous } 6 \text { weeks of an exacerbation, male, failure of at least } 1\end{array}$ \\
& $\begin{array}{l}\text { previous treatment with antibiotics, moderately severely ill on admission (as judged by } \\
\text { the receiving SHO), persistent purulent sputum and PEFR }<200 \mathrm{~L} / \mathrm{min}\end{array}$ \\
& $\begin{array}{l}\text { Exclusion criteria: asthma, bronchiectasis, other pulmonary disease or sputum } \\
\text { eosinophilia }(>10 \%)\end{array}$
\end{tabular}


Pines 1972 (Continued)

Baseline demographics: 259 patients included, mean age 71 years, 100\% male, $\mathrm{FEV}_{1}$ not reported

Spirometrically confirmed COPD: no

Severity of exacerbation: severe

Mean follow-up: 12 days
Exacerbations were followed at the beginning and end of trial and 1 and 4 weeks later
Treatment groups 1 and 2 : tetracycline hydrochloride $2 \mathrm{~g} /$ day or chloramphenicol $2 \mathrm{~g} /$
day orally for 12 days
Control group: placebo for 12 days

Outcomes

Treatment failure (physician reported) day 12

Treatment failure (additional antibiotics) day 7 to 28

Mortality

Adverse events

Notes

Patients with very severe exacerbation were not included for ethical reasons

Risk of bias

Risk of bias

$\begin{array}{lll}\text { Bias } & \text { Authors' judgement } & \text { Support for judgement }\end{array}$

\begin{tabular}{l|l} 
Random sequence generation (selection Low risk & Fisher \& Yate's tables
\end{tabular}

bias)

Allocation concealment (selection bias) Low risk

The total course of capsules for each patient was put into a sealed bottle by an independent pharmacist

Blinding of participants and personnel Low risk

Identical capsules

(performance bias)

All outcomes

Blinding of outcome assessment (detection Low risk bias)

All outcomes

Intention-to-treat-analysis

Low risk

No withdrawals

Sachs 1995

Methods

RCT

Participants

Participants: patients with general practitioner visit for new or aggravated respiratory (increase in dyspnoea with or without sputum production) symptoms

Inclusion criteria: aged > 18 years, positive diagnosis of asthma or COPD made by a pulmonary physician during the previous 10 years

Exclusion criteria: daily use of oral corticosteroids or antimicrobial drugs, diabetes mel-

litus, alcoholism, history of pulmonary surgery or tuberculosis, severe bronchiectasis, a

Antibiotics for exacerbations of chronic obstructive pulmonary disease (Review)

Copyright $\odot 2012$ The Cochrane Collaboration. Published by John Wiley \& Sons, Ltd. 


\begin{tabular}{|c|c|c|}
\hline & \multicolumn{2}{|c|}{$\begin{array}{l}\text { psychiatric history } \\
\text { Baseline demographics: } 61 \text { patients included; mean age }-52 \text { years, } \% \text { male and mean } \\
\text { FEV }_{1} \text { not stated } \\
\text { Spirometrically confirmed COPD: unclear } \\
\text { Severity of exacerbation: mild to moderate }\end{array}$} \\
\hline Interventions & \multicolumn{2}{|c|}{$\begin{array}{l}\text { Mean follow-up: } 35 \text { days } \\
\text { Treatment group: amoxicillin } 1.5 \mathrm{~g} \text { or co-trimoxazole } 1.9 \mathrm{~g} / \text { day orally for } 7 \text { days } \\
\text { Control group: placebo for } 7 \text { days }\end{array}$} \\
\hline Outcomes & \multicolumn{2}{|c|}{ Treatment success/failure (patient reported symptoms) } \\
\hline Notes & \multicolumn{2}{|c|}{ We included only the subgroup with COPD } \\
\hline \multicolumn{3}{|l|}{ Risk of bias } \\
\hline Bias & Authors' judgement & Support for judgement \\
\hline $\begin{array}{l}\text { Random sequence generation (selection } \\
\text { bias) }\end{array}$ & Low risk & List of random numbers \\
\hline Allocation concealment (selection bias) & Low risk & Hospital pharmacist had the code of allocation \\
\hline $\begin{array}{l}\text { Blinding of participants and personnel } \\
\text { (performance bias) } \\
\text { All outcomes }\end{array}$ & Low risk & "Double blind" \\
\hline $\begin{array}{l}\text { Blinding of outcome assessment (detection } \\
\text { bias) } \\
\text { All outcomes }\end{array}$ & Unclear risk & Not reported \\
\hline Intention-to-treat-analysis & Low risk & Analysed as intention to treat \\
\hline
\end{tabular}

COPD: chronic obstructive pulmonary disease; $\mathrm{FEV}_{1}$ : forced expiratory volume in one second; FVC: forced vital capacity; ICU: intensive care unit; IV: intravenous; NYHA: New York Heart Association; PEFR: peak expiratory flow rate; RCT: randomised controlled trial; SD: standard deviation; SHO: senior house officer; TLC: total lung capacity; UTI: urinary tract infection.

Characteristics of excluded studies [ordered by study ID] 


\begin{tabular}{|c|c|}
\hline Study & Reason for exclusion \\
\hline Aitchison 1968 & No placebo group \\
\hline Alix 1979 & No placebo group \\
\hline Allan 1966 & No placebo group \\
\hline Allegra 1996 & No placebo group \\
\hline Alvarez-Sala 2006 & No placebo group \\
\hline Andrijevic 2011 & No comparison group \\
\hline Anon 1969 & No placebo group \\
\hline Anon 1972 & No placebo group \\
\hline Banerjee 2001 & No COPD exacerbations \\
\hline Bekçi 2009 & Participants did not have an exacerbation of COPD (stable patients) \\
\hline Bennion-Pedley 1969 & No placebo group \\
\hline Braendli 1982 & No placebo group \\
\hline Burgi 1975 & No placebo group \\
\hline Burrow 1975 & No placebo group \\
\hline Chatterjee 2011 & No placebo group \\
\hline Chen 2000 & No placebo group \\
\hline Christiansen 1963 & No placebo group \\
\hline Citron 1969 & Not an RCT \\
\hline Dong 2005 & No placebo group \\
\hline Douglas 1957 & Not randomised and study had no placebo group \\
\hline Egede 1993 & No placebo group \\
\hline Elmes 1965 & Not randomised. Matched pairs \\
\hline Fartoukh 2004 & Protocol. Trial stopped due to recruitment problems \\
\hline
\end{tabular}


(Continued)

\begin{tabular}{|c|c|}
\hline Filipovic 2000 & No placebo group \\
\hline Francis 1960 & Use of long-term prophylactic antibiotics \\
\hline Francis 1964 & No placebo group \\
\hline Fruensgaard 1972 & No placebo group \\
\hline Gaillat 2007 & No placebo group \\
\hline Gocke 1964 & No placebo group \\
\hline Goddard 2003 & Not an RCT \\
\hline Gomez 2000 & $\begin{array}{l}\text { Prophylactic antibiotic use. Patients treated with azithromycin } 500 \mathrm{mg} / \text { day for } 3 \text { days every } 21 \text { days during } \\
\text { the winter months, and a control group without treatment }\end{array}$ \\
\hline Gotfried 2007 & No placebo group \\
\hline Guerin 1987 & No placebo group \\
\hline Haanaes 1980 & No placebo group \\
\hline Hansen 1986 & Not an RCT \\
\hline Hansen 1990 & No clinical outcomes \\
\hline Hauke 2002 & No placebo group \\
\hline Hopkins 1962 & No placebo group \\
\hline Jacobsen 2002 & Not an RCT but a retrospective chart review \\
\hline Jia 2010 & No placebo group \\
\hline Johnston 1961 & Study assessed outcomes of long-term antibiotic use in stable patients (no exacerbation) \\
\hline Kaul 1967 & No placebo group \\
\hline King 1996 & Study not in patients with COPD but in patients with acute bronchitis \\
\hline Leophonte 1998 & Study not in patients with COPD but in patients with acute bronchitis \\
\hline Lirsac 2000 & $\begin{array}{l}\text { No placebo group. In addition the antibiotic treatment group also received fenspiride (from day } 0 \text { to day } \\
30 \text { ) and the control group received a placebo }\end{array}$ \\
\hline Maesen 1976 & No placebo group \\
\hline
\end{tabular}


(Continued)

\begin{tabular}{|c|c|}
\hline Maesen 1980 & No placebo group \\
\hline Malone 1968 & No placebo group \\
\hline May 1964 & No placebo group \\
\hline Miravitlles 2009 & Study compared participants with stable disease (no exacerbation) \\
\hline NCT00255983 & This study terminated early (financial reasons) \\
\hline Nicotra 1982 & No clinical outcomes \\
\hline Nonikov 2001 & No placebo group \\
\hline Parnham 2005 & Study looked at participants with stable disease (no exacerbation) \\
\hline Peng 2003 & Not an RCT but a retrospective cohort study \\
\hline Pham 1964 & Not an RCT \\
\hline Pines 1967 & No placebo group \\
\hline Pines 1969 & No placebo group \\
\hline Pines $1972 \mathrm{a}$ & No placebo group \\
\hline Pines 1973 & No placebo group \\
\hline Pines $1973 \mathrm{a}$ & No placebo group \\
\hline Pines 1974 & Not an RCT \\
\hline PRITZL 1959 & Not an RCT \\
\hline Puchelle 1975 & No placebo group \\
\hline Pugh 1964 & No placebo group \\
\hline Rethly 1961 & Not an RCT \\
\hline Roede 2007 & Placebo group began after 3 days of antibiotics in both groups \\
\hline Romanovskikh 2007 & No placebo group \\
\hline Ross 1973 & No placebo group \\
\hline Sethi 2007 & No placebo group \\
\hline
\end{tabular}


(Continued)

\begin{tabular}{|c|c|}
\hline Sethi 2010 & Study looked at participants with stable disease (no exacerbation) \\
\hline Smyllie 1972 & No placebo group \\
\hline Sohy 2002 & Not an RCT but a narrative review \\
\hline Soler 2003 & No placebo group \\
\hline Stolz 2007 & No placebo group \\
\hline Suzuki 2001 & Prophylactic antibiotic use \\
\hline Tremolieres 2000 & No placebo group \\
\hline Williams 1981 & No placebo group \\
\hline Wilson 2004 & No placebo group in trial. Moxifloxacin was compared to standard antibiotic therapy \\
\hline Wilson 2011 & No placebo group \\
\hline Wilson 2012 & Head-to-head trial of 2 different antibiotics regimens \\
\hline Zapulla 1988 & No placebo group \\
\hline Zervos 2005 & No placebo group \\
\hline
\end{tabular}

COPD: chronic obstructive pulmonary disease; RCT: randomised controlled trial.

\section{Characteristics of ongoing studies [ordered by study ID]}

\section{NCT01091493}

Trial name or title Utility of Antibiotic Treatment in Non-purulent Exacerbations of Chronic Obstructive Pulmonary Disease: a Double Blinded, Randomized, Placebo-controlled Trial of Security and Efficacy (AEPOC-ATB)

\begin{tabular}{ll}
\hline Methods & RCT \\
\hline Participants & $\begin{array}{l}\text { Inclusion criteria: aged } 40 \text { to } 90 \text { years; COPD diagnosis according to GOLD guidelines; hospitalisation for } \\
\text { any acute exacerbation of COPD; failure of outpatient treatment, increasing dyspnoea in the previous days; } \\
\text { co-morbidity that caused detriment of respiratory function }\end{array}$ \\
$\begin{array}{l}\text { Exclusion criteria: life expectancy of < } 6 \text { months; mechanical ventilation; cardiovascular condition that causes } \\
\text { exacerbation; immunosuppression; pulmonary infiltrates that suggest pneumonia; antibiotic treatment in the } \\
\text { last month; pregnancy; ECG with a large QT segment; hypokalaemia; hepatic failure or renal failure }\end{array}$
\end{tabular}




\section{NCT01091493 (Continued)}

\begin{tabular}{ll}
\hline Interventions & $\begin{array}{l}\text { Drug: moxifloxacin } 400 \text { mg administered once a day for } 5 \text { days } \\
\text { Control: no intervention }\end{array}$ \\
\hline Outcomes & $\begin{array}{l}\text { Primary outcome measures: efficacy of treatment WITHOUT antibiotics in non-purulent exacerbations of } \\
\text { COPD (time frame: } 6 \text { months) } \\
\text { Secondary outcome measures: efficacy/safety in treatment on re-hospitalisations at } 6 \text { months (time frame: } 6 \\
\text { months); in-hospital stay (days) (time frame: } 6 \text { months); all-cause mortality (time frame: } 1 \text { and } 6 \text { months) } \\
\text {; determination of procalcitonin (time frame: hospitalisation day 1, } 1 \text { month and } 6 \text { months); quality of life } \\
\text { measured by the St George's Respiratory Questionnaire (time frame: hospitalisation day } 1 \text { and } 6 \text { months); } \\
\text { measure of CRP (time frame: hospitalisation day } 1,1 \text { month and } 6 \text { months); measure of cytokines (IL-1, IL- } \\
\text { 6, IL-8, IL-10) (time frame: hospitalisation day } 1,1 \text { month and } 6 \text { months); measure of TNF- } \alpha \text { (time frame: } \\
\text { hospitalisation day 1, } 1 \text { month and } 6 \text { months) }\end{array}$ \\
\hline Starting date & July 2010 \\
\hline Contact information & Nestor Soler, M.D., Ph.D. email:nsoler@clinic.ub.es \\
\hline Notes & - \\
\hline
\end{tabular}

COPD: chronic obstructive pulmonary disease; CRP: C-reactive protein; ECG: electrocardiogram; IL: interleukin; RCT: randomised controlled trial; TNF- $\alpha$ : tumour necrosis factor-alpha. 
DATA AND ANALYSES

Comparison 1. Antibiotics versus placebo

\begin{tabular}{|c|c|c|c|c|}
\hline Outcome or subgroup title & $\begin{array}{l}\text { No. of } \\
\text { studies }\end{array}$ & $\begin{array}{c}\text { No. of } \\
\text { participants }\end{array}$ & Statistical method & Effect size \\
\hline $\begin{array}{l}1 \text { Treatment failure up to } 4 \text { weeks } \\
\text { (no resolution or deterioration } \\
\text { after trial medication of any } \\
\text { duration or death when } \\
\text { explicitly stated due to } \\
\text { exacerbation or additional } \\
\text { course of antibiotics) }\end{array}$ & 12 & 1636 & Risk Ratio (M-H, Fixed, 95\% CI) & $0.71[0.62,0.81]$ \\
\hline 1.1 Outpatient & 7 & 931 & Risk Ratio (M-H, Fixed, 95\% CI) & $0.75[0.60,0.94]$ \\
\hline 1.2 Inpatient & 4 & 612 & Risk Ratio (M-H, Fixed, 95\% CI) & $0.77[0.65,0.91]$ \\
\hline $1.3 \mathrm{ICU}$ & 1 & 93 & Risk Ratio (M-H, Fixed, 95\% CI) & $0.19[0.08,0.45]$ \\
\hline $\begin{array}{l}2 \text { Treatment failure within } 4 \text { weeks } \\
\text { - current drugs only }\end{array}$ & 8 & 1175 & Risk Ratio (M-H, Fixed, 95\% CI) & $0.76[0.64,0.91]$ \\
\hline 2.1 Outpatient & 5 & 790 & Risk Ratio (M-H, Fixed, 95\% CI) & $0.80[0.63,1.01]$ \\
\hline 2.2 Inpatient & 3 & 385 & Risk Ratio (M-H, Fixed, 95\% CI) & $0.71[0.55,0.92]$ \\
\hline 3 Adverse events & 5 & & Peto Odds Ratio (Peto, Fixed, 95\% CI) & Subtotals only \\
\hline 3.1 Diarrhoea & 3 & 698 & Peto Odds Ratio (Peto, Fixed, 95\% CI) & $2.62[1.11,6.17]$ \\
\hline 3.2 Dyspepsia & 2 & 605 & Peto Odds Ratio (Peto, Fixed, 95\% CI) & $0.69[0.28,1.73]$ \\
\hline 3.3 Pain in mouth & 1 & 270 & Peto Odds Ratio (Peto, Fixed, 95\% CI) & $7.73[0.80,74.98]$ \\
\hline 3.4 Exanthema, itching & 3 & 698 & Peto Odds Ratio (Peto, Fixed, 95\% CI) & $3.83[0.77,19.11]$ \\
\hline $\begin{array}{l}3.5 \text { Overall (adverse events } \\
\text { not separated) }\end{array}$ & 5 & 1243 & Peto Odds Ratio (Peto, Fixed, 95\% CI) & $1.53[1.03,2.27]$ \\
\hline 4 All-cause mortality & 5 & 624 & Peto Odds Ratio (Peto, Fixed, 95\% CI) & $0.54[0.25,1.16]$ \\
\hline 4.1 Inpatients & 4 & 531 & Peto Odds Ratio (Peto, Fixed, 95\% CI) & $1.02[0.37,2.79]$ \\
\hline 4.2 ICU patients & 1 & 93 & Peto Odds Ratio (Peto, Fixed, 95\% CI) & $0.21[0.06,0.72]$ \\
\hline 5 Duration of hospital stay (days) & 3 & 202 & Mean Difference (IV, Random, 95\% CI) & $-3.04[-8.83,2.76]$ \\
\hline $\begin{array}{l}6 \text { Improvement in dyspnoea } \\
\text { measured at the end of the } \\
\text { study period }\end{array}$ & 2 & 300 & Mean Difference (IV, Fixed, 95\% CI) & $-0.40[-0.96,0.15]$ \\
\hline 6.1 Outpatients & 1 & 35 & Mean Difference (IV, Fixed, 95\% CI) & $0.0[-0.97,0.97]$ \\
\hline 6.2 Inpatients & 1 & 265 & Mean Difference (IV, Fixed, 95\% CI) & $-0.60[-1.27,0.07]$ \\
\hline $\begin{array}{l}7 \text { Health-related quality of life or } \\
\text { functional status measures }\end{array}$ & 1 & & Mean Difference (IV, Fixed, 95\% CI) & Totals not selected \\
\hline $\begin{array}{l}8 \text { Re-exacerbations within } \geq 2 \\
\text { to } 6 \text { weeks since beginning of } \\
\text { index exacerbation (rates) }\end{array}$ & 1 & & Risk Ratio (M-H, Fixed, 95\% CI) & Totals not selected \\
\hline 9 Days off work & 1 & 88 & Mean Difference (IV, Fixed, 95\% CI) & $-5.18[-6.08,-4.28]$ \\
\hline
\end{tabular}

Antibiotics for exacerbations of chronic obstructive pulmonary disease (Review) 
Analysis I.I. Comparison I Antibiotics versus placebo, Outcome I Treatment failure up to 4 weeks (no resolution or deterioration after trial medication of any duration or death when explicitly stated due to exacerbation or additional course of antibiotics).

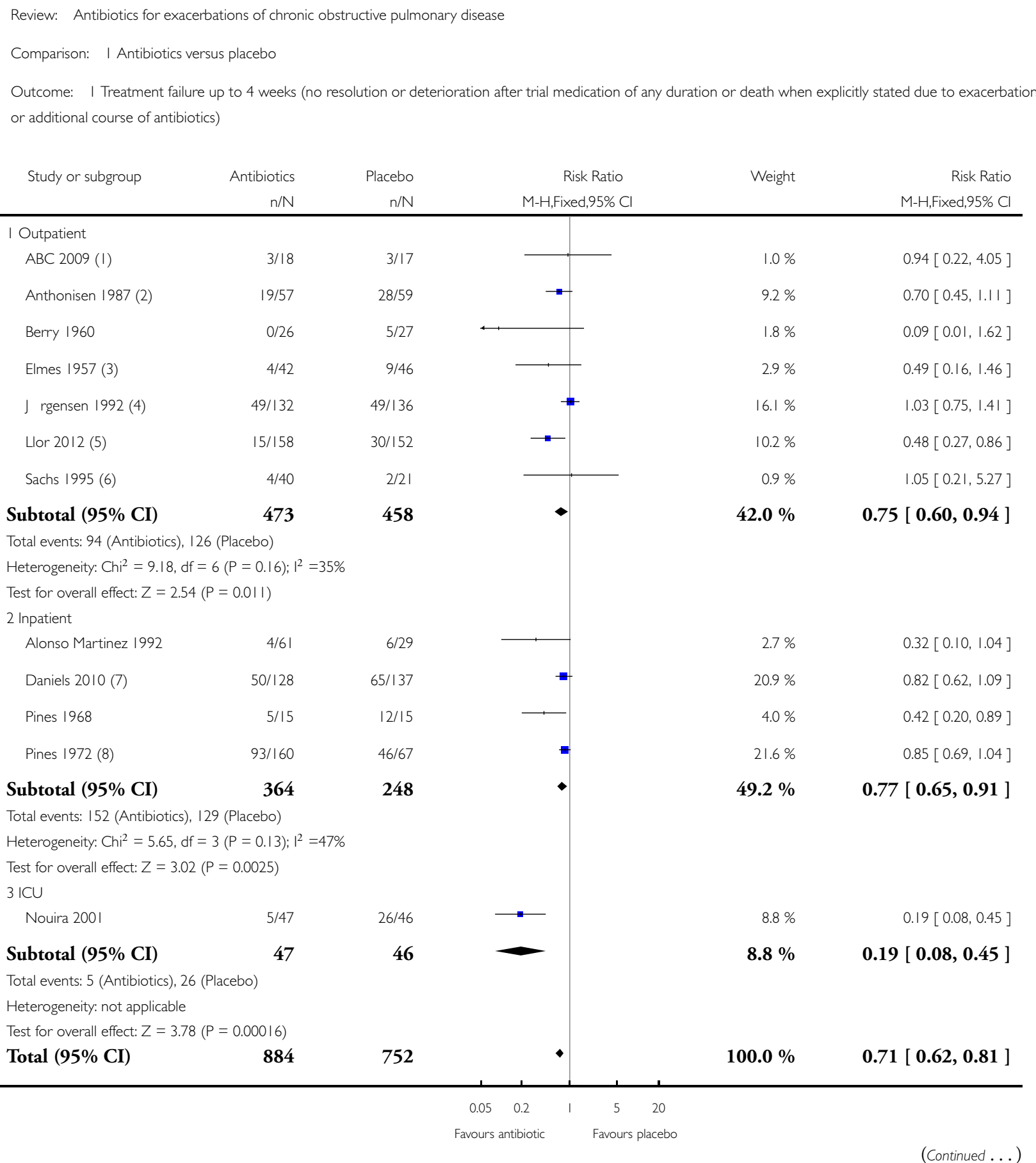


Total events: 25I (Antibiotics), 28 I (Placebo)

Heterogeneity: $\mathrm{Chi}^{2}=26.34, \mathrm{df}=\mathrm{II}(\mathrm{P}=0.0 \mathrm{I}) ; \mathrm{I}^{2}=58 \%$

Test for overall effect: $Z=4.95(P<0.0000 \mathrm{I})$

Test for subgroup differences: $\mathrm{Chi}^{2}=9.85, \mathrm{df}=2(\mathrm{P}=0.0 \mathrm{I}), \mathrm{I}^{2}=80 \%$

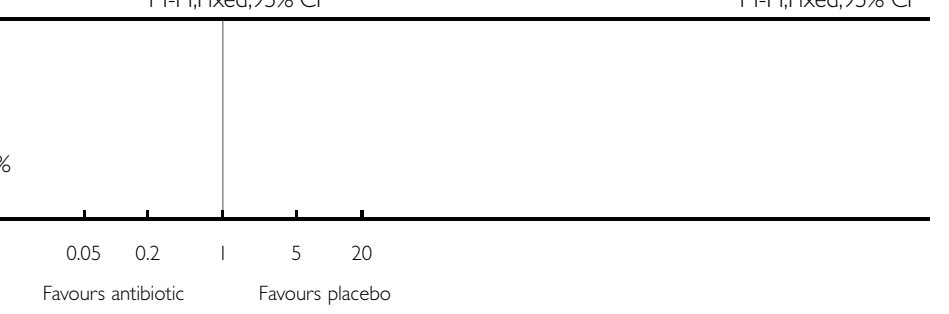
( 1 ) 28 days,
(2) within 21 days
(3) time point unclear;reported for exacerbations only.under the assumption that it happened to every pat once we took patients instead
(4) day 8
(5) 20 days
(6) failure between 4-24 days
(7) day 30
(8) additional antibiotics (day 7-28) 
Analysis I.2. Comparison I Antibiotics versus placebo, Outcome 2 Treatment failure within 4 weeks current drugs only.

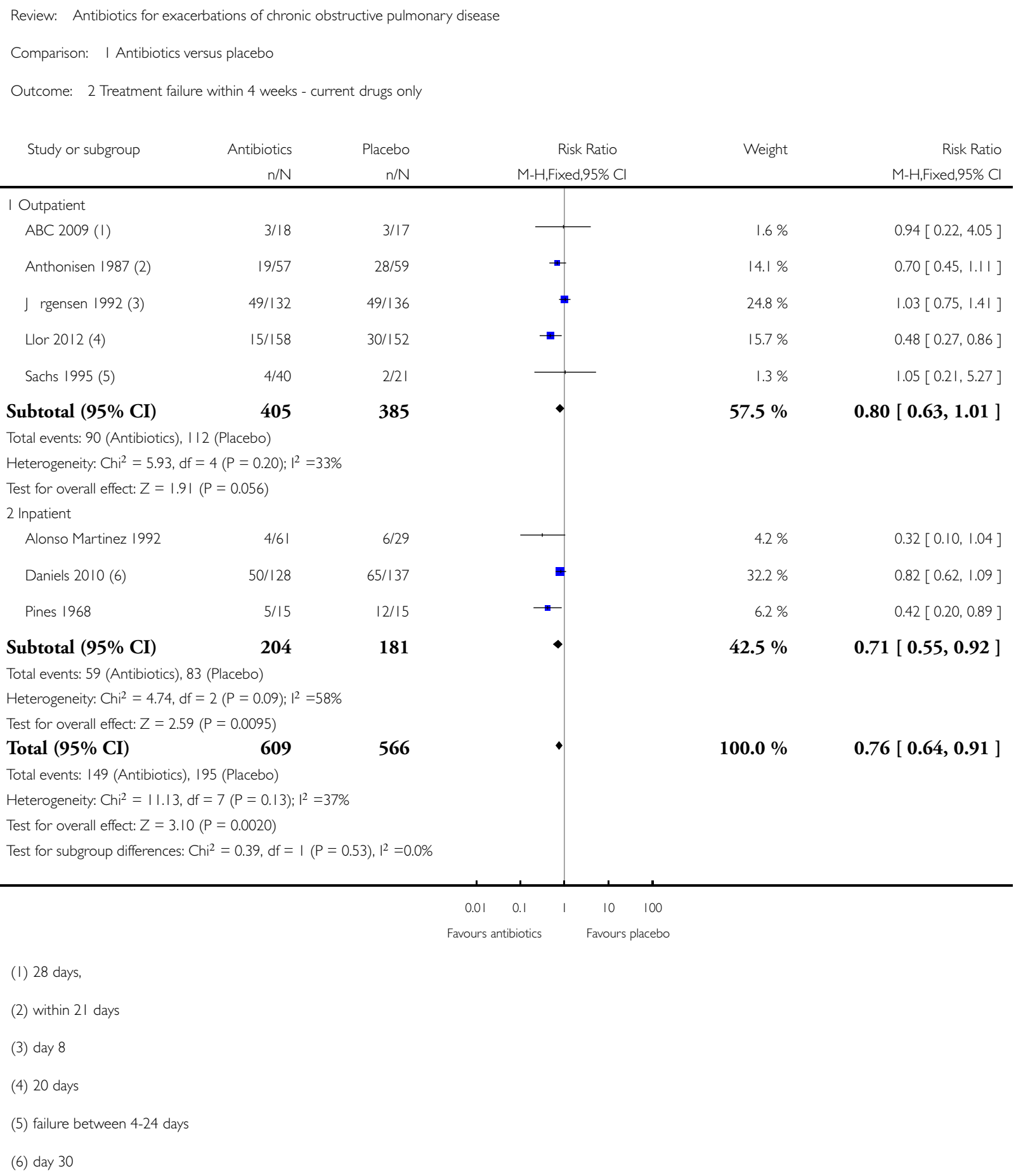




\section{Analysis I.3. Comparison I Antibiotics versus placebo, Outcome 3 Adverse events.}

Review: Antibiotics for exacerbations of chronic obstructive pulmonary disease

Comparison: I Antibiotics versus placebo

Outcome: 3 Adverse events

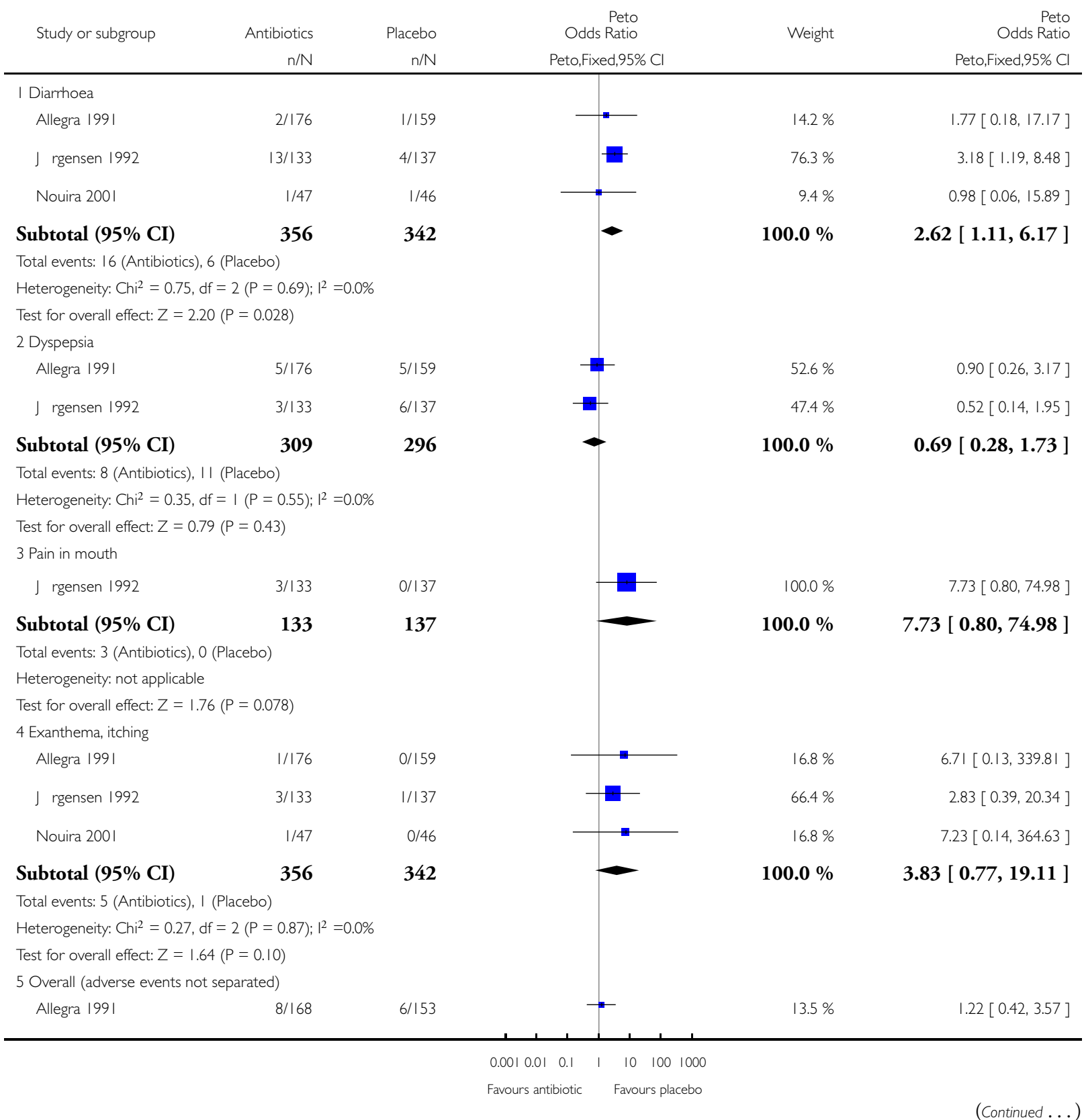

Antibiotics for exacerbations of chronic obstructive pulmonary disease (Review) 


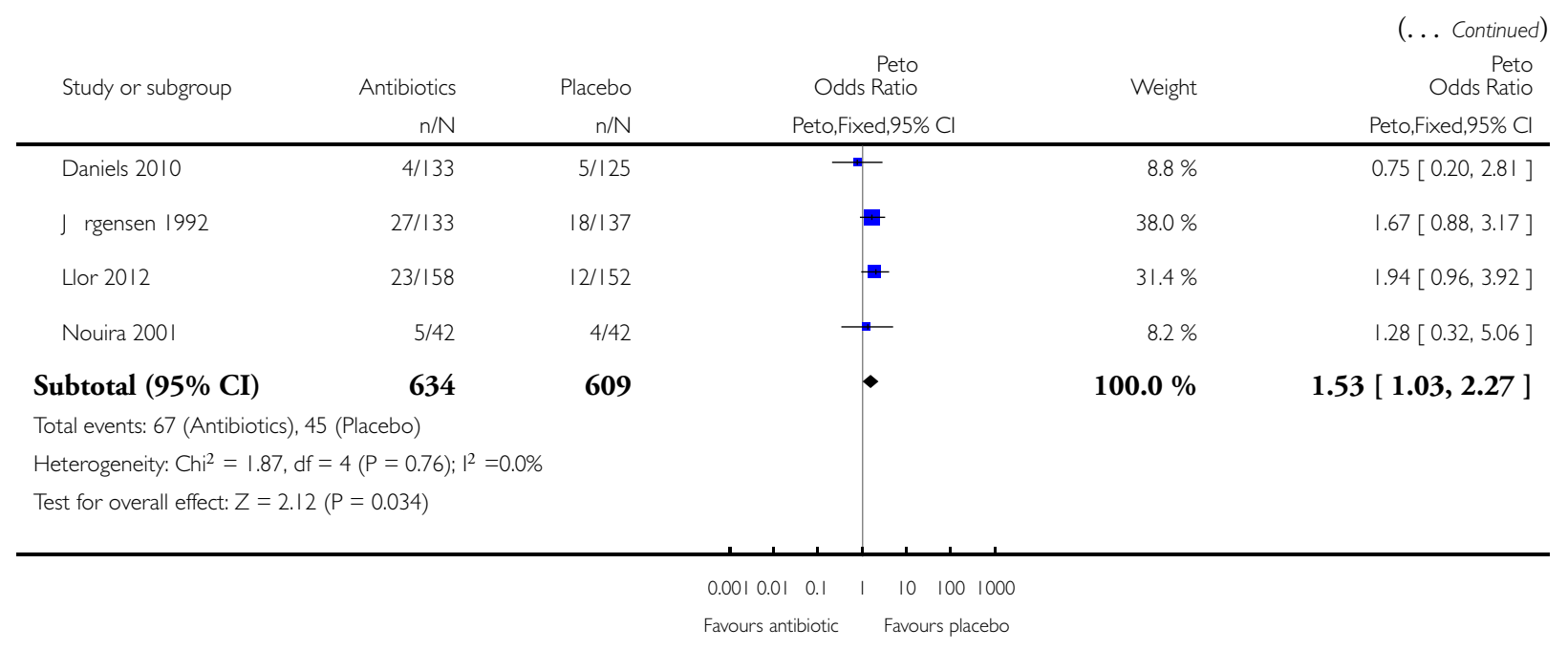

\section{Analysis I.4. Comparison I Antibiotics versus placebo, Outcome 4 All-cause mortality.}

Review: Antibiotics for exacerbations of chronic obstructive pulmonary disease

Comparison: I Antibiotics versus placebo

Outcome: 4 All-cause mortality

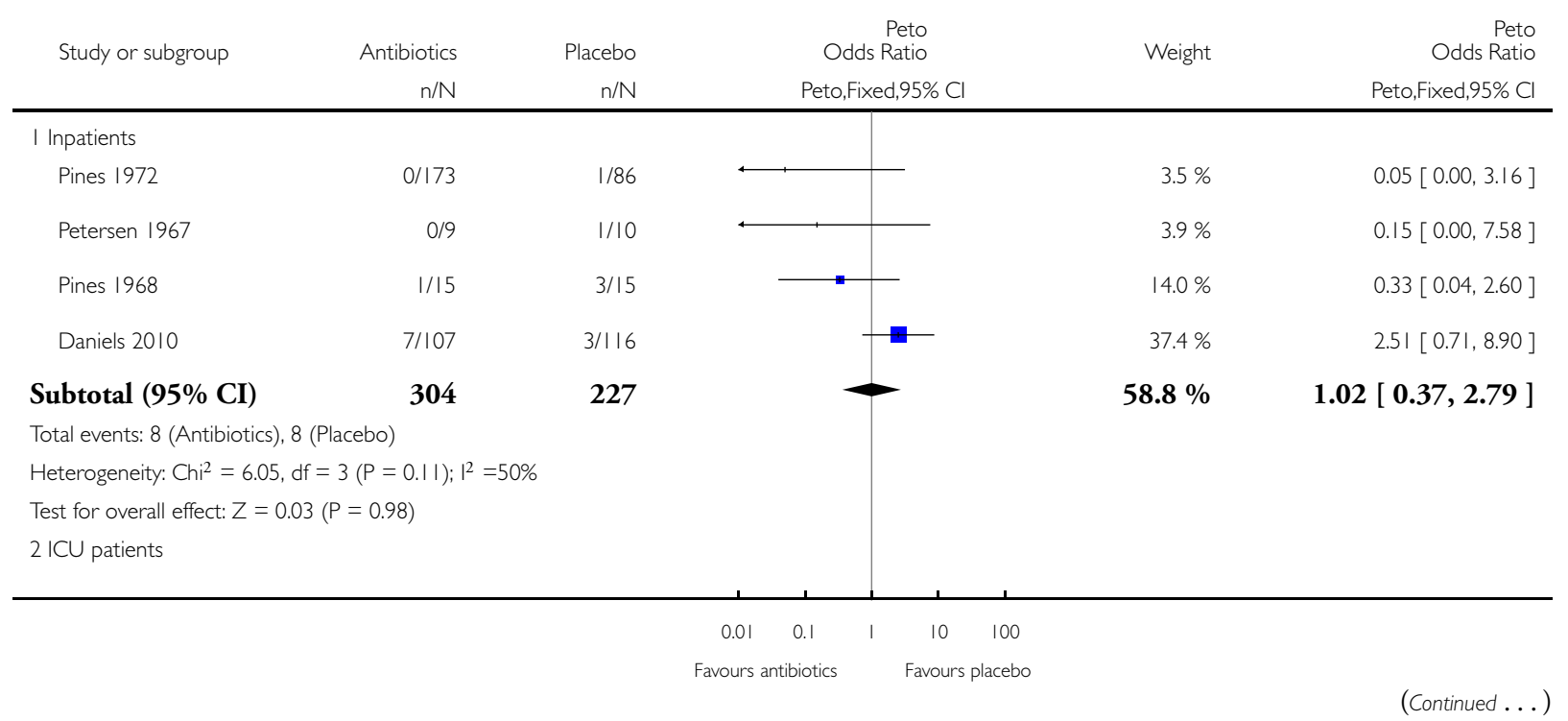

Antibiotics for exacerbations of chronic obstructive pulmonary disease (Review) 


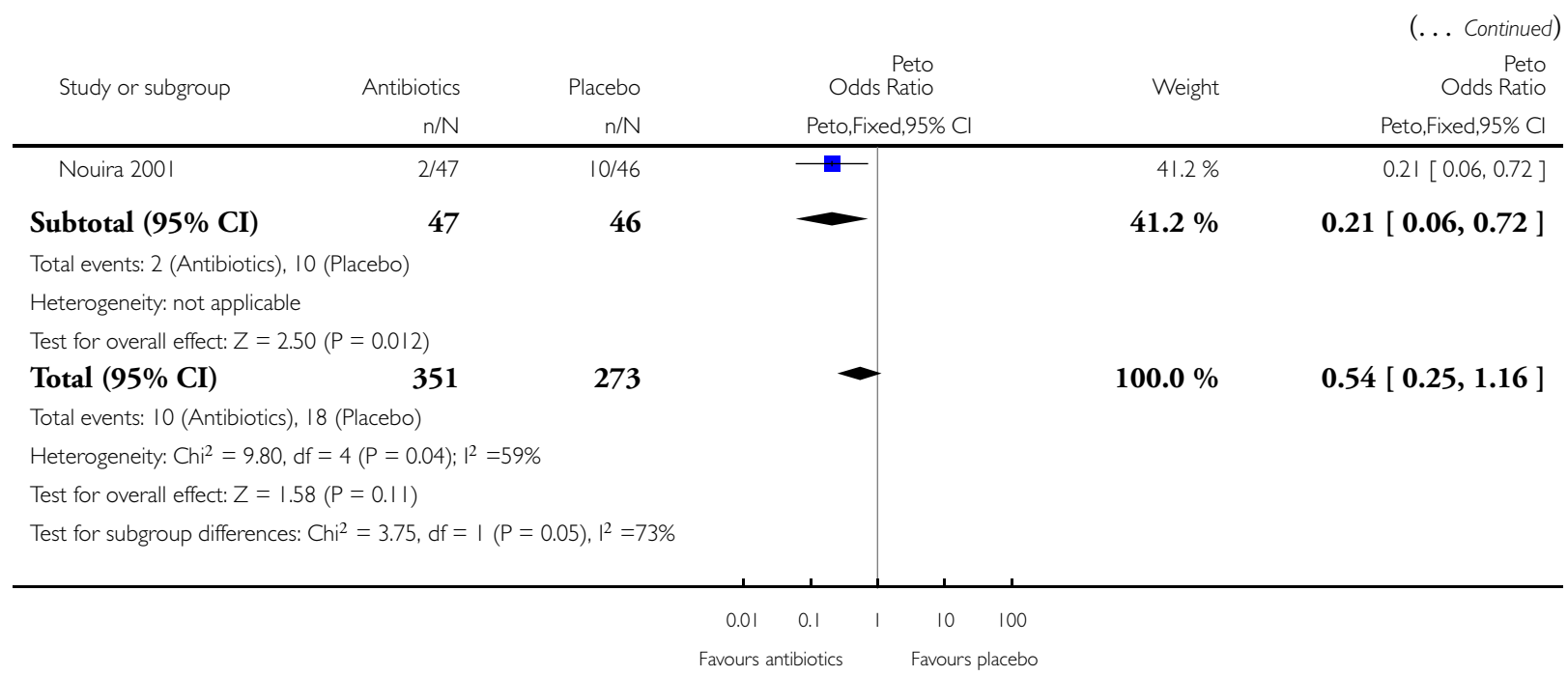

\section{Analysis I.5. Comparison I Antibiotics versus placebo, Outcome 5 Duration of hospital stay (days).}

Review: Antibiotics for exacerbations of chronic obstructive pulmonary disease

Comparison: I Antibiotics versus placebo

Outcome: 5 Duration of hospital stay (days)

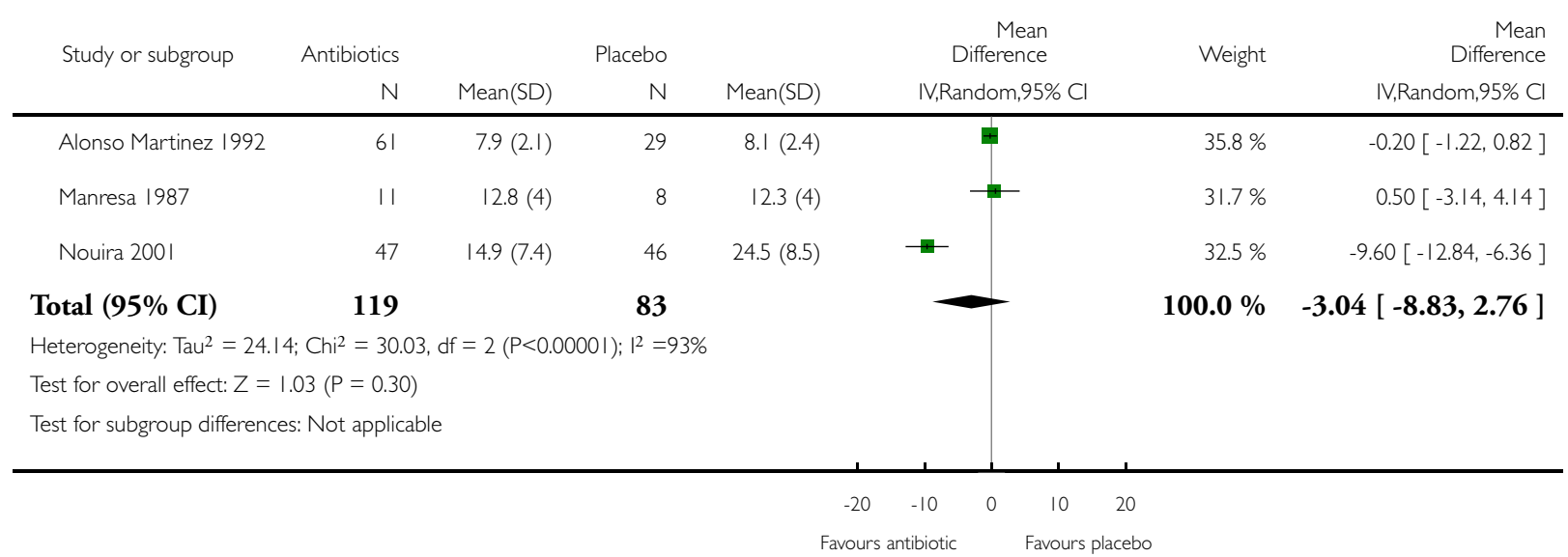


Analysis I.6. Comparison I Antibiotics versus placebo, Outcome 6 Improvement in dyspnoea measured at the end of the study period.

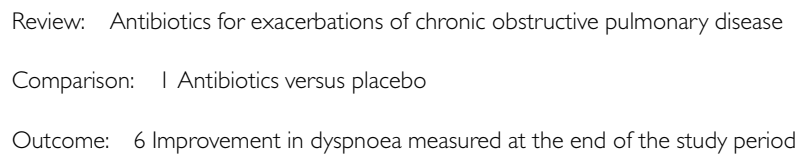

\begin{tabular}{|c|c|c|c|c|c|c|c|}
\hline \multirow[t]{2}{*}{ Study or subgroup } & \multirow{2}{*}{$\begin{array}{r}\text { Antibiotics } \\
N\end{array}$} & \multicolumn{3}{|c|}{ Placebo } & \multirow{2}{*}{$\begin{array}{c}\text { Mean } \\
\text { Difference } \\
\text { IV,Fixed,95\% Cl }\end{array}$} & \multirow[t]{2}{*}{ Weight } & \multirow{2}{*}{$\begin{array}{r}\text { Mean } \\
\text { Difference } \\
\text { IV,Fixed,95\% C }\end{array}$} \\
\hline & & Mean(SD) & $\mathrm{N}$ & Mean(SD) & & & \\
\hline \multicolumn{8}{|l|}{ I Outpatients } \\
\hline ABC 2009 & 18 & $0.5(1.3)$ & 17 & $0.5(1.6)$ & 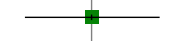 & $32.6 \%$ & $0.0[-0.97,0.97]$ \\
\hline Subtotal (95\% CI) & 18 & & 17 & & & $32.6 \%$ & $0.0[-0.97,0.97]$ \\
\hline \multicolumn{8}{|c|}{ Heterogeneity: not applicable } \\
\hline \multicolumn{8}{|c|}{ Test for overall effect: $Z=0.0(P=1.0)$} \\
\hline \multicolumn{8}{|l|}{2 Inpatients } \\
\hline Daniels 2010 & 128 & $-2.4(2.8)$ & 137 & $-1.8(2.8)$ & & $67.4 \%$ & $-0.60[-1.27,0.07]$ \\
\hline Subtotal (95\% CI) & 128 & & 137 & & & $67.4 \%$ & $-0.60[-1.27,0.07]$ \\
\hline \multicolumn{8}{|c|}{ Heterogeneity: not applicable } \\
\hline \multicolumn{8}{|c|}{ Test for overall effect: $Z=1.74(P=0.081)$} \\
\hline Total (95\% CI) & 146 & & 154 & & & $100.0 \%$ & $-0.40[-0.96,0.15]$ \\
\hline \multicolumn{8}{|c|}{ Heterogeneity: Chi $^{2}=0.99, d f=I(P=0.32) ;\left.\right|^{2}=0.0 \%$} \\
\hline \multicolumn{8}{|c|}{ Test for overall effect: $Z=1.43(P=0.15)$} \\
\hline \multicolumn{8}{|c|}{ Test for subgroup differences: $\mathrm{Chi}^{2}=0.99, \mathrm{df}=\mathrm{I}(\mathrm{P}=0.32), \mathrm{I}^{2}=0.0 \%$} \\
\hline & & & & -2 & -1 & 2 & \\
\hline & & & & Favours & Favour & ontrol & \\
\hline
\end{tabular}


Analysis I.7. Comparison I Antibiotics versus placebo, Outcome 7 Health-related quality of life or functional status measures.

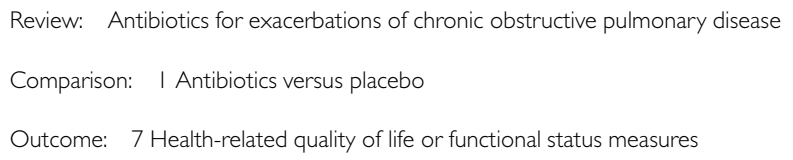

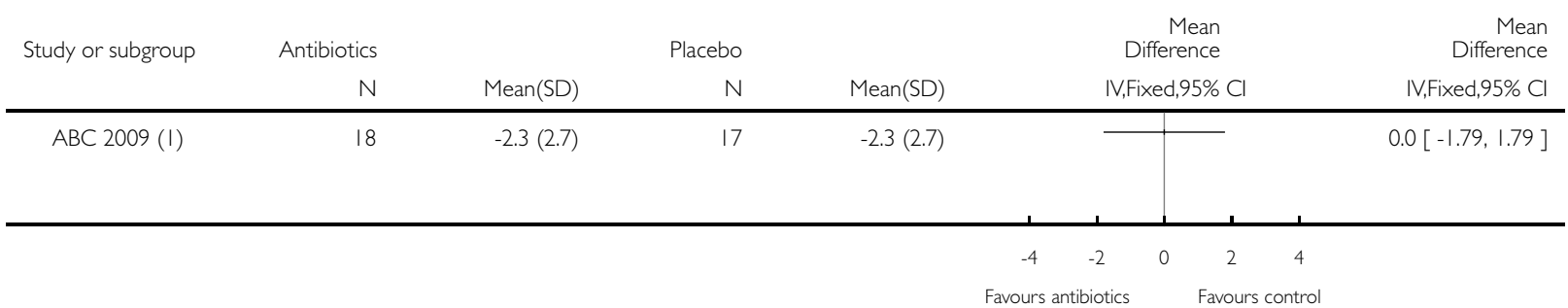

( I) CCQ

\section{Analysis I.8. Comparison I Antibiotics versus placebo, Outcome 8 Re-exacerbations within $\geq 2$ to 6 weeks} since beginning of index exacerbation (rates).

Review: Antibiotics for exacerbations of chronic obstructive pulmonary disease

Comparison: I Antibiotics versus placebo

Outcome: 8 Re-exacerbations within $\geq 2$ to 6 weeks since beginning of index exacerbation (rates)

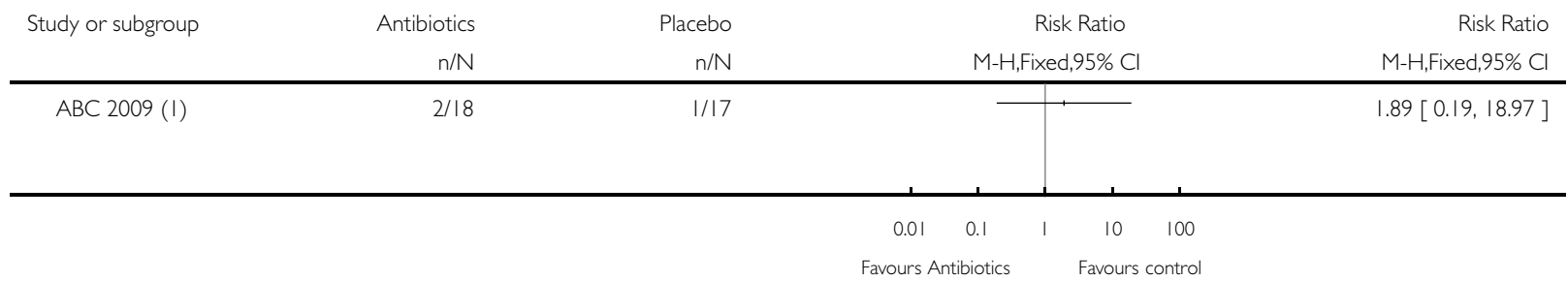

(I) relapse within 4 weeks 


\section{Analysis I.9. Comparison I Antibiotics versus placebo, Outcome 9 Days off work.}

Review: Antibiotics for exacerbations of chronic obstructive pulmonary disease

Comparison: I Antibiotics versus placebo

Outcome: 9 Days off work

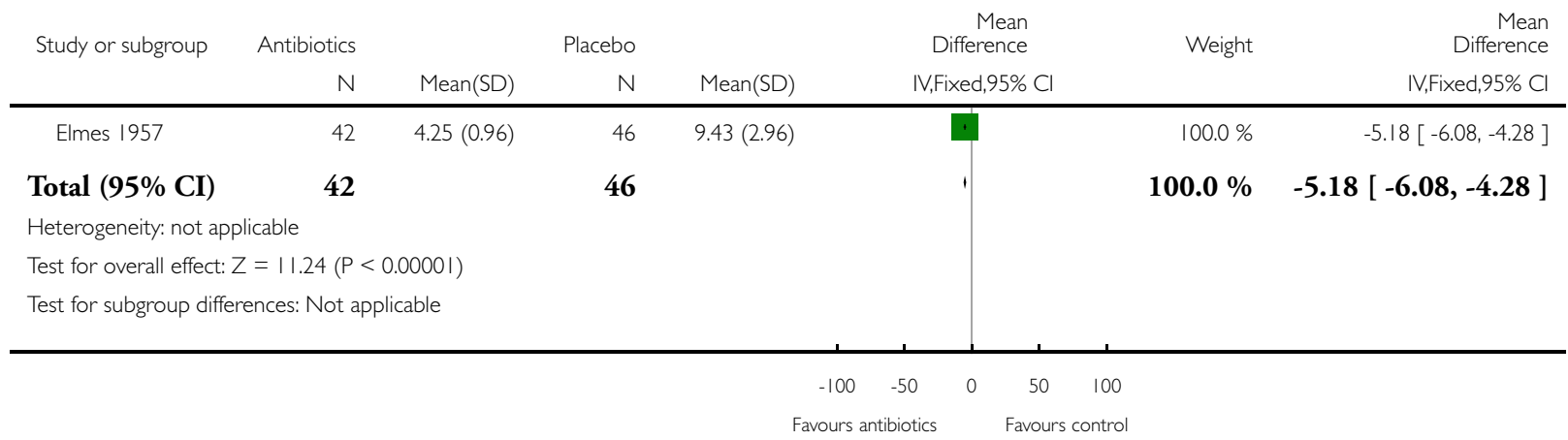

\section{ADDITIONAL TABLES}

Table 1. Type and dose of antibiotic used

\begin{tabular}{|c|c|c|c|c|c|c|}
\hline Study & Antibiotic & Dose & Duration & $\begin{array}{l}\text { Currently avail- } \\
\text { able and used? }\end{array}$ & Co-interventions & Control \\
\hline ABC 2009 & $\begin{array}{l}\text { Amoxicillin- } \\
\text { clavulanic acid } \\
\text { (oral) }\end{array}$ & $1.5 \mathrm{~g} /$ day & 7 days & Yes & $\begin{array}{l}\text { Oral prednisolone } \\
30 \mathrm{mg} \text { for } 7 \text { days }\end{array}$ & $\begin{array}{l}\text { Placebo for } 7 \\
\text { days and oral pred- } \\
\text { nisolone } 30 \mathrm{mg} \text { for } \\
7 \text { days }\end{array}$ \\
\hline Allegra 1991 & $\begin{array}{l}\text { Amoxicillin- } \\
\text { clavulanic acid } \\
\text { (oral) }\end{array}$ & $2 \mathrm{~g} /$ day & 5 days & Yes & & Placebo \\
\hline $\begin{array}{l}\text { Alonso Martinez } \\
1992\end{array}$ & $\begin{array}{l}\text { Trimethoprim- } \\
\text { sulphamethox- } \\
\text { azole or amoxi- } \\
\text { cillin/clavulanic } \\
\text { acid }\end{array}$ & $1.9 \mathrm{~g} /$ day & 8 days & Yes & & \\
\hline $\begin{array}{l}\text { Anthonisen } \\
1987\end{array}$ & $\begin{array}{l}\text { Trimethoprim/ } \\
\text { sulphamethoxa- } \\
\text { zole (oral) }\end{array}$ & $1.9 \mathrm{~g} /$ day & 10 days & Yes & & Placebo \\
\hline
\end{tabular}


Table 1. Type and dose of antibiotic used (Continued)

\begin{tabular}{|c|c|c|c|c|c|c|}
\hline & \multicolumn{2}{|l|}{$\begin{array}{l}\text { Amoxicillin } \\
\text { (oral) }\end{array}$} & $1 \mathrm{~g} /$ day & & & \\
\hline & $\begin{array}{l}\text { Doxycycline } \\
\text { (oral) }\end{array}$ & 0.1 to $0.2 /$ day & & & & \\
\hline Berry 1960 & $\begin{array}{l}\text { Oxytetracycline } \\
\text { (oral) }\end{array}$ & $1 \mathrm{~g} / \mathrm{day}$ & 5 days & No & & Placebo \\
\hline Daniels 2010 & $\begin{array}{l}\text { Doxycycline } \\
\text { (oral) }\end{array}$ & & 7 days & Yes & $\begin{array}{l}\text { IV prednisolone ta- } \\
\text { per }\end{array}$ & $\begin{array}{l}\text { Placebo plus IV } \\
\text { prednisolone taper }\end{array}$ \\
\hline Elmes 1957 & $\begin{array}{l}\text { Oxytetracycline } \\
\text { (oral) }\end{array}$ & $1 \mathrm{~g} /$ day & 5 to 7 days & No & & Placebo \\
\hline Fear 1962 & $\begin{array}{l}\text { Oxytetracycline } \\
\text { (oral) }\end{array}$ & $1 \mathrm{~g} /$ day & 7 days & No & & placebo \\
\hline Jørgensen 1992 & $\begin{array}{l}\text { Amoxicillin } \\
\text { (oral) }\end{array}$ & $1.5 \mathrm{~g} /$ day & 7 days & Yes & & placebo \\
\hline Llor 2012 & $\begin{array}{l}\text { Amoxicillin/ } \\
\text { clavulanate } \\
\text { (oral) }\end{array}$ & $1.5 \mathrm{~g} /$ day & 8 days & Yes & & Placebo \\
\hline Manresa 1987 & Cefaclor (oral) & $1.5 \mathrm{~g} /$ day & 8 days & Yes & & placebo \\
\hline Nouira 2001 & Ofloxacin (oral) & $400 \mathrm{mg} /$ day & 10 days & Yes & & placebo \\
\hline Petersen 1967 & $\begin{array}{l}\text { Chlorampheni- } \\
\text { col (oral) }\end{array}$ & $2 \mathrm{~g} /$ day & 10 days & No & & placebo \\
\hline Pines 1968 & $\begin{array}{l}\text { Penicillin } \\
\text { (parenterally) }\end{array}$ & $1 \mathrm{~g} /$ day & 14 days & Yes & & placebo \\
\hline Pines 1972 & $\begin{array}{l}\text { Tetracycline hy- } \\
\text { drochloride } \\
\text { (oral) or Chlo- } \\
\text { ramphenicol }\end{array}$ & $2 \mathrm{~g} /$ day & 12 days & No & & placebo \\
\hline \multirow[t]{2}{*}{ Sachs 1995} & $\begin{array}{l}\text { Amoxicillin } 1.5 \\
\text { g/day } 1.9 \mathrm{~g} / \text { day } \\
\text { (oral) }\end{array}$ & $1.5 \mathrm{~g} / \mathrm{day}$ & \multirow[t]{2}{*}{7 days } & \multirow[t]{2}{*}{ yes } & & \multirow[t]{2}{*}{ placebo } \\
\hline & $\begin{array}{l}\text { or } \\
\text { trimoxazole }\end{array}$ & $1.9 \mathrm{~g} /$ day & & & & \\
\hline
\end{tabular}

TV: intravenous. 
A P PENDICES

\section{Appendix I. Sources and search methods for the Cochrane Airways Group Specialised Register (CAGR)}

\section{Electronic searches: core databases}

\begin{tabular}{ll}
\hline Database & Frequency of search \\
\hline CENTRAL (T he Cochrane Library) & Monthly \\
\hline MEDLINE (Ovid) & Weekly \\
\hline EMBASE (Ovid) & Weekly \\
\hline PsycINFO (Ovid) & Monthly \\
\hline CINAHL (EBSCO) & Monthly \\
\hline AMED (EBSCO) & Monthly \\
\hline
\end{tabular}

Handsearches: core respiratory conference abstracts

\begin{tabular}{l|l}
\hline Conference & Years searched \\
\hline American Academy of Allergy, Asthma and Immunology (AAAAI) & 2001 onwards \\
\hline American Thoracic Society (ATS) & 2001 onwards \\
\hline Asia Pacific Society of Respirology (APSR) & 2004 onwards \\
\hline British Thoracic Society Winter Meeting (BTS) & 2000 onwards \\
\hline Chest Meeting & 2003 onwards \\
\hline European Respiratory Society (ERS) & $1992,1994,2000$ onwards \\
\hline International Primary Care Respiratory Group Congress (IPCRG) & 2002 onwards \\
\hline Thoracic Society of Australia and New Zealand (TSANZ) & 1999 onwards \\
\hline
\end{tabular}




\section{COPD search}

1. Lung Diseases, Obstructive/

2. exp Pulmonary Disease, Chronic Obstructive/

3. emphysema\$.mp.

4. (chronic $\$$ adj3 bronchiti $\$) . m p$.

5. (obstruct $\$$ adj3 (pulmonary or lung $\$$ or airway $\$$ or airflow $\$$ or bronch $\$$ or respirat $\$$ )).mp.

6. COPD.mp.

7. COAD.mp.

8. COBD.mp.

9. AECB.mp.

10. or/1-9

\section{Filter to identify RCTs}

1. exp "clinical trial [publication type]"/

2. (randomised or randomised).ab,ti.

3. placebo.ab,ti.

4. dt.fs.

5. randomly.ab,ti.

6. trial.ab,ti.

7. groups.ab,ti.

8. or/1-7

9. Animals/

10. Humans/

11. 9 not (9 and 10)

12. 8 not 11

The MEDLINE strategy and RCT filter are adapted to identify trials in other electronic databases

\section{CONTRIBUTIONSOFAUTHORS}

All authors conceived the idea for the review and wrote the protocol.

DV, HJ and CSS contributed towards the following: trial selection, data and trial characteristics extraction.

MAP, JGA, DV checked the data extraction.

DV and MAP contributed to trial grading.

DV wrote the first draft and all authors critically reviewed the draft.

$\mathrm{DV}$ and MP are the guarantors for this review. 


\section{DECLARATIONSOF INTEREST}

Claudia Steurer-Stey has lectured for the antibiotic-producing companies AstraZeneca, GlaxoWellcome, Merck Sharp \& Dome, Pfizer and Novartis. The remaining four authors (DV, HJ, JGA and MAP) do not have any known conflicts of interest.

\section{DIFFERENCES BETWEEN PROTOCOLANDREVIEW}

We had to change our primary outcome from treatment failure within two weeks to four weeks because the reporting of the time of the end point was too heterogeneous.

Some outcomes were not reported at all (hospital admission, admission to an ICU).

We did not analyse subgroups on duration of antibiotic intervention or type of antibiotic intervention because the number of studies was too small.

\section{NDEX TERMS \\ Medical Subject Headings (MeSH)}

Ambulatory Care; Anti-Bacterial Agents [adverse effects; *therapeutic use]; Disease Progression; Hospitalization; Intensive Care Units; Pulmonary Disease, Chronic Obstructive [classification; *drug therapy; mortality]; Randomized Controlled Trials as Topic; Treatment Failure

\section{MeSH check words}

Humans 